(2) norden 



\section{Nordic perspectives on the Gothenburg Protocol to Abate Acidification, Eutrophication and Ground-level Ozone}

Pedersen, Anders Branth, Jørgen Brandt, Thomas Ellermann, Lise Marie Frohn, Leif Hoffmann, Finn Palmgren and Mikael Skou Andersen 
Nordic perspectives on the Gothenburg Protocol to Abate Acidification, Eutrophication and Ground-level Ozone

TemaNord 2008:572

(C) Nordic Council of Ministers, Copenhagen 2008

ISBN 978-92-893-1730-6

Print: Ekspressen Tryk \& Kopicenter

Printed on environmentally friendly paper

This publication can be ordered on www.norden.org/order. Other Nordic publications are available at www.norden.org/publications

Printed in Denmark

\section{Nordic Council of Ministers}

Store Strandstræde 18

DK-1255 Copenhagen K

Phone (+45) 33960200

Fax (+45) 33960202

www.norden.org

\section{Nordic Council}

Store Strandstræde 18

DK-1255 Copenhagen K

Phone (+45) 33960400

Fax (+45) 33111870

\section{Nordic co-operation}

Nordic cooperation is one of the world's most extensive forms of regional collaboration, involving Denmark, Finland, Iceland, Norway, Sweden, and three autonomous areas: the Faroe Islands, Greenland, and Åland.

Nordic cooperation has firm traditions in politics, the economy, and culture. It plays an important rol in European and international collaboration, and aims at creating a strong Nordic community in a strong Europe.

Nordic cooperation seeks to safeguard Nordic and regional interests and principles in the global community. Common Nordic values help the region solidify its position as one of the world's most innovative and competitive. 


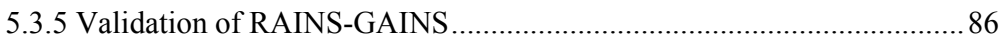

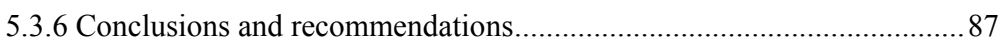

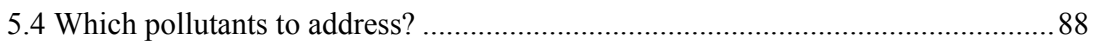

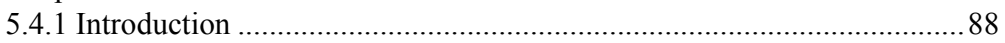

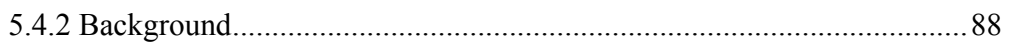

5.4.3 Recommendations for the new protocol .......................................... 89

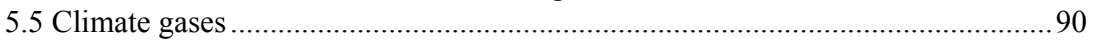

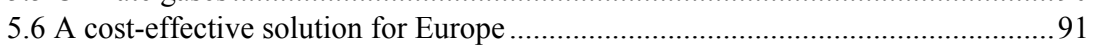

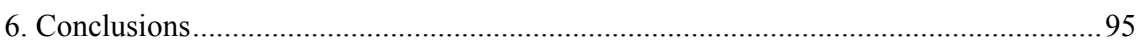

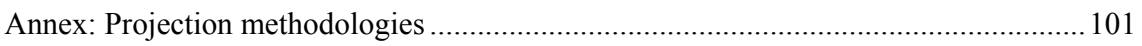

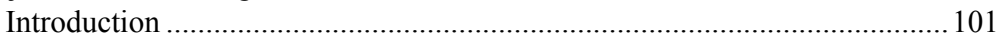

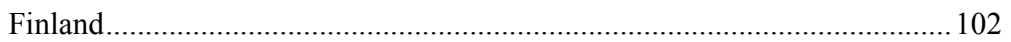

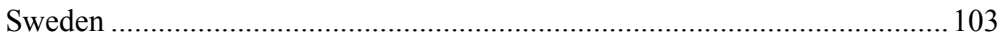

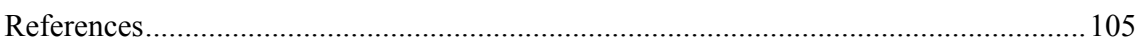

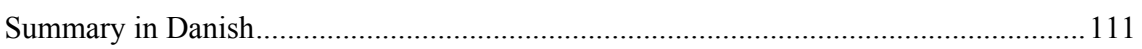




\section{Preface}

This report was prepared by the National Environmental Research Institute (NERI) at the University of Aarhus, Denmark. The project team comprised experts from the Department of Policy Analysis (Anders Branth Pedersen, Leif Hoffmann, Mikael Skou Andersen) and from the Department of Atmospheric Environment (Jørgen Brandt, Thomas Ellermann, Lise Marie Frohn and Finn Palmgren). We are grateful to AnnKatrine Holme Christoffersen for editorial assistance and to Carey Elizabeth Smith for linguistic proficiency.

The Nordic Council of Ministers and its Working Group on Environment and Finance is not directly accountable for the observations and conclusions of the report, but the authors gratefully acknowledge information and comments provided by members of the Working Group.

Århus and Roskilde, June 2008 



\section{Summary}

1. The 1999 Gothenburg Protocol aimed to close the gap between critical loads, as defined from a combined ecosystem and health perspective, and emissions of the four pollutants; $\mathrm{SO}_{2}, \mathrm{NO}_{\mathrm{X}}, \mathrm{NH}_{3}$ and VOC. To contribute to reductions in critical load exceedance, Nordic countries accepted emissions ceilings for $\mathrm{SO}_{2}$ and VOC that were stricter than those of the other protocol parties, while for $\mathrm{NO}_{\mathrm{X}}$ Nordic ceilings were at levels similar to those of European Union members. In the four Nordic countries that have signed the protocol, emissions of all four pollutants have shown a clear declining trend. While Iceland is not party to the protocol, it has similar domestic reduction targets to the other four, but Iceland has experienced increasing emissions of $\mathrm{SO}_{2}$ and $\mathrm{NO}_{\mathrm{X}}$.

2. The review in this report shows that according to the most recent and updated national projections, the relevant Nordic countries are on track for compliance with the majority of emissions ceilings of the Gothenburg Protocol. The gaps between projections and ceilings for 2010 with respect to $\mathrm{NO}_{\mathrm{X}}$, which were noted by the 2007 LRTAP CIAM assessment, have narrowed considerably. Still, according to current projections Norway, Sweden and Denmark will fall short of full compliance with $\mathrm{NO}_{\mathrm{X}}$ ceilings in 2010. Denmark will also fall short of compliance with the VOC ceiling. While Finland has been faced with a recent increase in its $\mathrm{NO}_{\mathrm{X}}$ emission, according to projecttions the country remains on track for the 2010 ceiling. Norway already complies with the ceilings for $\mathrm{SO}_{2}$ and $\mathrm{NH}_{3}$, but projections indicate that ceilings could be exceeded in 2010 unless additional measures are introduced.

3. Overall, increased activity in transport sectors seems to be the most significant contributory factor regarding difficulties in reaching the $\mathrm{NO}_{\mathrm{X}}$ ceilings. The most cost-effective abatement options available, at less than $€ 1 / \mathrm{kgNO}_{\mathrm{X}}$, appear to be in the offshore and shipping sectors. Requirements for ceilings stricter than those determined by the Gothenburg Protocol could be possible at less than $€ 1 / \mathrm{kg}$ for $\mathrm{SO}_{2}$, but would appear to require $€ 7 / \mathrm{kg}$ or more for $\mathrm{NO}_{\mathrm{X}}$. Estimates have not been identified for VOC and $\mathrm{NH}_{3}$.

4. The Gothenburg Protocol is flexible in that it is entirely up to protocol parties how they comply with the ceilings. A review of ex-post studies, relating in particular to economic incentives introduced at the national level that are supplementary to command-and-control measures contained in EU directives, indicates that the economic incentives have reinforced structural change towards lower and 
cleaner fuel use as well as intensified abatement efforts in the Nordic countries. Denmark, with an $\mathrm{SO}_{2}$ tax of just $€ 1.3 / \mathrm{kg} \mathrm{SO}$, has obtained the lowest $\mathrm{SO}_{2}$ emission rate per unit of GDP in the OECD, despite its coal-intensive energy sector. Finland shifted tax pressure from labour to a carbon-energy tax and obtained a $5 \%$ reduction in fuel use, especially for coal and heavy fuel oil. Sweden has introduced a successful differentiation of port dues for ships calling at harbours that vary according to emission intensity. Norway will recycle revenue from its $\mathrm{NO}_{\mathrm{X}}$ tax to allow energy-intensive industries to implement reduction measures.

5. The value and effectiveness of the Gothenburg Protocol, especially from a Nordic perspective, could be improved if the Russian Federation was involved as a signatory. Emissions in Russia are increasing again with revitalization of the economy, while the Gothenburg Protocol is based on ceilings for North-West Russia including St. Petersburg, Kaliningrad and Murmansk. $\mathrm{SO}_{2}$-emissions from just one 'hot-spot' near Murmansk, are equivalent to $\mathrm{SO}_{2}$-emissions from all sources in Finland and Norway. The benefits that were expected from these areas in return for efforts on the part of protocol parties have not fully materialized. An apparent paradox is that Russia under the former Soviet Union was an initiator of the Convention of LongRange Transport of Air Pollutants (CLRTAP).

6. Latest scientific findings suggest that current levels of exposure to fine particulate matter cause significant reductions in life expectancy. For this reason an amended protocol should balance ceilings for emissions of secondary aerosols with new ceilings for primary particles $\left(\mathrm{PM}_{2.5}\right)$ so as to maximize the overall benefit of the emissions reductions. Data collection and monitoring of natural and organic parts of the particle mass could also usefully be systematized and improved as part of the protocol. The RAINS-GAINS framework will be a useful decision-support tool for the purpose of revising or amending the protocol: however, it is recommended to explore better the significance of non-linearities in atmospheric chemistry and transport for the assumptions in the RAINS-GAINS framework, so as to check expected outcomes for signatories.

7. Health benefits according to results from the EU's Clean Air for Europe (CAFE) programme are believed to dominate monetary values of emissions reductions. Modelling indicates that benefits are in the range of $€ 7-15 / \mathrm{kg} \mathrm{NO}_{X}$ in the most populated parts of the Nordic area. Under a future amendment to the protocol and with an assessment based primarily on the value of health benefits, even higher benefits can be expected to arise in the more populated regions of Europe. Central European countries would appear to have considerably higher benefit-cost ratios than Nordic countries. While these circumstances will no doubt be helpful and beneficial for negotiations 
and subsequent implementation, the concerns about ecosystems (lakes and forests) which triggered the Nordic initiative in CLRTAP more than 20 years ago should not be neglected and methods to integrate the critical loads for ecosystems need to be better incorporated within the assessment framework.

8. Reductions in air pollution from conventional pollutants constitute ancillary benefits in the context of climate policy under which fossil fuel consumption needs to be reduced. Significant changes in energy and transport systems are to be expected in coming decades in order to contain climate change within a $2^{\circ} \mathrm{C}$ limit. While some alternative energy sources, such as solar, wind and wave power, are associated with limited amounts of air pollutants, other renewables, notably biofuels including waste incineration, will very likely result in higher emission intensities. Parallel negotiations under CLRTAP and the UNFCCC framework hence call for closer coordination. 



\section{Introduction}

The purpose of this report is to offer a Nordic perspective on how the 1999 Gothenburg Protocol on emissions of $\mathrm{NO}_{\mathrm{X}}, \mathrm{SO}_{\mathrm{X}}, \mathrm{NH}_{3}$, and VOC has been functioning; the measures that have been taken in the Nordic countries, the effect the measures have had, and how implementation of reductions agreed under the protocol might be attained. Specific attention is directed towards the question of whether measures taken to reach the goals are cost-effective. As such, the report provides input to the revision process currently underway under the terms of the protocol.

A 2004 study concluded that very few ex post evaluations of European air pollution measures that consider cost-effectiveness exist (Milieu 2004b: 2). However, some experience with this issue has been gained in the Nordic countries.

Chapter 2 contains a short introduction to the Convention on LongRange Transboundary Air Pollution (CLRTAP) and the Gothenburg Protocol. Furthermore, the revision processes of the National Emissions Ceilings Directive and the Gothenburg Protocol are briefly addressed.

Chapter 3 presents an overview of emission trends for each of the five Nordic countries, including Iceland which is not a signatory to the protocol. Trends, moreover, are projected with the purpose of providing a foundation for determining whether or not the Nordic countries will reach their respective goals as defined in the Gothenburg Protocol.

Chapter 4 offers a meta-evaluation of applied policy instruments. By means of a literature review, relevant evaluations of air pollution measures directed at $\mathrm{NO}_{\mathrm{X}}, \mathrm{SO}_{\mathrm{X}}, \mathrm{NH}_{3}$, and/or $\mathrm{VOC}$ emissions have been identified. In particular, focus is on economic instruments. Each evaluation is briefly described. Finally, progress in reaching the goals of the Gothenburg Protocol in a cost-effective manner is discussed ${ }^{1}$.

Chapter 5 discusses future developments. The chapter contains a short discussion of the debate on percentage limits versus fixed limits. This is followed by a discussion of whether it is possible to make the protocol more flexible; and there is a short discussion of the RAINS-GAINS model. Furthermore, potential inclusion of primary particles in a new protocol as well as the importance of a strong coupling between measures taken to reduce the emissions of traditional air pollutants and greenhouse gases are discussed. Finally, it is discussed how future Nordic air pollution measures might be designed with reference to cost-effectiveness.

\footnotetext{
${ }^{1}$ All amounts are converted to $€$. Exchange rates as of 15 May 2008.
} 



\section{Background}

The five Nordic countries - Denmark, Finland, Iceland, Norway, and Sweden - all signed the Geneva Convention on Long-range Transboundary Air Pollution (CLRTAP) in 1979. Since then, the convention has been extended by eight protocols specifying measures to be taken by the parties to cut emissions of air pollutants. The last protocol in the series is the 1999 Gothenburg Protocol to Abate Acidification, Eutrophication and Ground-level Ozone.

\subsection{The Convention on Long-range Transboundary Air Pollution}

The roots of the Convention on Long-range Transboundary Air Pollution (CLRTAP) can be traced back to the 1960s, where scientists were able to demonstrate a causal link between sulphur emissions in continental Europe and acidification of Scandinavian lakes. During the 1970s several scientific studies confirmed that air pollutants can travel thousands of kilometres before being deposited and causing damage, indicating that international cooperation to solve air pollution problems would prove beneficial (www.unece.org; see also Grover 2007).

In 1979, CLRTAP was adopted within the framework of the United Nations Economic Commission for Europe (UNECE). When the membership list was last updated (April 2008), 51 of UNECE's 56 members were party to the convention, thereby committing themselves to:

'by means of exchanges of information, consultation, research and monitoring develop without undue delay policies and strategies which shall serve as a means of combating the discharge of air pollutants, taking into account efforts already made at national and international levels' (UNECE 1979, art.3).

The convention is unique among international environmental agreements in its specifically science-driven process to achieve the goals (Ishii 2001).

Since adoption of the convention in 1979, eight subsequent protocols have entered into force. Not all of today's 56 members of UNECE have signed the protocols. In April 2008, the various protocols have been signed by between 22 and 42 parties (see Table 2.1). 
Table 2.1 Protocols to the Convention on Long-range Transboundary Air Pollution

\begin{tabular}{llcc}
\hline $\begin{array}{l}\text { Year } \\
\text { adopted }\end{array}$ & Protocol & $\begin{array}{c}\text { Entered } \\
\text { into force }\end{array}$ & $\begin{array}{c}\text { Number of parties to the } \\
\text { protocol (last update: } \\
\text { September 2007) }\end{array}$ \\
\hline 1984 & $\begin{array}{l}\text { The Geneva Protocol on Long-term Financing of } \\
\text { the Cooperative Programme for Monitoring and } \\
\text { Evaluation of the Long-range Transmission of Air } \\
\text { Pollutants in Europe (EMEP) }\end{array}$ & 1988 & 42 \\
1985 & $\begin{array}{l}\text { The Helsinki Protocol on the Reduction of Sul- } \\
\text { phur Emissions or their Transboundary Fluxes by } \\
\text { at least 30 per cent }\end{array}$ & 1987 & 23 \\
1988 & $\begin{array}{l}\text { The Sofia Protocol concerning the Control of } \\
\text { Emissions of Nitrogen Oxides or their Trans- } \\
\text { boundary Fluxes }\end{array}$ & 1991 & 22 \\
1991 & $\begin{array}{l}\text { The Geneva Protocol concerning the Control of } \\
\text { Emissions of Volatile Organic Compounds or } \\
\text { their Transboundary Fluxes } \\
\text { The Oslo Protocol on Further Reduction of } \\
\text { Sulphur Emissions } \\
\text { The Aarhus Protocol on Heavy Metals }\end{array}$ & 1997 & 29 \\
1998 & $\begin{array}{l}1998 \\
\text { The Aarhus Protocol on Persistent Organic } \\
\text { Pollutants (POPs) }\end{array}$ & 2003 & 29 \\
\hline $\begin{array}{l}\text { The Gothenburg Protocol to Abate Acidification, } \\
\text { Eutrophication and Ground-level Ozone }\end{array}$ & 2003 & 29 \\
\hline
\end{tabular}

Source: Table based on information at www.unece.org April 2008.

Denmark, Finland, Norway, and Sweden have signed and ratified the entire series of protocols. Iceland has signed (but not ratified) the 1998 Aarhus Protocol on Heavy Metals, and signed and ratified the 1998 Aarhus Protocol on Persistent Organic Pollutants (POPs) (www.unece.org). Iceland, however, has not signed/ratified the remaining protocols. Iceland considered becoming a party to the 1988 and 1991 protocols but decided against this. Nevertheless, Iceland has committed itself to reduce $\mathrm{NO}_{\mathrm{x}}$ emissions by $30 \%$ and VOC emissions by $50 \%$ during the period 1998 to 2005 according to the Nordic action plan (OECD 2001b: 110).

\subsection{The Gothenburg Protocol}

The Gothenburg Protocol is the most complex protocol under the convention. It is a multi-pollutant, multi-control approach which, in addition, has technically very detailed annexes (UNECE 2008). Agreement on the Gothenburg Protocol represented therefore a very important step on the road towards fulfilling the overall goal of the Convention on Long-range Transboundary Air Pollution. The protocol employs national emission targets and sets of emission limit values that should be reached by 2010 . The objective is to:

'... control and reduce emissions of sulphur, nitrogen oxides, ammonia and volatile organic compounds that are caused by anthropogenic activities and are likely to cause adverse effects on human health, natural ecosystems, materials and crops, due to acidification, eutrophication or ground-level ozone as a result of long-range 
transboundary atmospheric transport, and to ensure, as far as possible, that in the long term and in a stepwise approach, taking into account advances in scientific knowledge, atmospheric depositions or concentrations do not exceed [specified limits]' (UNECE 1999)

Furthermore, it is e.g. stated in the protocol, that the parties to the protocol are:

'[a]ware that nitrogen oxides, sulphur, volatile organic compounds and reduced nitrogen compounds have been associated with adverse effects on human health and the environment ... [and are] [a]ware that techniques and management practices are available to reduce emissions of these substances ... [and are] [c]onscious of the need for a cost-effective regional approach to combating air pollution that takes account of the variations in effects and abatement costs between countries ... [and are] [b]earing in mind that measures taken to reduce emissions of sulphur, nitrogen oxides, ammonia and volatile organic compounds should not constitute a means of arbitrary or unjustifiable discrimination or a disguised restriction on international competition and trade ... [and are] [n] oting furthermore that this Protocol is the first agreement under the Convention to deal specifically with reduced nitrogen compounds ... [and are] [b]earing in mind that reducing the emissions of these substances may provide additional benefits for the control of other pollutants, including in particular transboundary secondary particulate aerosols, which contribute to human health effects associated with exposure to airborne particulates ...' (UNECE 1999)

From the citation it is evident that there is an explicit focus on obtaining cost-effective solutions at a regional level. East and southeast of the Nordic countries, many European non-signatories/non-ratifiers of the protocol can be found, e.g.: the Russian Federation, Ukraine, Belarus, Poland and Estonia (see Table 2.2). While the former Soviet Union was one of the driving forces in establishing the UNECE framework for the original convention, unfortunately in the successor countries, notably Russia and Ukraine, interest in the issues has declined. 
Table 2.2 Status of ratification of the 1999 Gothenburg Protocol to Abate Acidification, Eutrophication and Ground-level Ozone as of 18 September 2007

\begin{tabular}{|c|c|c|}
\hline Party & Signature & Ratification* \\
\hline Armenia & 1.12.1999 & \\
\hline Austria & 1.12.1999 & \\
\hline Belgium & 4.02 .2000 & 18.09.2007 (R) \\
\hline Bulgaria & 1.12.1999 & 05.07.2005 (R) \\
\hline Canada & 1.12.1999 & \\
\hline Croatia & 1.12.1999 & \\
\hline Cyprus & & 11.04.2007 (Ac) \\
\hline Czech Republic & 1.12.1999 & 12.08.2004 (R) \\
\hline Denmark & 1.12.1999 & 11.06.2002 (Ap)(6) \\
\hline Finland & 1.12.1999 & 23.12 .2003 \\
\hline France & 1.12.1999 & 10.04.2007 (Ap) \\
\hline Germany & 1.12.1999 & 27.10.2004 (R) \\
\hline Greece & 1.03 .2000 & \\
\hline Hungary & 1.12.1999 & 17.11.2006 (Ap) \\
\hline Ireland & 1.12.1999 & \\
\hline Italy & 1.12.1999 & \\
\hline Latvia & 1.12.1999 & 25.05.2004 (At) \\
\hline Liechtenstein & 1.12.1999 & \\
\hline Lithuania & & $02.04 .2004(\mathrm{Ac})$ \\
\hline Luxemburg & 1.12.1999 & 07.08.2001 (R) \\
\hline Netherlands & 1.12.1999 & 05.02.2004 (At) \\
\hline Norway & 1.12.1999 & $30.01 .2002(\mathrm{R})$ \\
\hline Poland & 30.05 .2000 & \\
\hline Portugal & 1.12.1999 & 16.02.2005 (Ap) \\
\hline Republic of Moldova & 23.05 .2000 & \\
\hline Romania & 1.12.1999 & $05.09 .2003(R)$ \\
\hline Slovakia & 1.12.1999 & $28.04 .2005(R)$ \\
\hline Slovenia & 1.12.1999 & 04.05.2004 (R) \\
\hline Spain & 1.12.1999 & $28.01 .2005(\mathrm{R})$ \\
\hline Sweden & 1.12.1999 & $28.03 .2002(R)$ \\
\hline Switzerland & 1.12.1999 & $14.09 .2005(\mathrm{R})$ \\
\hline United Kingdom & 1.12.1999 & $08.12 .2005(R)$ \\
\hline United States of America & 1.12.1999 & 22.11 .04 (At) \\
\hline European Community & & $23.06 .2003(\mathrm{Ac})$ \\
\hline
\end{tabular}

* $R=$ Ratification, $A c=A c c e s s i o n, A p=A p p r o v a l, A t=A c c e p t a n c e, S c=S u c c e s s i o n$

Source: www.unece.org

To date, the 1999 Gothenburg Protocol to Abate Acidification, Eutrophication and Ground-level Ozone is the last protocol under the convention. The Gothenburg Protocol's emission ceilings for $\mathrm{SO}_{2}, \mathrm{NO}_{2}, \mathrm{NH}_{3}$ and VOC for the four Nordic signatories are listed in Table 2.3 to 2.6. 
Table 2.3 Emission ceilings for sulphur (1000 tonnes $\mathrm{SO}_{2}$ per year)

\begin{tabular}{lrrr}
\hline & \multicolumn{2}{c}{ Emission levels } & Ceilings \\
& 1980 & 1990 & 2010 \\
\hline Denmark & 450 & 182 & 55 \\
Finland & 584 & 260 & 116 \\
Norway & 137 & 53 & 22 \\
Sweden & 491 & 119 & 67 \\
\hline
\end{tabular}

Source: UNECE 1999

Table 2.4 Emission ceilings for nitrogen oxides (1000 tonnes of $\mathrm{NO}_{2}$ per year)

\begin{tabular}{lrr} 
& Emission levels & Ceilings \\
& 1990 & $\mathbf{2 0 1 0}$ \\
\hline Denmark & 282 & 127 \\
Finland & 300 & 170 \\
Norway & 218 & 156 \\
Sweden & 338 & 148 \\
\hline
\end{tabular}

Source: UNECE 1999

Table 2.5 Emission ceilings for ammonia (1000 tonnes of $\mathrm{NH}_{3}$ per year)

\begin{tabular}{lrr}
\hline & Emission levels & Ceilings \\
& $\mathbf{1 9 9 0}$ & $\mathbf{2 0 1 0}$ \\
\hline Denmark & 122 & 69 \\
Finland & 35 & 31 \\
Norway & 23 & 23 \\
Sweden & 61 & 57 \\
\hline
\end{tabular}

Source: UNECE 1999

Table 2.6 Emission ceilings for VOC (1000 tonnes of VOC per year)

\begin{tabular}{lrr}
\hline & Emission levels & Ceilings \\
& $\mathbf{1 9 9 0}$ & $\mathbf{2 0 1 0}$ \\
\hline Denmark & 178 & 85 \\
Finland & 209 & 130 \\
Norway & 310 & 195 \\
Sweden & 526 & 241 \\
\hline
\end{tabular}

Source: UNECE 1999

According to the Gothenburg Protocol, a revision process should start no later than one year after sufficent ratification for the protocol to enter into force. The Gothenburg Protocol took effect from 17 May 2005 and the revision process was initiated in 2006 (CIAM (2007), for example, represents a contribution in this regard). Whereas the Gothenburg Protocol set emission ceilings for 2010, it is expected that new ceilings for the period to 2020 are likely to be agreed upon. Furthermore, it is expected that ceilings for particulate matter will be incorporated in the protocol.

According to CIAM (2007) a considerable potential for further costeffective emission control measures exists for the four pollutants; in particular, when the positive side-effects on greenhouse gas emissions are also taken into consideration. New emerging technologies, non-technical 
and local measures, integrated nitrogen management and reduction of ship emissions offer cost-effective options to reduce emissions further (CIAM 2007: 51).

To enable a cost-effective outcome, a revised protocol should, according to CIAM (2007: 51), take into account linkages with primary PM emissions, hemispheric transport of air pollution and ship emissions, as well as the potential synergies and trade-offs in relation to climate change policy and management of the nitrogen cycle.

The Task Force on Integrated Assessment Modelling is planning to continue to assess progress in European-wide integrated assessment modelling, especially the RAINS-GAINS model. Special attention is directed towards the inclusion of costs and effects of greenhouse gas abatement options, integrated nitrogen approaches and abatement measures for ship emissions (CIAM 2007: 54).

At its twenty-fifth session in December 2007, the Executive Body for the Convention on Long-Range Transboundary Air Pollution mandated the Working Group on Strategies and Review to start negotiations on further obligations to reduce emissions. The aim is to present the outcome of the negotiations at the twenty-seventh meeting in December 2009 (UNECE 2008).

Review of the Gothenburg Protocol highlighted a number of issues which will be addressed during the revision process in 2008. The Executive Body agrees with the review that there should be focus on particulate matter (PM), the hemispheric transport of air pollution, the potential synergies and trade-offs with climate change, the nitrogen cycle, and shipping emissions (UNECE 2008: 2). Additionally, needless to say, there is an interest in making non-signatories commit to binding emission reduction measures.

Regarding emission ceilings, it is the Executive Body's opinion that new targets (e.g. for 2020) should be considered. Furthermore, the Executive Body recommended that the revision process 'should take into account modelled optimized scenarios covering the whole geographic scope of EMEP without excluding the development of differentiated approaches for different UNECE subregions' (UNECE 2008: 3). Complete sourcereceptor matrices for the entire geographic scope of EMEP are expected in August 2008. CIAM will present technical options for specific measures in the regions of Eastern Europe, Caucasus, and Central Asia. A considerable potential for emission reduction in these regions is expected. Ceilings for the current legislation scenario will be calculated and presented in September 2008. After this, there will be further scenario calculation and a scenario for negotiation will be selected. According to the plan, new emission ceilings should be agreed upon in September 2009 (UNECE 2008).

A new protocol might loosen requirements in the technical annexes, because there are indications that these annexes present a barrier for some 
countries' ratification of the protocol. Furthermore, it is almost certain that the new protocol will allow for more flexibility - e.g. with respect to timescales for implementation of obligations (UNECE 2008: 5).

\subsection{The National Emission Ceilings Directive}

Parallel to commitments under the Gothenburg Protocol, Sweden, Finland and Denmark are bound by the EU directive on National Emission Ceilings (NEC) (European Parliament and the Council 2001). The directive sets upper limits regarding air pollution for the member states emissions in 2010 for the same four pollutants as the Gothenburg Protocol $\left(\mathrm{SO}_{2}, \mathrm{NO}_{\mathrm{X}}, \mathrm{NH}_{3}\right.$ and VOC $)$ - pollutants causing acidification, eutrophication, and ground-level ozone.

The EU National Emission Ceilings Directive contains the same ceilings as the Gothenburg Protocol with one exception; the Finnish ceiling for $\mathrm{SO}_{2}$ is 110,000 tonnes compared to 116,000 tonnes in the Gothenburg Protocol (The European Parliament and the Council 2001: 12),

Implementation of the EU Thematic Strategy on Air Pollution involves that a new NEC Directive for the period 2010 to 2020 will be agreed upon. In addition to the four existing pollutants, particulate matter (PM) will be included in the new directive (Bach et al. 2006: 31). This was emphasised when the European Parliament on 11 December 2007, following an agreement with the Council, voted in favour of air quality legislation that sets limits on fine particle pollution $\left(\mathrm{PM}_{2.5}\right)$, paving the way for an EU agreement among environment ministers in April 2008. The ceiling is expected to represent a $20 \%$ cut during the period 2010 to 2020. Furthermore, there will be a limit value of 25 microgram per $\mathrm{m}^{3}$ for 2015, and an indicative limit value of 20 microgram per $\mathrm{m}^{3}$ target for 2020. Similar $\mathrm{PM}_{2.5}$ targets were passed in the US more than ten years ago. The limit value for $\mathrm{PM}_{10}$ (on average 40 micrograms per $\mathrm{m}^{3}$ per year) will not be updated (EurActiv.com 12.12.2007).

The three EU members among the Nordic countries are also subject to other EU regulation regarding emissions of the four pollutants. For instance, directives on $\mathrm{NO}_{\mathrm{X}}$ emissions, vehicles, etc. (see Environmental Protection Agency 2006a: 24ff). Moreover, part of the EU's attention is currently focused on air pollution emissions from shipping and airlines (EurActiv.com 20.12.2007; 13.02.2008).

In May 2008, an EEA report indicated that there is potential for further cuts in $\mathrm{SO}_{2}$, and $\mathrm{NO}_{\mathrm{X}}$ in large European combustion plants through application of best available techniques (BAT). According to the report, based on the 2004 emission level, it is possible to reduce $\mathrm{SO}_{2}$ by up to 97 $\%$ and $\mathrm{NO}_{\mathrm{X}}$ by up to $87 \%$ (ENDS 2008a). Additionally, the European Parliament has stressed the importance of introducing further marketbased instruments in European environmental policy, complemented by 
efficiency standards and emission targets (ENDS 2008b). A 2008 Eurobarometer survey showed that nearly two-thirds of Europeans believe that environmental protection must be given priority over competitiveness (ENDS 2008c). While air pollutants such as $\mathrm{SO}_{2}$, VOC and $\mathrm{NO}_{\mathrm{X}}$ are declining, emission levels of other air pollutants are rising. Large particulate matter $\left(\mathrm{PM}_{10}\right)$, nitrogen dioxide $\left(\mathrm{NO}_{2}\right)$, and ozone concentrations all exceeded legal limits in a 'considerably' higher proportion of measured zones in 2005 than in 2001 (ENDS 2008d). 


\section{Emission trends and projections}

In general, the goals for $\mathrm{NO}_{\mathrm{X}}$ reduction are proving the most problematic for parties to the Gothenburg Protocol. For instance, eleven EU member states predict that they will not reach the $\mathrm{NO}_{\mathrm{X}}$ ceilings in 2010 , while emission reductions for the three other pollutants seem to be more on track (ENDS 2007). Likewise, the $\mathrm{NO}_{\mathrm{x}}$ goal seems to represent the toughest target for the Nordic countries.

This section presents emission trends, projections and emission ceilings for the Nordic countries that have ratified the Gothenburg Protocol (UNECE 1999): Denmark, Finland, Norway, and Sweden. For Iceland, who has ratified the Convention on Long-range Transboundary Air Pollution (UNECE 1979) but not the Gothenburg Protocol, emission trends only are presented.

\subsection{Denmark}

\subsubsection{Emission trends}

Table 3.1 presents the emission of $\mathrm{SO}_{2}, \mathrm{NO}_{\mathrm{X}}, \mathrm{NMVOC}$, and $\mathrm{NH}_{3}$ in Denmark 1990-2006 (Denmark 2007).

Table 3.1 Emission of $\mathrm{SO}_{2}, \mathrm{NO}_{x}, \mathrm{NMVOC}$, and $\mathrm{NH}_{3}$ in Denmark 1990-2006 (ktonne) (Denmark 2007)

\begin{tabular}{lrrrrrrrrrr}
\hline & 1990 & 1991 & 1992 & 1993 & 1994 & 1995 & 1996 & 1997 & 1998 & 1999 \\
\hline $\mathrm{SO}_{2}$ & 178 & 235 & 183 & 148 & 147 & 137 & 172 & 99.5 & 76.3 & 55.1 \\
$\mathrm{NO}_{x}$ & 274 & 323 & 280 & 281 & 283 & 266 & 304 & 259 & 236 & 221 \\
$\mathrm{NMVOC}^{2}$ & 170 & 171 & 168 & 166 & 162 & 159 & 156 & 145 & 136 & 131 \\
$\mathrm{NH}_{3}$ & 108 & 106 & 104 & 104 & 99.1 & 93.9 & 91.3 & 90.9 & 92.9 & 90.6 \\
\hline & 2000 & 2001 & 2002 & 2003 & 2004 & 2005 & 2006 & & & \\
\hline $\mathrm{SO}_{2}$ & 28.5 & 26.6 & 24.9 & 31.6 & 24.9 & 21.8 & 25.0 & & & \\
$\mathrm{NO}_{x}$ & 205 & 203 & 199 & 208 & 193 & 184 & 185 & & & \\
$\mathrm{NMVOC}$ & 127 & 120 & 118 & 113 & 114 & 114 & 108 & & & \\
$\mathrm{NH}_{3}$ & 89.5 & 88.7 & 86.3 & 82.0 & 83.8 & 78.5 & 75.2 & & & \\
\hline
\end{tabular}

The emissions of $\mathrm{SO}_{2}, \mathrm{NO}_{\mathrm{X}}, \mathrm{NMVOC}$ and $\mathrm{NH}_{3}$ in different sectors as well as trends are presented in Figures 3.1-3.4. 

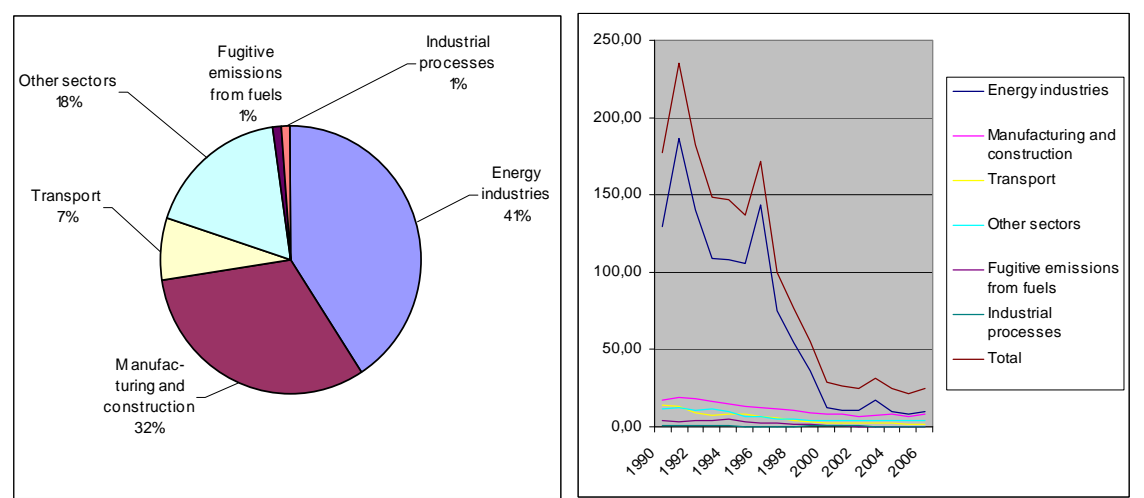

Figure 3.1. $\mathrm{SO}_{2}$ distribution (2006) and trends (ktonne) for Denmark (Denmark 2007)

Energy industries are the most significant source of $\mathrm{SO}_{2}$ emission in Denmark; see Figure 3.1. From 1990 the total emission of $\mathrm{SO}_{2}$ has been reduced from 178 to 25 ktonnes, and at the same time the share from Energy industries has been reduced from $73 \%$ to $41 \%$, i.e. a reduction in the specific emission from Energy industries of $93 \%$. This reduction can be explained by reduction of the sulphur content in fuel and installation of flue gas cleaning equipment at power plants and waste incineration plants.
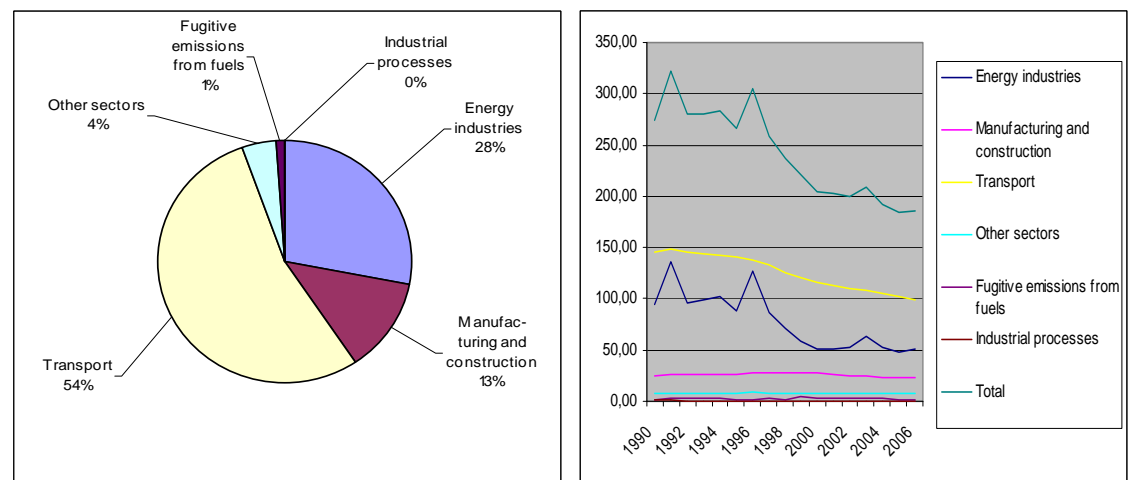

Figure 3.2. $N O_{X}$ distribution (2006) and trends (ktonne) for Denmark (Denmark 2007)

Transport and Energy industries are the most significant sources of $\mathrm{NO}_{\mathrm{X}}$ emission in Denmark; see Figure 3.2. The total emission has been reduced from 274 to 185 ktonne. The emission of $\mathrm{NO}_{\mathrm{X}}$ from Transport and Energy industries represents $53 \%$ and $35 \%$ of the total emission, respectively, in 1990. In 2006, the respective shares were $54 \%$ and $28 \%$. 

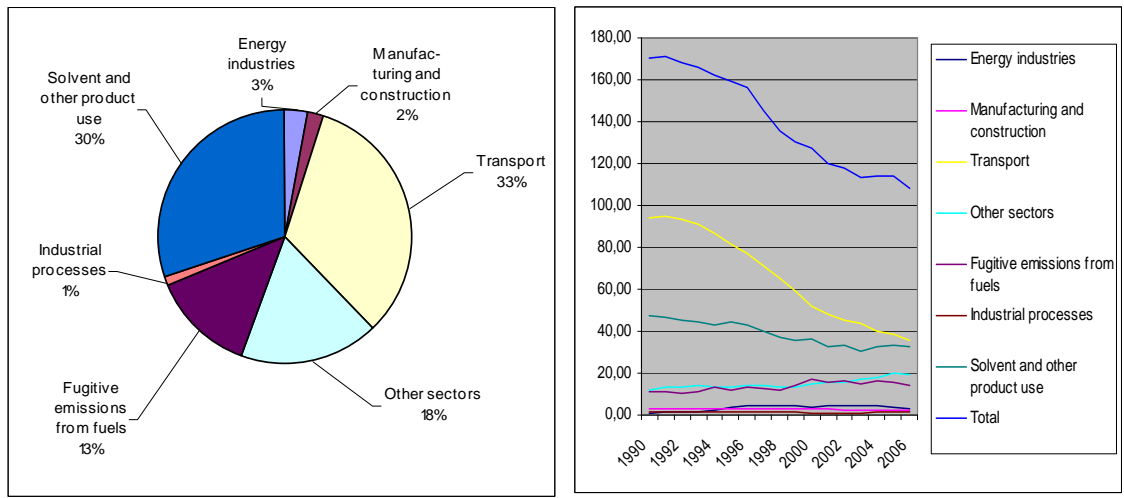

Figure 3.3. NMVOC distribution (2006) and trends (ktonne) for Denmark (Denmark 2007)

The emission of NMVOC has been reduced from 170 to 108 ktonnes; see Figure 3.3. Transport and Solvent and other product use are the most significant sources. In 1990 Transport and Solvent and other product use contributed with $55 \%$ and $28 \%$ of the total emission, respectively. In 2006 the respective shares were $33 \%$ and $30 \%$.
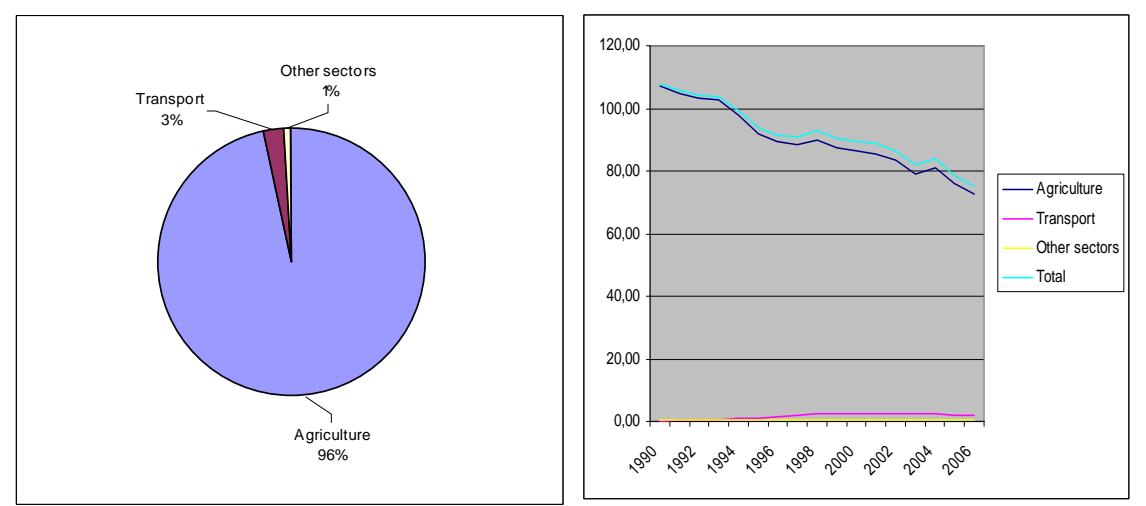

Figure 3.4. $\mathrm{NH}_{3}$ distribution (2006) and trends (ktonne) for Denmark (Denmark 2007)

Agriculture represents the most significant source of the emission of $\mathrm{NH}_{3}$, accounting for more than $97 \%$ of the total emission. The total emission has been reduced from 108 to 75 ktonnes; see Figure 3.4.

\subsubsection{Projections and emission ceilings}

Figure 3.5 presents the latest reported 'current legislation projections' of 06.12.2007. The national emission ceilings according to the Gothenburg Protocol (UNECE, 1999) for $\mathrm{SO}_{2}, \mathrm{NO}_{\mathrm{X}}, \mathrm{NMVOC}$ and $\mathrm{NH}_{3}$ are 55, 127, 85 and 69 ktonne, respectively. According to the latest projections Denmark will not be able to meet the ceilings for $\mathrm{NO}_{\mathrm{X}}$ and NMVOC unless new measures are implemented. 
TABLE IV 2A: Five-yearly, Minimum reporting of projected national total emissions of main pollutants Version 2002-1

\begin{tabular}{|c|c|c|c|c|c|c|c|}
\hline $\begin{array}{l}\text { COUNTRY: } \\
\text { DATE: } \\
\text { YEAR: }\end{array}$ & $\begin{array}{l}\text { DK } \\
06.12 .2007 \\
2010-2020\end{array}$ & \multicolumn{6}{|c|}{$\begin{array}{l}\text { (as ISO2 code) } \\
\text { (as DD.MM.YYYY) } \\
\text { (as YYYY, year of Emmissions) }\end{array}$} \\
\hline & UNIT & \multicolumn{3}{|c|}{ Current legislation projections ${ }^{\text {a) }}$} & \multicolumn{3}{|c|}{ Current reduction plans } \\
\hline Pollutant: & & 2010 & 2015 & 2020 & 2010 & 2015 & 2020 \\
\hline Sulphur oxides $\left(\mathrm{SO}_{\mathrm{x}}\right.$ as $\left.\mathrm{SO}_{2}\right)$ & Gg & 20 & 21 & 21 & $\mathrm{NE}$ & $\mathrm{NE}$ & NE \\
\hline Nitrogen oxides $\left(\mathrm{NO}_{\mathrm{x}}\right.$ as $\left.\mathrm{NO}_{2}\right)$ & Gg & 136 & 126 & 115 & $\mathrm{NE}$ & $\mathrm{NE}$ & NE \\
\hline $\begin{array}{l}\text { Non-methane volatile organic } \\
\text { compounds (NMVOC) }\end{array}$ & $\mathrm{Gg}$ & 88 & 80 & 76 & $\mathrm{NE}$ & $\mathrm{NE}$ & $\mathrm{NE}$ \\
\hline Ammonia $\left(\mathrm{NH}_{3}\right)$ & Gg & 65 & 58 & 55 & $\mathrm{NE}$ & $\mathrm{NE}$ & $\mathrm{NE}$ \\
\hline
\end{tabular}

${ }^{\text {a) }}$ Current legislation projections should be based on the activity projections as reported in tables IV 2B, IV 2C, IV 2D, and IV 2E in annex IV. Note:

For the definition of 'current legislation projections' and 'current reduction plans' please refer to paragraph 24 of the guidelines (chap. V). Figure 3.5. Report to UNECE: TABLE IV 2A: Five-yearly, Minimum reporting of projected national total emissions of main pollutants (Denmark 2007)

NE: not estimated

\subsection{Finland}

\subsubsection{Emission trends}

Table 3.2 presents the emission of $\mathrm{SO}_{2}, \mathrm{NO}_{\mathrm{X}}, \mathrm{NMVOC}$ and $\mathrm{NH}_{3}$ in Finland 1990-2006 (Finland 2006, 2007a, 2007b).

Table 3.2. Emission of $\mathrm{SO}_{2}, \mathrm{NO}_{x}, \mathrm{NMVOC}$, and $\mathrm{NH}_{3}$ in Finland 1990-2006 (ktonne) (Finland 2006, 2007a, 2007b)

\begin{tabular}{lrrrrrrrrrr}
\hline & 1990 & 1991 & 1992 & 1993 & 1994 & 1995 & 1996 & 1997 & 1998 & 1999 \\
\hline $\mathrm{SO}_{2}$ & 249 & 202 & 158 & 138 & 123 & 105 & 110 & 101 & 93.4 & 91.3 \\
$\mathrm{NO}_{x}$ & 294 & 277 & 266 & 267 & 267 & 245 & 248 & 239 & 224 & 220 \\
$\mathrm{NMVOC}$ & 229 & 217 & 210 & 202 & 197 & 192 & 185 & 180 & 176 & 171 \\
$\mathrm{NH}_{3}$ & $\mathrm{ni}$ & $\mathrm{ni}$ & $\mathrm{ni}$ & $\mathrm{ni}$ & $\mathrm{ni}$ & $\mathrm{ni}$ & $\mathrm{ni}$ & $\mathrm{ni}$ & $\mathrm{ni}$ & $\mathrm{ni}$ \\
\hline & 2000 & 2001 & 2002 & 2003 & $\mathbf{2 0 0 4}$ & $\mathbf{2 0 0 5}$ & $\mathbf{2 0 0 6}$ & & & \\
\hline $\mathrm{SO}_{2}$ & 80.8 & 89.7 & 90.5 & 101 & 83.5 & 69.2 & 84.1 & & & \\
$\mathrm{NO}_{x}$ & 210 & 210 & 209 & 217 & 205 & 177 & 193 & & & \\
$\mathrm{NMVOC}$ & 165 & 162 & 156 & 151 & 140 & 131 & 132 & & & \\
$\mathrm{NH}_{3}$ & ni & ni & ni & ni & 33.3 & 36.2 & 36.2 & & & \\
\hline
\end{tabular}

ni: no information

The emissions of $\mathrm{SO}_{2}, \mathrm{NO}_{\mathrm{x}}, \mathrm{NMVOC}$ and $\mathrm{NH}_{3}$ in different sectors as well as trends are presented in Figure 3.6-3.9. 

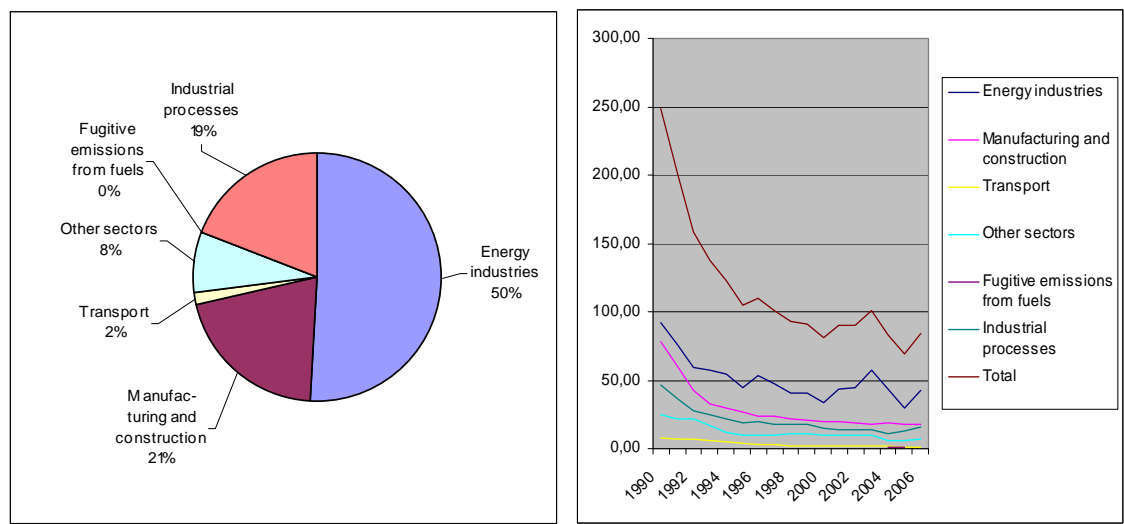

Figure 3.6. $\mathrm{SO}_{2}$ distribution (2006) and trends (ktonne) for Finland (Finland 2006, 2007a, 2007b)

Energy industries are the most significant source of $\mathrm{SO}_{2}$ emission in 2006 in Finland and contribute with $50 \%$ of the total emission; see Figure 3.6. From 1990 the total emission of $\mathrm{SO}_{2}$ has been reduced from 249 to 84.1 ktonne, with the most significant reduction having taken place in Energy industries. In 1990 Energy industries and Manufacturing and construction were responsible for $37 \%$ and $31 \%$ of the total emission, respectively, whereas Industrial processes accounted for $19 \%$. In 2006 the distribution changed and the shares for Manufacturing and construction and Industrial processes become $21 \%$ and $19 \%$, respectively. The reduction of the $\mathrm{SO}_{2}$ emission in Energy industries can be explained by the reduction in the sulphur content in fuel and installation of flue gas cleaning equipment, whereas the reduction in the emission in Manufacturing and construction and Industrial processes may be explained by reduced sulphur content in fuel.
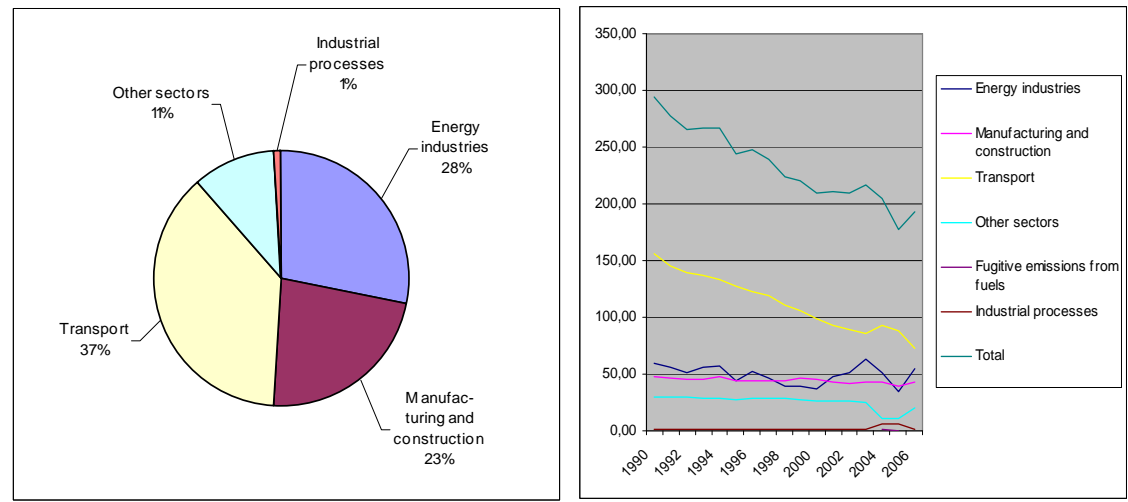

Figure 3.7. $\mathrm{NO}_{X}$ distribution (2006) and trends (ktonne) for Finland (Finland 2006, 2007a, 2007b)

Transport is the most significant source of the emission of $\mathrm{NO}_{\mathrm{X}}$; see Figure 3.7. In 1990 the emission of $\mathrm{NO}_{\mathrm{X}}$ from Transport represented $53 \%$ of the total emission and in 2006 the share reduces to $38 \%$. The emission of $\mathrm{NO}_{\mathrm{X}}$ from Energy industries and Manufacturing and construction repre- 
sents $28 \%$ and $23 \%$ of the total emission in 2006 , respectively. The total emission of $\mathrm{NO}_{\mathrm{X}}$ has been reduced from 294 ktonne in 1990 to 193 ktonne in 2006.
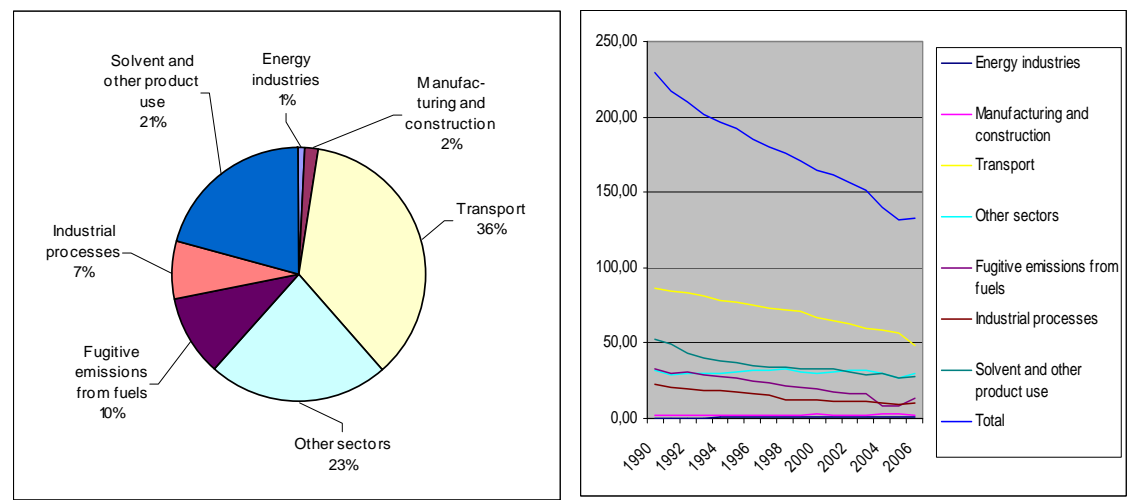

Figure 3.8. NMVOC distribution (2006) and trends (ktonne) for Finland (Finland 2006, 2007a, 2007b)

The emission of NMVOC has been reduced from 229 to 132 ktonne; see Figure 3.8. Transport is the most significant sector and is responsible for $36-38 \%$ of the total emission in 1990 and 2006, respectively. Other sectors and Solvent and other product use account for $23 \%$ and $21 \%$, respectively.
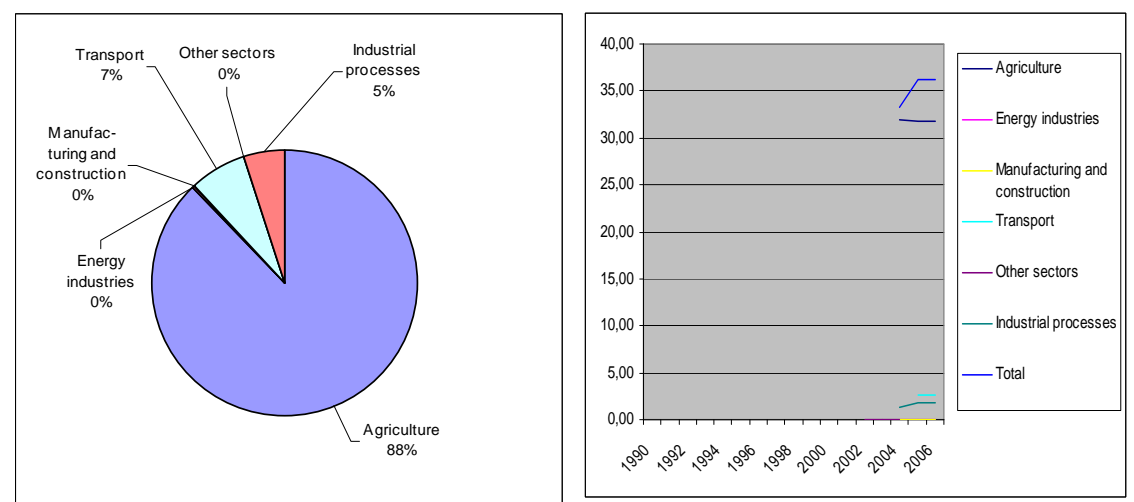

Figure 3.9. $\mathrm{NH}_{3}$ distribution (2006) and trends (ktonne) for Finland (Finland 2006, 2007a, 2007b)

Agriculture is the main source of the emission of $\mathrm{NH}_{3}$ and accounts for $88 \%$ of the total emission in 2006, see Figure 3.9. The emission from Transport is only estimated for 2005 and 2006, and represents $7 \%$ of the total emission for these years.

\subsubsection{Projections and emission ceilings}

Figure 3.10 presents the latest reported 'current legislation projections' of 15.02.2007. The national emission ceilings according to the Gothenburg Protocol (UNECE, 1999) for $\mathrm{SO}_{2}, \mathrm{NO}_{\mathrm{X}}, \mathrm{NMVOC}$ and $\mathrm{NH}_{3}$ are 116, 170, 
130 and 31 ktonne, respectively. According to the latest projections (Finland 2007b) Finland will be able to meet the limit values for all four substances.

\begin{tabular}{|c|c|c|c|c|c|c|c|}
\hline $\begin{array}{l}\text { COUNTRY: } \\
\text { DATE: } \\
\text { YEAR: }\end{array}$ & $\begin{array}{l}\mathrm{FI} \\
\begin{array}{l}15-02-2007 \\
2010 \& 2020\end{array}\end{array}$ & $\begin{array}{l}\text { (as ISO2 code } \\
\text { (as DD.MM.YY } \\
\text { (as YYYY, yea }\end{array}$ & Emmissior & & & & \\
\hline & $\overline{\text { UNIT }}$ & Current 1 & lation proje & ions $^{\text {a) }}$ & & reducti & \\
\hline Pollutant: & & 2010 & 2015 & 2020 & 2010 & 2015 & 2020 \\
\hline Sulphur oxides $\left(\mathrm{SO}_{\mathrm{x}}\right.$ as $\left.\mathrm{SO}_{2}\right)$ & Gg & 98 & $\mathrm{NE}$ & 97 & & & \\
\hline Nitrogen oxides $\left(\mathrm{NO}_{\mathrm{x}}\right.$ as $\left.\mathrm{NO}_{2}\right)$ & $\mathrm{Gg}$ & 151 & $\mathrm{NE}$ & 151 & & & \\
\hline $\begin{array}{l}\text { Non-methane volatile organic } \\
\text { compounds (NMVOC) }\end{array}$ & $\mathrm{Gg}$ & 130 & $\mathrm{NE}$ & $\mathrm{NE}$ & & & \\
\hline Ammonia $\left(\mathrm{NH}_{3}\right)$ & $\mathrm{Gg}$ & 31 & $\mathrm{NE}$ & $\mathrm{NE}$ & & & \\
\hline
\end{tabular}

${ }^{\text {a) }}$ Current legislation projections should be based on the activity projections as reported in tables IV 2B, IV 2C, IV 2D, and IV 2E in annex IV.

Note:
For the definition of 'current legislation projections' and 'current reduction plans' please refer to paragraph 24 of the guidelines (chap. V).

Figure 3.10. Report to UNECE: TABLE IV 2A: Five-yearly, Minimum reporting of projected national total emissions of main pollutants (Finland 2007b)

NE: Not estimated.

\subsection{Iceland}

\subsubsection{Emission trends}

Table 3.3 presents the emission of $\mathrm{SO}_{2}, \mathrm{NO}_{\mathrm{X}}$, and $\mathrm{NMVOC}$ in Iceland 1990-2004 (Iceland 2006).

Table 3.3 Emission of $\mathrm{SO}_{2}, \mathrm{NO}_{x}, \mathrm{NMVOC}$ and $\mathrm{NH}_{3}$ in Iceland 1990-2006 (ktonne) (Iceland 2006)

\begin{tabular}{lrrrrrrrrrr}
\hline & 1990 & 1991 & 1992 & 1993 & 1994 & 1995 & 1996 & 1997 & 1998 & 1999 \\
\hline $\mathrm{SO}_{2}$ & 7.25 & 6.42 & 7.35 & 7.82 & 7.32 & 7.42 & 7.65 & 7.97 & 7.58 & 7.90 \\
$\mathrm{NO}_{\times}$ & 27.4 & 27.7 & 29.3 & 30.5 & 30.2 & 29.6 & 30.9 & 30.2 & 29.5 & 28.5 \\
$\mathrm{NMVOC}$ & 12.7 & 14.1 & 13.9 & 13.4 & 14.0 & 11.9 & 11.9 & 9.77 & 9.90 & 7.81 \\
$\mathrm{NH}_{3}$ & ni & ni & ni & ni & ni & ni & ni & ni & ni & ni \\
\hline & 2000 & 2001 & 2002 & 2003 & 2004 & 2005 & 2006 & & & \\
\hline $\mathrm{SO}_{2}$ & 7.81 & 8.39 & 8.74 & 8.04 & 7.55 & ni & ni & & & \\
$\mathrm{NO}_{x}$ & 27.6 & 25.9 & 27.5 & 26.7 & 28.4 & ni & ni & & & \\
$\mathrm{NMVOC}^{2}$ & 8.23 & 8.93 & 7.80 & 7.10 & 7.43 & ni & ni & & & \\
$\mathrm{NH}_{3}$ & ni & ni & ni & ni & ni & ni & ni & & & \\
\hline
\end{tabular}

ni: no information.

The emissions of $\mathrm{SO}_{2}, \mathrm{NO}_{\mathrm{X}}$ and NMVOC in different sectors as well as trends are presented in Figure 3.11-3.13. 

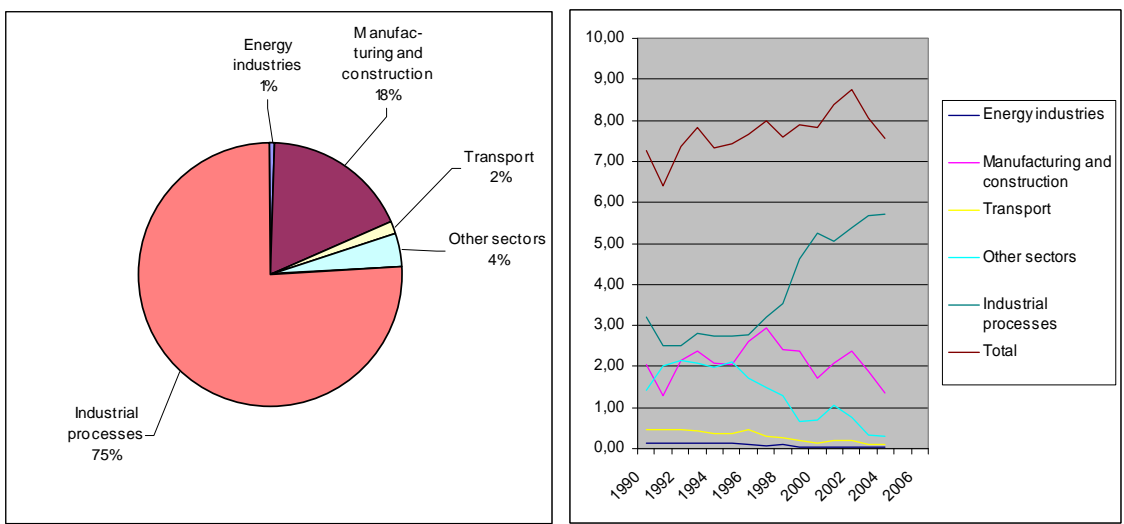

Figure 3.11. $\mathrm{SO}_{2}$ distribution (2004) and trends (ktonne) for Iceland (Iceland 2006)

The emission of $\mathrm{SO}_{2}$ shows a slight increase during the years 1990 to 2004; see Figure 3.11. The contribution from Industrial processes increases from $44 \%$ of the total emission in 1990 to $75 \%$ in 2004 . The second most important source in 2004 is Manufacturing and construction, which accounts for $18 \%$ of the total emission.
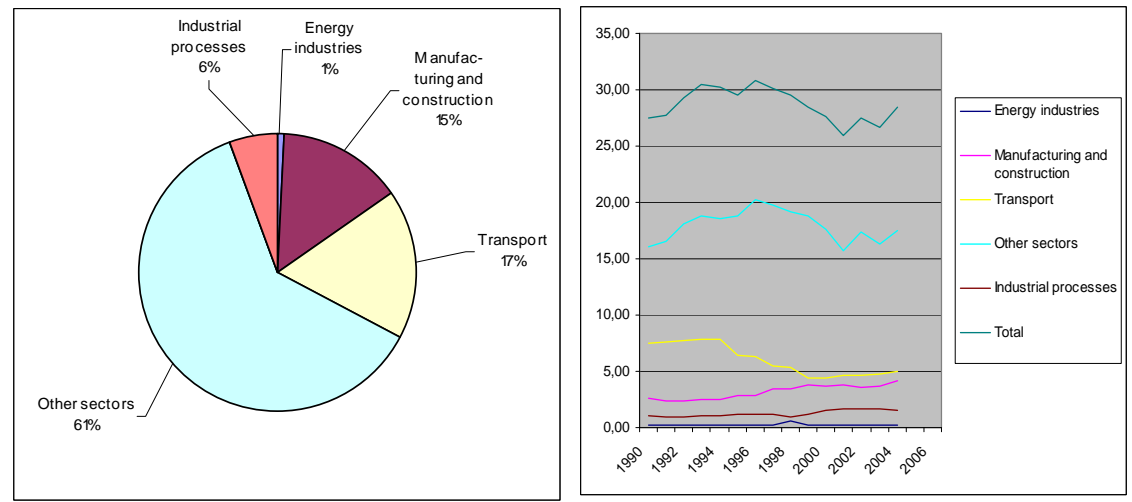

Figure $3.12 \mathrm{NO}_{X}$ distribution (2004) and trends (ktonne) for Iceland (Iceland 2006)

The emission of $\mathrm{NO}_{\mathrm{X}}$ has remained almost constant from 1990 to 2004 at a level of 25.9 to 30.9 ktonne; see Figure 3.12. Emissions from Other sectors - which include Agriculture/Forestry/Fisheries as the main sources - constitute $59 \%$ to $62 \%$ of the total emission of $\mathrm{NO}_{\mathrm{X}}$. Transport and Manufacturing and construction are the second most important sectors, accounting for $17 \%$ and $15 \%$ of the total emission. 

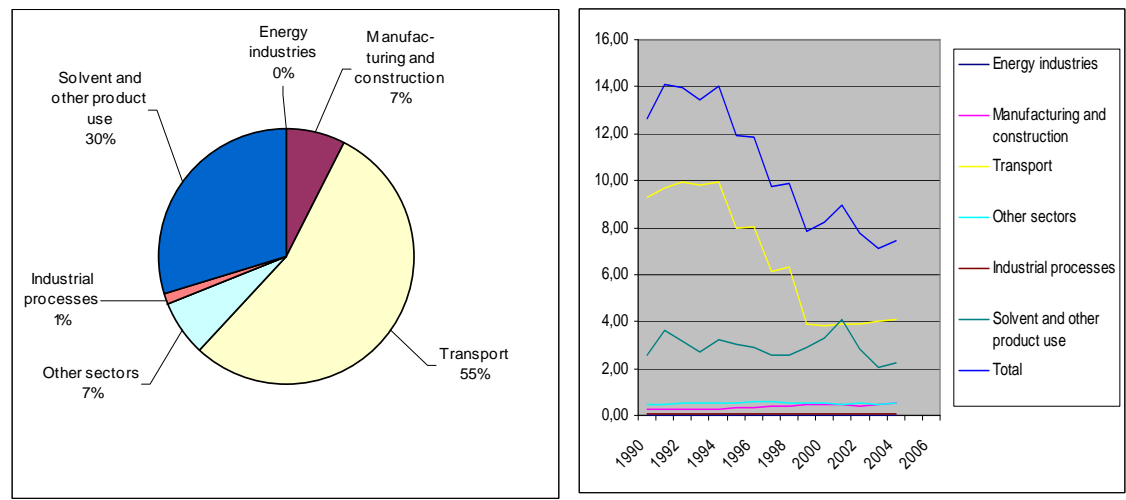

Figure 3.13. NMVOC distribution (2004) and trends (ktonne) for Iceland (Iceland 2006)

The emission of NMVOC has decreased from 12.7 to 7.43 ktonnes; see Figure 3.13 Transport is the most important sector regarding emission of NMVOC and the sector contirbutes with $73 \%$ of the total emission in 1990, falling to $55 \%$ in 2004 . Emissions from Solvent and other product use constitute from $20 \%$ to $30 \%$ of the total emission of NMVOC.

\subsubsection{Projections and emission ceilings}

Iceland is not a party to the Gothenburg protocol, but has committed itself to reduce $\mathrm{NO}_{\mathrm{X}}$ emissions by $30 \%$ and $\mathrm{VOC}$ emissions by $50 \%$ during the period 1998 to 2005 according to the Nordic action plan (OECD 2001b: 110). Projections are not available.

\subsection{Norway}

\subsubsection{Emission trends}

Table 3.4 presents the emission of $\mathrm{SO}_{2}, \mathrm{NO}_{\mathrm{X}}, \mathrm{NMVOC}$, and $\mathrm{NH}_{3}$ in Norway 1990-2006 (Norway 2008).

Table 3.4 Emission of $\mathrm{SO}_{2}, \mathrm{NO}_{x}, \mathrm{NMVOC}$, and $\mathrm{NH}_{3}$ in Norway 1990-2006 (ktonne) (Norway 2008)

\begin{tabular}{lrrrrrrrrrr}
\hline & 1990 & 1991 & 1992 & 1993 & 1994 & 1995 & 1996 & 1997 & 1998 & 1999 \\
\hline $\mathrm{SO}_{2}$ & 52.4 & 44.0 & 36.8 & 35.0 & 34.8 & 33.8 & 33.2 & 30.5 & 29.9 & 29.2 \\
$\mathrm{NO}_{x}$ & 208 & 201 & 200 & 209 & 208 & 209 & 219 & 222 & 222 & 223 \\
$\mathrm{NMVOC}$ & 295 & 295 & 324 & 341 & 354 & 368 & 370 & 368 & 362 & 370 \\
$\mathrm{NH}_{3}$ & 20.4 & 20.7 & 22.0 & 22.0 & 22.4 & 23.2 & 23.8 & 23.2 & 23.2 & 23.1 \\
\hline & 2000 & 2001 & 2002 & 2003 & 2004 & 2005 & 2006 & & & \\
\hline $\mathrm{SO}_{2}$ & 27.1 & 25.3 & 22.9 & 23.2 & 25.0 & 23.8 & 20.9 & & & \\
$\mathrm{NO}_{x}$ & 207 & 206 & 198 & 197 & 198 & 192 & 191 & & & \\
$\mathrm{NMVOC}$ & 380 & 390 & 344 & 298 & 266 & 221 & 196 & & & \\
$\mathrm{NH}_{3}$ & 23.2 & 22.7 & 22.7 & 22.8 & 22.9 & 23.0 & 22.6 & & & \\
\hline
\end{tabular}

ni: no information. 
The emissions of $\mathrm{SO}_{2}, \mathrm{NO}_{\mathrm{X}}, \mathrm{NMVOC}$ and $\mathrm{NH}_{3}$ in different sectors as well as trends are presented in Figure 3.14-3.17.
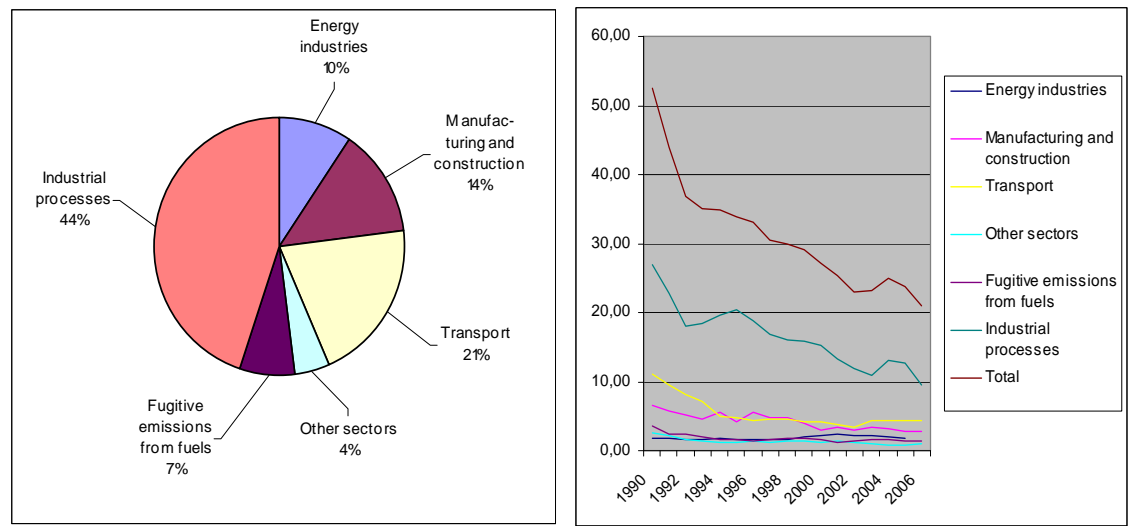

Figure 3.14. $\mathrm{SO}_{2}$ distribution (2006) and trends (ktonne) for Norway (Norway 2008)

Industrial processes are the most significant source of $\mathrm{SO}_{2}$ emission in Norway; see Figure 3.14. The emission of $\mathrm{SO}_{2}$ was reduced from 52.4 ktonne to 20.9 ktonne from 1990 to 2006 . Over the period as a whole Industrial processes contribute with approx. $50 \%$ of the total emission. Transport and Manufacturing and construction are the second most important sources as the emission from these sectors in 2006 represents 21 $\%$ and $14 \%$ of the total emission, respectively.
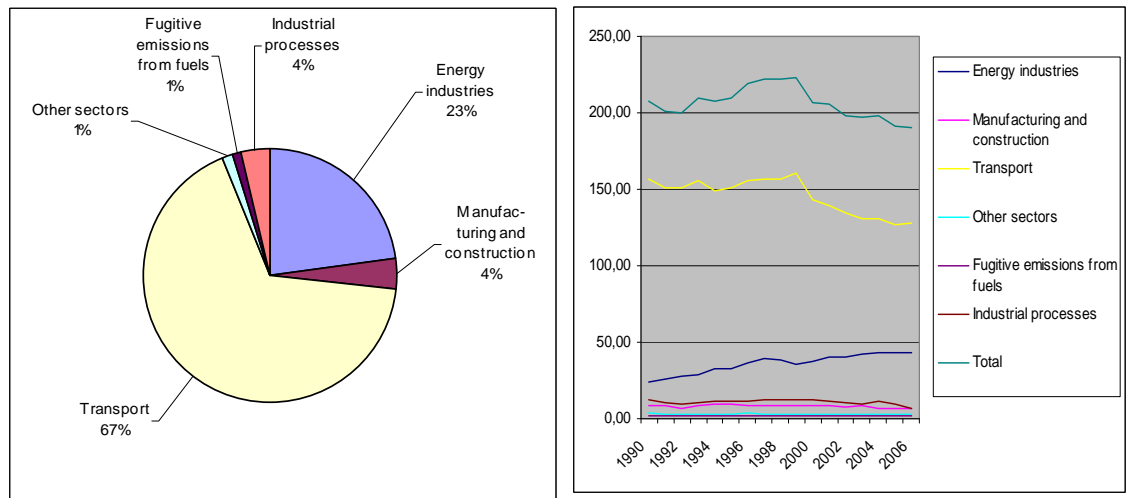

Figure 3.15. $\mathrm{NO}_{X}$ distribution (2006) and trends (ktonne) for Norway (Norway 2008)

There was only a slight reduction in the emission of $\mathrm{NO}_{\mathrm{X}}$ from 1990 to 2006 i.e. from 208 to 191 ktonne; see Figure 3.15. Transport is the most significant sector as the emission constitutes $75 \%$ of the total emission in 1990, decreasing to $67 \%$ in 2006. Energy industries are the second most significant sector, accounting for $23 \%$ of the total emission in 2006. 

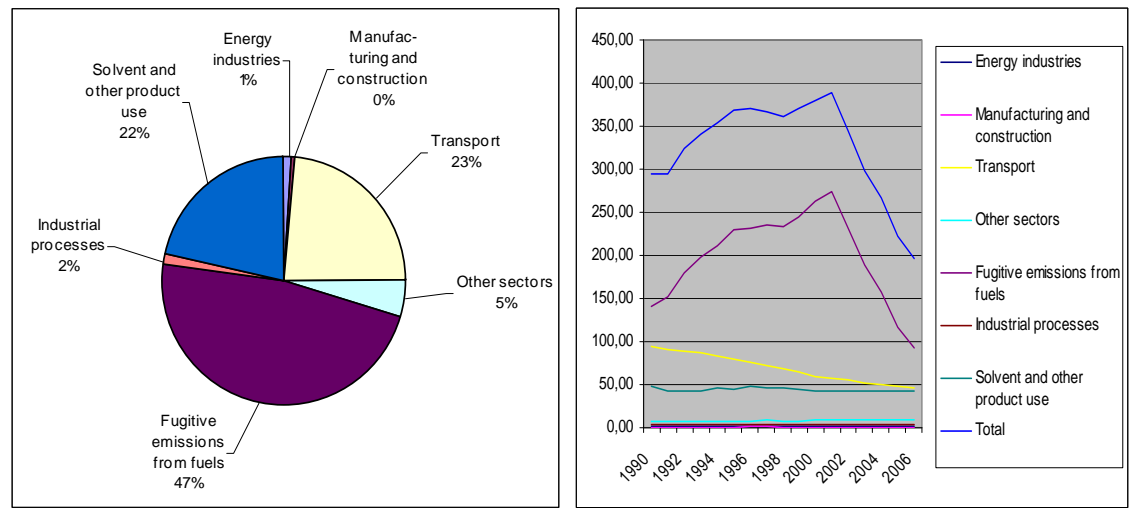

Figure 3.16. NMVOC distribution (2006) and trends (ktonne) for Norway (Norway 2008)

The emission of NMVOC decreased from 295 to 196 ktonne from 1990 to 2006, peaking at 390 ktonne in 2001; see Figure 3.16. Fugitive emissions from fuels are the most significant source followed by Transport and Solvent and other product use, accounting for $47 \%, 23 \%$ and $22 \%$ of the total emission in 2006, respectively. The distribution in 1990 was approximately the same.
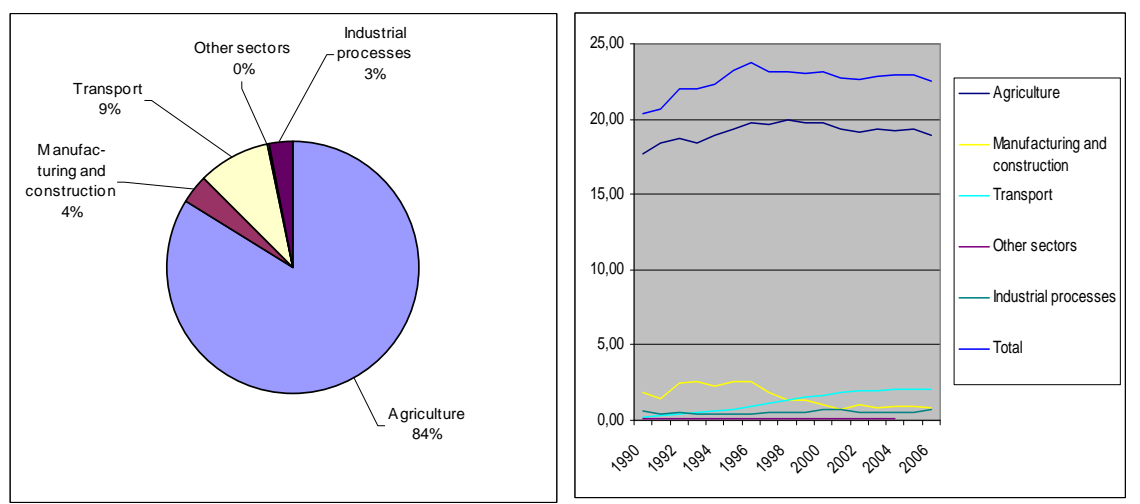

Figure 3.17. $\mathrm{NH}_{3}$ distribution (2006) and trends (ktonne) for Norway (Norway 2008)

Agriculture is the most significant source of emission of $\mathrm{NH}_{3}$ and accounts for $84 \%$ of the total emission in 2006; see Figure 3.17. During the years from 1990 to 2005 there was a slight increase from 20.4 to 22.6 ktonne $\mathrm{NH}_{3}$. Transport and Manufacturing and construction account for $9 \%$ and $4 \%$ of the total emission in 2006 .

\subsubsection{Projections and emission ceilings}

Figure 3.18 presents the latest reported 'current legislation projections' of 15.02.2007. The national emission ceilings according to the Gothenburg Protocol (UNECE, 1999) for $\mathrm{SO}_{2}, \mathrm{NO}_{\mathrm{X}}, \mathrm{NMVOC}$ and $\mathrm{NH}_{3}$ are 22, 156, 195 and 23 ktonnes, respectively. According to the latest projections Norway will not be able to meet the limit values for $\mathrm{SO}_{2}$ and $\mathrm{NO}_{\mathrm{X}}$ unless 
new measures are implemented. Especially $\mathrm{NO}_{\mathrm{X}}$ can be a problem as a reduction of $24 \%$ will be necessary for the target to be met.

TABLE IV 2A: Five-yearly, Minimum reporting of projected national total emissions of main pollutants Version 2002-1

\begin{tabular}{|c|c|c|c|c|c|c|c|}
\hline $\begin{array}{l}\text { COUNTRY: } \\
\text { DATE: } \\
\text { YEAR: }\end{array}$ & $\begin{array}{l}\text { NO } \\
13-02-2007\end{array}$ & $\begin{array}{l}\text { (as ISO2 code } \\
\text { (as DD.MM.YY } \\
\text { (as YYYY, yea }\end{array}$ & $\begin{array}{l}\text { Y) } \\
\text { f Emmi }\end{array}$ & & & & \\
\hline & UNIT & Current & gislatio & ions ${ }^{\text {a) }}$ & & reduct & \\
\hline Pollutant: & & 2010 & 2015 & 2020 & 2010 & 2015 & 2020 \\
\hline Sulphur oxides $\left(\mathrm{SO}_{\mathrm{x}}\right.$ as $\left.\mathrm{SO}_{2}\right)$ & $\mathrm{Gg}$ & 25 & & 27 & & & \\
\hline Nitrogen oxides $\left(\mathrm{NO}_{\mathrm{x}}\right.$ as $\left.\mathrm{NO}_{2}\right)$ & $\mathrm{Gg}$ & 193 & & 156 & & & \\
\hline $\begin{array}{l}\text { Non-methane volatile organic } \\
\text { compounds (NMVOC) }\end{array}$ & $\mathrm{Gg}$ & 170 & & 144 & & & \\
\hline Ammonia $\left(\mathrm{NH}_{3}\right)$ & $\mathrm{Gg}$ & 24 & & 23 & & & \\
\hline
\end{tabular}

Premilinary technical update of the NB07 projections autumn, due to methodological/ recalculations. Source: FIN og SFT

${ }^{\text {a) }}$ Current legislation projections should be based on the activity projections as reported in tables IV 2B, IV 2C, IV 2D, and IV 2E in annex IV. Note:

For the definition of 'current legislation projections' and 'current reduction plans' please refer to paragraph 24 of the guidelines (chap. V).

Figure 3.18. Report to UNECE: TABLE IV 2A: Five-yearly, Minimum reporting of projected national total emissions of main pollutants (Norway 2007)

\subsection{Sweden}

\subsubsection{Emission trends}

Table 3.5 presents the emission of $\mathrm{SO}_{2}, \mathrm{NO}_{\mathrm{X}}, \mathrm{NMVOC}$, and $\mathrm{NH}_{3}$ in Sweden 1990-2006 (Sweden 2007).

Table 3.5 Emission of $\mathrm{SO}_{2}, \mathrm{NO}_{x}, \mathrm{NMVOC}$, and $\mathrm{NH}_{3}$ in Sweden 1990-2006 (ktonne) (Sweden 2007)

\begin{tabular}{lrrrrrrrrrr}
\hline & 1990 & 1991 & 1992 & 1993 & 1994 & 1995 & 1996 & 1997 & 1998 & 1999 \\
\hline $\mathrm{SO}_{2}$ & 108 & 104 & 97 & 86 & 83 & 71 & 69 & 61.9 & 58.8 & 48.3 \\
$\mathrm{NO}_{\mathbf{X}}$ & 314 & 316 & 307 & 287 & 296 & 280 & 271 & 261 & 253 & 242 \\
$\mathrm{NMVOC}$ & 373 & 327 & 312 & 287 & 280 & 268 & 261 & 250 & 238 & 229 \\
$\mathrm{NH}_{3}$ & 54.0 & 54.0 & 54.0 & 60.0 & 60.5 & 62.0 & 59.3 & 59.6 & 58.7 & 56.3 \\
\hline & 2000 & 2001 & 2002 & 2003 & 2004 & 2005 & 2006 & & & \\
\hline $\mathrm{SO}_{2}$ & 45.9 & 44.5 & 44.7 & 45.5 & 41.2 & 39.6 & 39.3 & & & \\
$\mathrm{NO}_{x}$ & 220 & 209 & 204 & 198 & 188 & 181 & 175 & & & \\
$\mathrm{NMVOC}$ & 220 & 208 & 206 & 207 & 203 & 200 & 195 & & & \\
$\mathrm{NH}_{3}$ & 55.5 & 53.0 & 52.0 & 52.8 & 53.1 & 52.5 & 52.0 & & & \\
\hline
\end{tabular}

The emissions of $\mathrm{SO}_{2}, \mathrm{NO}_{\mathrm{X}}, \mathrm{NMVOC}$ and $\mathrm{NH}_{3}$ in different sectors as well as trends are presented in Figure 3.19-3.22. 

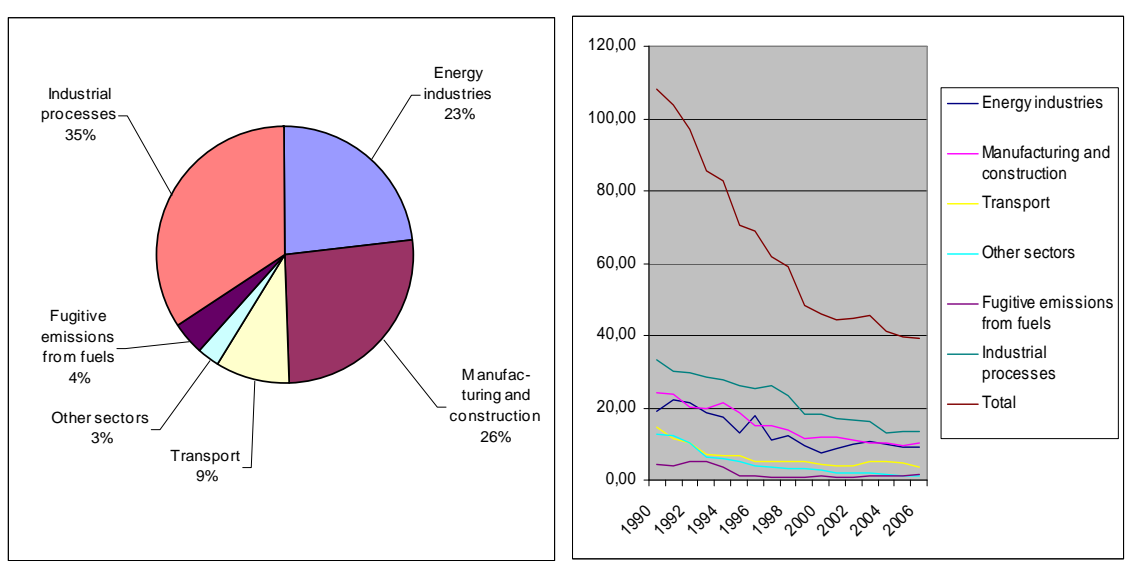

Figure 3.19. $\mathrm{SO}_{2}$ distribution (2006) and trends (ktonne) for Sweden (Sweden 2007)

The emission of $\mathrm{SO}_{2}$ reduced by $64 \%$ from 1990 to 2006; see Figure 3.19. Industrial processes, Manufacturing and construction, and Energy industries contribute with $35 \%, 26 \%$ and $23 \%$, respectively. All sectors display a decreasing trend from 1990 to 2006 .
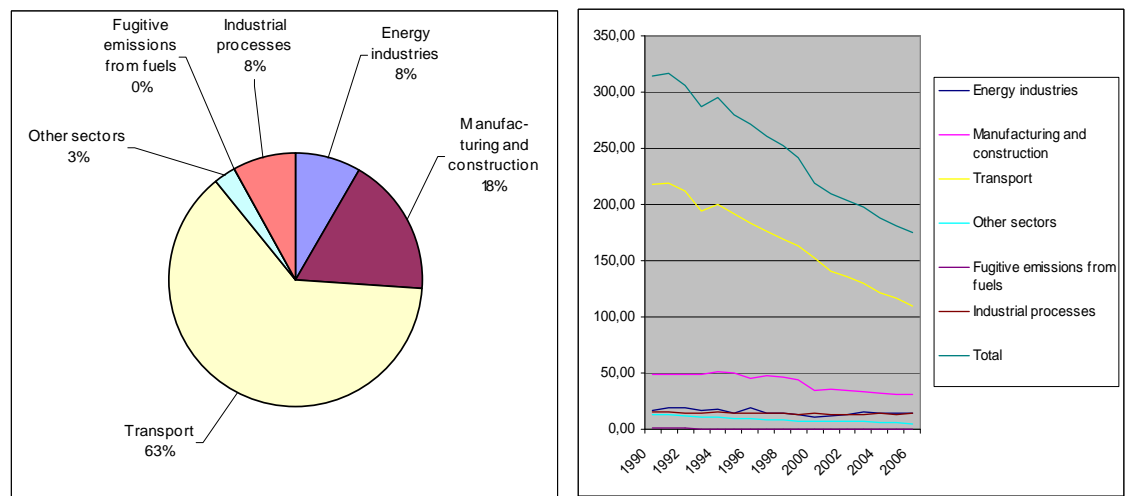

Figure 3.20. $\mathrm{NO}_{X}$ distribution (2006) and trends (ktonne) for Sweden (Sweden 2007)

Transport is the most significant source of $\mathrm{NO}_{\mathrm{X}}$ emission in Sweden; see Figure 3.20. The total emission has been reduced from 314 to $175 \mathrm{kton}-$ nes, and the contribution from transport at 63-69 \% has remained almost constant. Manufacturing and construction is the second most important sector and contributes with $18 \%$ of the total emission in 2006. Energy industries and Industrial processes each contribute with $8 \%$. 

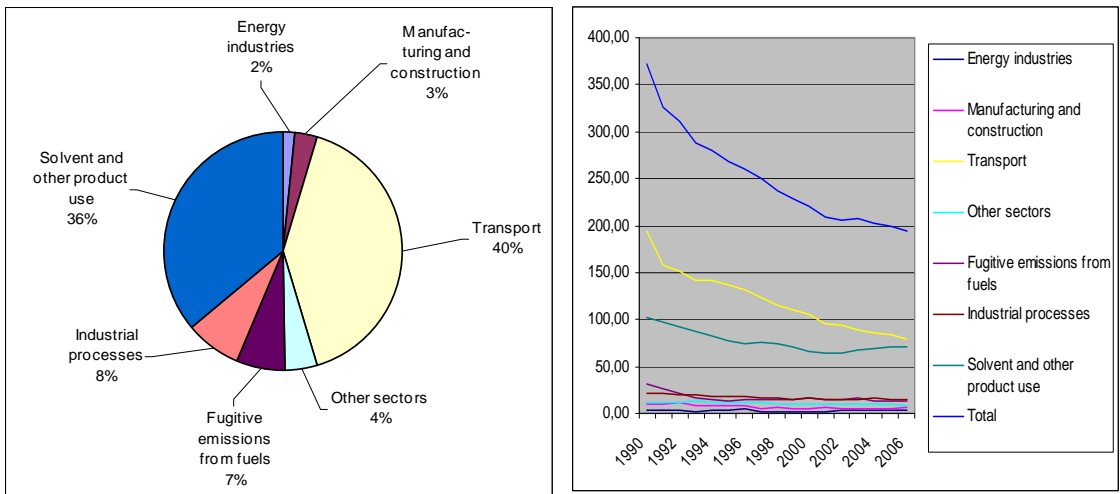

Figure 3.21. NMVOC distribution (2006) and trends (ktonne) for Sweden (Sweden 2007)

The emission of NMVOC decreased from 373 to 195 ktonne from 1990 to 2006; see Figure 3.21. Transport and Solvent and other product use are the major sources in 2006 with a contribution of $40 \%$ and $36 \%$, respectively. However, most of the overall decrease can be explained by the decrease in emissions from Transport.
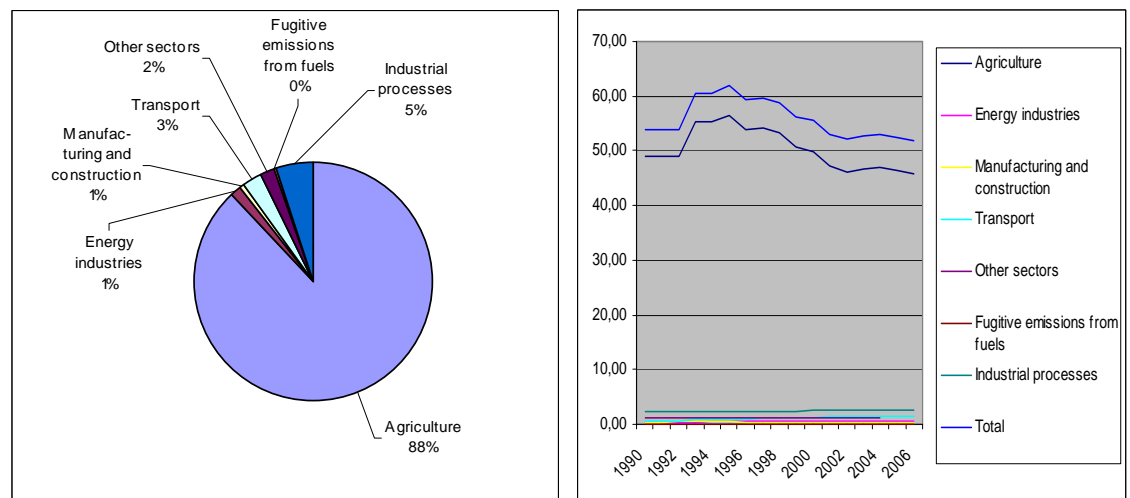

Figure 3.22. $\mathrm{NH}_{3}$ distribution (2006) and trends (ktonne) for Sweden (Sweden 2007)

The emission of $\mathrm{NH}_{3}$ in Sweden has remained almost constant reaching a maximum in 1993-1995; see Figure 3.22. Agriculture is the significant source and contributes with $88 \%$ to $91 \%$ of the total emission. Minor sources are Industrial processes, Transport and Other sectors.

\subsubsection{Projections and emission ceilings}

Figure 3.23 presents the latest reported 'current legislation projections' of 25.01.2006. The national emission ceilings according to the Gothenburg Protocol (UNECE, 1999) for $\mathrm{SO}_{2}, \mathrm{NO}_{\mathrm{X}}, \mathrm{NMVOC}$ and $\mathrm{NH}_{3}$ are 67, 148, 241 and 57 ktonne, respectively. According to the latest projections Sweden will not be able to meet the limit value for $\mathrm{NO}_{\mathrm{X}}$ unless new measures are implemented. 


\begin{tabular}{|c|c|c|c|c|c|c|c|}
\hline $\begin{array}{l}\text { COUNTRY: } \\
\text { DATE: } \\
\text { YEAR: }\end{array}$ & $\begin{array}{c}\text { SE } \\
25012006 \\
2004\end{array}$ & \multicolumn{6}{|c|}{$\begin{array}{l}\text { (as ISO2 code) } \\
\text { (as DD.MM.YYYY) } \\
\text { (as YYYY, year of Emissions) }\end{array}$} \\
\hline & UNIT & \multicolumn{3}{|c|}{ Current legislation projections ${ }^{\text {a) }}$} & \multicolumn{3}{|c|}{ Current reduction plans } \\
\hline Pollutant: & & 2010 & 2015 & 2020 & 2010 & 2015 & 2020 \\
\hline Sulphur oxides $\left(\mathrm{SO}_{\mathrm{x}}\right.$ as $\left.\mathrm{SO}_{2}\right)$ & $\mathrm{Gg}$ & 33 & 30 & 29 & & $\mathrm{NE}$ & $\mathrm{NE}$ \\
\hline Nitrogen oxides $\left(\mathrm{NO}_{\mathrm{x}}\right.$ as $\left.\mathrm{NO}_{2}\right)$ & Gg & 154 & $\mathrm{NE}$ & 119 & & $\mathrm{NE}$ & $\mathrm{NE}$ \\
\hline $\begin{array}{l}\text { Non-methane volatile organic } \\
\text { compounds (NMVOC) }\end{array}$ & $\mathrm{Gg}$ & 183 & 176 & 166 & & $\mathrm{NE}$ & $\mathrm{NE}$ \\
\hline Ammonia $\left(\mathrm{NH}_{3}\right)$ & $\mathrm{Gg}$ & 50 & $\mathrm{NE}$ & $\mathrm{NE}$ & & $\mathrm{NE}$ & $\mathrm{NE}$ \\
\hline
\end{tabular}

${ }^{\text {a) }}$ Current legislation projections should be based on the activity projections as reported in tables IV 2B, IV 2C, IV 2D, and IV 2E in annex IV. Note:

Note:
For the definition of 'current legislation projections' and 'current reduction plans' please refer to paragraph 24 of the guidelines (chap. V). Figure 3.23. Report to UNECE: TABLE IV 2A: Five-yearly, Minimum reporting of projected national total emissions of main pollutants (Sweden 2007)

NE: Not estimated

\subsection{Summary}

\subsubsection{Emission ceilings}

The previous sections present emission trends for $\mathrm{SO}_{2}, \mathrm{NO}_{\mathrm{X}}, \mathrm{NMVOC}$ and $\mathrm{NH}_{3}$ as well as the distribution between different sectors, for Denmark, Finland, Iceland, Norway and Sweden. Table 3.6 summarizes the national projections for 2010 compared with the emission ceilings according to the Gothenborg Protocol (UNECE, 1999). Iceland has only ratified the Convention (UNECE, 1979) and not the Gothenburg Protocol (UNECE, 1999), and is therefore not included in the table.

According to the current projections Norway, Denmark and Sweden will not be able to meet the limit values for $\mathrm{NO}_{\mathrm{X}}$. The distance from the targets is 37, 9 and 6 ktonne, respectively, representing $24 \%, 7 \%$ and 4 $\%$ of the targets.

Denmark will not be able to meet the limit value for NMVOC according to the current projection and can be expected to exceed the limit value by 3 ktonne. The excess constitutes $4 \%$ of the target.

Norway will not be able to meet the limit value $\mathrm{SO}_{2}$ according to the present projection and can be expected to exceed the limit value with 3 ktonne. The excess constitutes $14 \%$ of the target.

According to the current projections Finland can be expected to meet all four emission ceilings. 
Table 3.6 National projections for $\mathrm{SO}_{2}, \mathrm{NO}_{x}, \mathrm{NMVOC}$ and $\mathrm{NH}_{3}$ for Denmark, Finland, Norway and Sweden compared with the national emission ceilings (Denmark 2007, Finland 2007b, Norway 2007, Sweden 2007, UNECE 1999)

\begin{tabular}{|c|c|c|c|c|c|c|}
\hline & Pollutant: & Unit & 2010 & Gothenburg & NEC/Other & $\begin{aligned} \text { tance to } \\
\text { target }^{2}\end{aligned}$ \\
\hline \multirow[t]{4}{*}{ Denmark } & Sulphur oxides $\left(\mathrm{SO}_{\mathrm{x}}\right.$ as $\left.\mathrm{SO}_{2}\right)$ & $\mathrm{Gg}$ & 20 & 55 & & 35 \\
\hline & Nitrogen oxides $\left(\mathrm{NO}_{x}\right.$ as $\left.\mathrm{NO}_{2}\right)$ & $\mathrm{Gg}$ & 136 & 127 & & -9 \\
\hline & $\begin{array}{l}\text { Non-methane volatile organic com- } \\
\text { pounds (NMVOC) }\end{array}$ & $\mathrm{Gg}$ & 88 & 85 & & -3 \\
\hline & Ammonia $\left(\mathrm{NH}_{3}\right)$ & $\mathrm{Gg}$ & 65 & 69 & & 4 \\
\hline \multirow[t]{5}{*}{ Finland } & Sulphur oxides $\left(\mathrm{SO}_{\mathrm{x}}\right.$ as $\left.\mathrm{SO}_{2}\right)$ & $\mathrm{Gg}$ & 98 & 116 & $110^{1}$ & 19 \\
\hline & Nitrogen oxides $\left(\mathrm{NO}_{x}\right.$ as $\left.\mathrm{NO}_{2}\right)$ & $\mathrm{Gg}$ & 151 & 170 & & 19 \\
\hline & Non-methane volatile organic com- & & & 120 & & \\
\hline & pounas (IVIVIVUC) & $\mathrm{Gg}$ & 130 & 130 & & 0 \\
\hline & Ammonia $\left(\mathrm{NH}_{3}\right)$ & $\mathrm{Gg}$ & 31 & 31 & & 0 \\
\hline \multirow[t]{5}{*}{ Norway } & Sulphur oxides $\left(\mathrm{SO}_{x}\right.$ as $\left.\mathrm{SO}_{2}\right)$ & $\mathrm{Gg}$ & 25 & 22 & & -3 \\
\hline & Nitrogen oxides $\left(\mathrm{NO}_{x}\right.$ as $\left.\mathrm{NO}_{2}\right)$ & $\mathrm{Gg}$ & 193 & 156 & & -37 \\
\hline & Non-methane volatile organic com- & & & & & \\
\hline & pounds (NMVOC) & $\mathrm{Gg}$ & 170 & 195 & & 25 \\
\hline & Ammonia $\left(\mathrm{NH}_{3}\right)$ & $\mathrm{Gg}$ & 24 & 23 & & -1 \\
\hline \multirow[t]{5}{*}{ Sweden } & Sulphur oxides $\left(\mathrm{SO}_{x}\right.$ as $\left.\mathrm{SO}_{2}\right)$ & $\mathrm{Gg}$ & 33 & 67 & & 34 \\
\hline & Nitrogen oxides $\left(\mathrm{NO}_{x}\right.$ as $\left.\mathrm{NO}_{2}\right)$ & $\mathrm{Gg}$ & 154 & 148 & & -6 \\
\hline & Non-methane volatile organic com- & & & & & \\
\hline & pounds (NMVOC) & $\mathrm{Gg}$ & 183 & 241 & & 58 \\
\hline & Ammonia $\left(\mathrm{NH}_{3}\right)$ & $\mathrm{Gg}$ & 50 & 57 & & 7 \\
\hline
\end{tabular}

1. Mareckova et al. (2007)

2. A negative number indicates that the projected emission exceeds the target.

Table 3.7 presents the sectors in each country contributing more than 20 $\%$ to the total national emission for the respective substance.

Table 3.7 Sectors contributing more than $\mathbf{2 0} \%$ to the total national emission in the Nordic countries in 2006 (Iceland in 2004)

\begin{tabular}{|c|c|c|c|c|}
\hline & $\mathrm{SO}_{2}$ & $\mathrm{NO}_{\mathrm{x}}$ & NMVOC & $\mathrm{NH}_{3}$ \\
\hline \multirow[t]{2}{*}{ Denmark } & Energy industries & Transport & Transport & Agriculture \\
\hline & $\begin{array}{l}\text { Manufacturing and } \\
\text { construction }\end{array}$ & Energy industries & $\begin{array}{l}\text { Solvent and other } \\
\text { product use }\end{array}$ & \\
\hline \multirow[t]{3}{*}{ Finland } & Energy inustries & Transport & Transport & Agriculture \\
\hline & $\begin{array}{l}\text { Manufacturing and } \\
\text { construction }\end{array}$ & Energy industries & Other sectors & \\
\hline & & $\begin{array}{l}\text { Manufacturing and } \\
\text { construction }\end{array}$ & $\begin{array}{l}\text { Solvent and other } \\
\text { product use }\end{array}$ & \\
\hline \multirow[t]{2}{*}{ Iceland } & Industrial processes & Other sectors & Transport & na \\
\hline & & & $\begin{array}{l}\text { Solvent and other } \\
\text { product use }\end{array}$ & na \\
\hline \multirow[t]{2}{*}{ Norway } & Industrial processes & Transport & $\begin{array}{l}\text { Fuggitive emissions } \\
\text { from fuels }\end{array}$ & Agriculture \\
\hline & & Energy industries & Transport & \\
\hline \multirow[t]{3}{*}{ Sweden } & Industrial processes & Transport & Transport & Agriculture \\
\hline & $\begin{array}{l}\text { Manufacturing and } \\
\text { construction }\end{array}$ & & $\begin{array}{l}\text { Solvent and other } \\
\text { product use }\end{array}$ & \\
\hline & Energy industries & & & \\
\hline
\end{tabular}

na: not analysed 


\subsection{2 $\mathrm{SO}_{2}$}

In Denmark and Finland the most significant $\mathrm{SO}_{2}$ sources are Energy industries and energy consumption in Manufacturing and construction. The sulphur content of fuel determines the level of the emission of $\mathrm{SO}_{2}$; and reductions in the sulphur content of fuel combined with introduction of flue gas cleaning equipment/desulphurization has caused the emission decrease from 1990 to 2006. For Iceland, Norway and Sweden, Industrial processes are the most significant source followed by Energy industries and Manufacturing and construction.

\subsection{3 $\mathrm{NO}_{X}$}

Emission of $\mathrm{NO}_{\mathrm{X}}$ is mainly an output from combustion processes/high temperature processes. For all the Nordic countries except Iceland Transport is the most important source. Energy industries/Manufacturing and construction are the next most important. The majority of power plants have been fitted with de- $\mathrm{NO}_{\mathrm{X}}$ equipment.

\subsubsection{NMVOC}

Transport is a significant source of the emission of NMVOC in all the Nordic countries; however, Solvent and other product use and Fugitive emissions from fuels also contribute with considerable amounts of NMVOC emission.

\subsection{5 $\mathrm{NH}_{3}$}

Agriculture is the only important source regarding emission of $\mathrm{NH}_{3}$. For Iceland no inventory for $\mathrm{NH}_{3}$ is available. 



\section{Meta-evaluation of applied policy instruments}

How should we interpret the declines in emissions that have been or will be accomplished according to the data presented in the previous section? While it is tempting to credit the international protocols with the emission reductions, in reality their role comprises only part of the story. There are underlying structural changes in energy supply systems and transport patterns which are relatively autonomous of any measures introduced by individual countries to reduce emissions. Secondly, the approaches applied in the individual countries differ with respect to the measures introduced to curb emissions, especially with respect to the policy instruments employed. Third but not least, the various substances have different physical and chemical properties which affect the mitigation options available and, ultimately, the pattern of emissions reductions.

Figure 4.1 and 4.2 below illustrate the marked difference in reduction patterns for $\mathrm{SO}_{2}$ and $\mathrm{NO}_{\mathrm{X}}$ which have been identified (Wuester 2001). The patterns, moreover, are remarkably similar in several European countries, including the Nordic countries. For $\mathrm{SO}_{2}$ use of scrubbers has been widespread, and while this control technology has contributed significantly to curbing emissions, so have fuel shifts in the energy sectors as well as changes in the technologies implemented within individual sectors. For $\mathrm{NO}_{\mathrm{X}}$ the pattern is fundamentally different in that technological and structural factors apparently play a more modest role, and the main reductions stem from control measures introduced predominantly end-ofpipe.

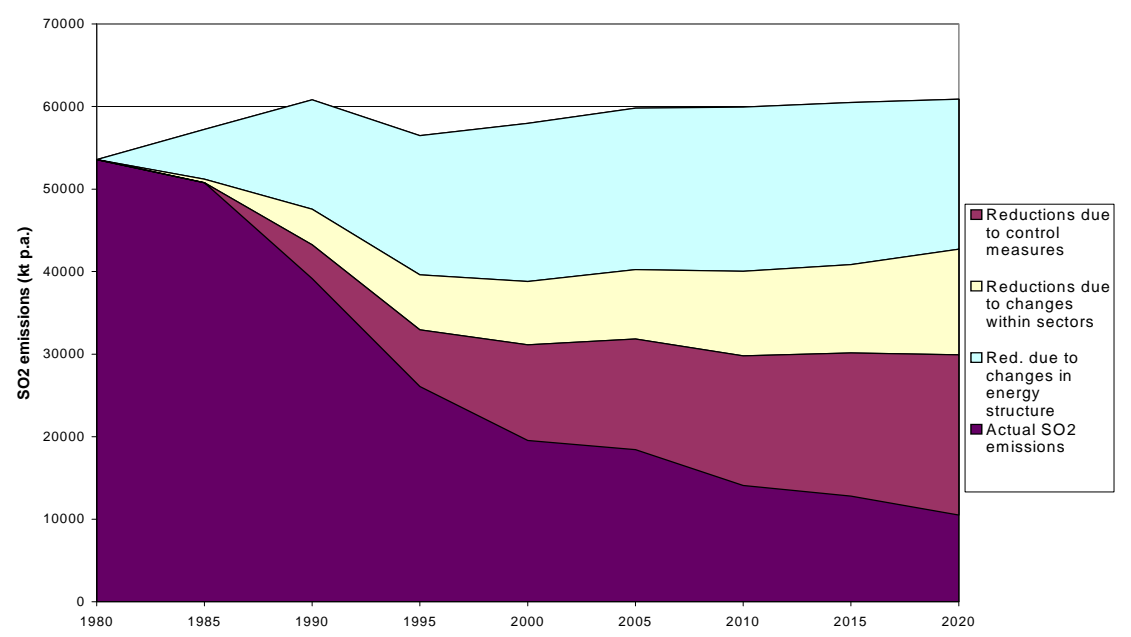

Figure 4.1. Decomposition of European $\mathrm{SO}_{2}$ Emissions 1980-2020 (Wuester, 2001) 


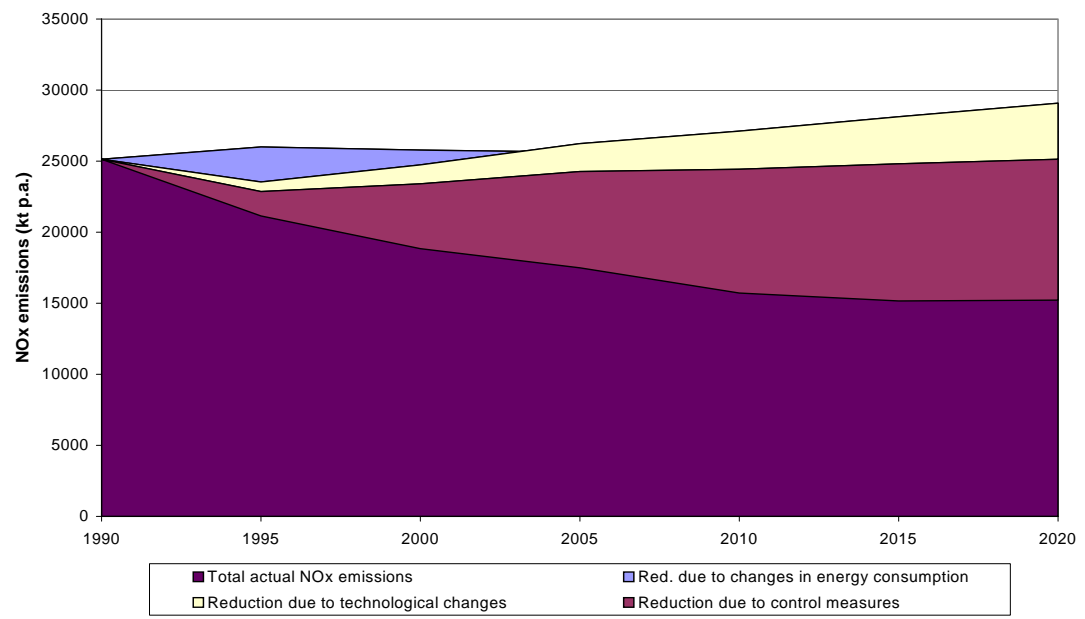

Figure 4.2. Decomposition of European $\mathrm{NO}_{X}$ Emissions 1990-2020 (Wuester, 2001)

The disparte abatement profiles for $\mathrm{SO}_{2}$ and $\mathrm{NO}_{\mathrm{X}}$ may to some extent reflect the different emphasis within past emission control; sulphur became subject to control early on under the 1985 Sulphur Protocol, whereas with respect to $\mathrm{NO}_{\mathrm{x}}$ focus was initially on stabilization rather than reduction. However, with the Gothenburg Protocol it was agreed to introduce emissions ceilings that, for most countries, entailed the requirement to reduce $\mathrm{NO}_{\mathrm{X}}$ and other emissions. With respect to $\mathrm{NO}_{\mathrm{X}}$ attainment of the ceilings has proved problematic. In order to improve the design of future regulations in the field of air pollution control, we need an improved understanding of existing abatement policies as well as the role of the various mitigation measures.

Figure 4.3 illustrates that it is necessary both to consider anticipated and unanticipated effects, and to consider effects within as well as outside the target area. Effects outside the target area can be termed 'side effects' (for a more detailed discussion of evaluation of environmental policy, see e.g. Hildén et al. 2002; Mickwitz 2003).

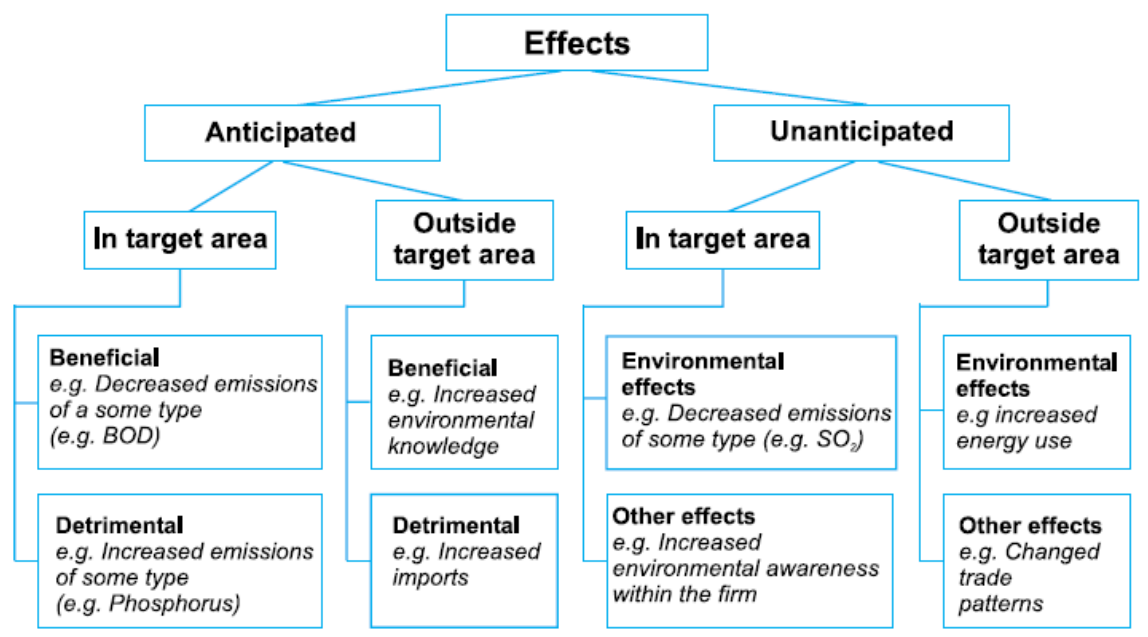

Figure 4.3. Different types of effects (Hildén et al. 2002: 15) 


\subsection{Literature review}

In the following literature review we focus on policy impact evaluations targeted at the four pollutants in the Gothenburg Protocol. The purpose is to provide an overview of what is known about the effectiveness of the Gothenburg Protocol and the instruments and factors that have been instrumental in the emission declines. We include some studies that cover carbon-energy taxes because of the increased importance attached to consideration of air pollution control and climate mitigation policy instruments as intimately related, and because emissions, to a large extent, have been influenced by developments in the energy sector. It is beyond the scope of the present project to undertake a comprehensive disentanglement of the emission reductions in relation to the relative contributions of various policy instruments, but the literature review presented below can be seen as a stepping stone in this direction. Moreover, it appears that data and methods are indeed available for a more ambitious analysis of this kind.

\subsection{Cost-effectiveness and policy instruments}

The initial phase of air pollution protocols in the 1980s adopted flat-rate numerical reduction obligations, which were criticized for their lack of cost-effectiveness. The current phase, however, with the Gothenburg Protocol and the NEC Directive, is based in principle on the critical load concept and the RAINS model, and the detrimental effects have been translated into national emissions ceilings in terms of least-cost optimization.

As part of the EU's Clean Air for Europe process a new conceptual method has been developed which replaces the critical load approach with a more straightforward cost-benefit assessment. Whereas the critical load approach was ecosystem-related, the new cost-benefit assessment attributes human health impacts a greater role. Factoring in benefits in monetary terms is an innovative approach, and it should presumably allow decision-makers to improve the economic efficiency of air pollution control (Harrington and Morgenstern, 2004; OECD, 2007: 119ff).

In the review of measures and policy instruments we emphasise costeffectiveness aspects, as these play a key role in the public debate. As the potential benefits oppose the damage costs, where possible we consider policy instruments and efforts where a price tag has been attached to emissions - either directly as an emissions tax or more indirectly affecting polluting activities. 


\subsection{General evaluations}

\section{Centre for Integrated Assessment (CIAM 2007)}

In this evaluation it is assessed that the majority of the emission ceilings for the parties to the Gothenburg Protocol will be reached by 2007. Overall, emissions of all pollutants concerned have shown a downward trend since 1999. However, half of the countries under the protocol - including Denmark, Norway, and Sweden - need to introduce additional measures in order to reach the $\mathrm{NO}_{\mathrm{X}}$ goal. Emissions in countries that have not signed the protocol are projected to increase in years to come (ibid: 33ff).

In general, deposition of acidifying substances has decreased substantially, but current deposition is still well above levels where ecosystem recovery can be guaranteed. Slow progress in reducing nitrogen deposition brings with it the risk of loss of biodiversity. Additionally, there has only been limited progress with regard to reduction of ground-level ozone (ibid: 26).

A process goal of the Gothenburg Protocol was that the protocol should lead to more cost-effective emission reductions due to ceilings that are set individually for each country. According to the evaluation, the protocol could have been more cost-effective. First, the negotiated ceilings of the protocol deviate by up to $10-20 \%$ in relation to the calculations in the cost-optimization analysis. Second, the cost curves in the RAINS model did not take the potential for structural changes in the energy sector, transportation, and agriculture into account (ibid: 36). Furthermore, total costs could be lowered if additional abatement measures are implemented for ships; potential emission reductions in non-EU countries are taken into account; and additional measures are taken to combat greenhouse gas emissions.

\section{Andersen et al. (2007a)}

In this comprehensive ex post project within the Sixth EU Framework Programme, the effects of environmental tax reforms (regarding energy and $\mathrm{CO}_{2}$ taxes) are assessed for different industries in a number of European countries. For instance, the analyses show that the burden of environmental tax reform for energy-intensive sectors (metal, cement, glass, etc), net of the value of exemptions and reductions, did not exceed $5 \%$ of gross operating surplus in any sector in the countries analysed. Furthermore, within the period analysed, the net costs of environmental tax reform are, in most sectors, exceeded by the value of the gains in energy efficiency, and the positive impacts of revenue recycling (Andersen et al. 2007a: 67). Analysis carried out by Cambridge Econometrics in the project on the basis of the E3ME model provides estimates for changes in fuel use and the fuel mix in the energy and transport sectors. In principle, 
relevant impacts from conventional air pollutants could be derived from this data.

\subsection{Denmark}

Regulation of air pollution in Denmark is found in the Danish Environmental Protection Act. The act's licensing system regulates atmospheric and other emissions from stationary sources (OECD 1999: 75). Most Danish emission sources have been under (command-and-control) regulation since the early 1970s (Heidam \& Illerup 2004).

Denmark has successfully operated a system of $\mathrm{SO}_{2}$ and $\mathrm{NO}_{\mathrm{X}}$ quotas for the largest power plants since the mid-1980s (Danish Energy Authority 2007). Furthermore, Denmark has a system of excise duties on fossil fuels (Speck et al. 2006: 61).

OECD (2008: 30) concludes that the Danish emission of $\mathrm{NO}_{\mathrm{X}}, \mathrm{SO}_{\mathrm{X}}$ and VOC has been 'strongly decoupled from economic growth' over the last decade, and $\mathrm{NH}_{3}$ has also decreased. The prime challenges lying ahead are $\mathrm{NO}_{\mathrm{X}}$ (still) and $\mathrm{PM}$ emissions - one fifth of Danes are exposed to unacceptable levels of air pollution. However, a new programme involving 'low emission zones' was implemented in Copenhagen in January 2007 (ibid: 38 ).

The Danish $\mathrm{SO}_{2}$ emission intensity (emission per unit of GDP) is now the lowest among the OECD countries - due partly to the $\mathrm{SO}_{2}$ tax introduced 1996. Fuels with a sulphur content above $500 \mathrm{ppm}$ are subject to a $\mathrm{SO}_{2}$ tax of $20 \mathrm{DKK}\left(€ 2.7^{2008}\right) / \mathrm{kg}$ sulphur and release of $\mathrm{SO}_{2}$ emissions to air is taxed at $10 \mathrm{DKK}\left(€ 1.3^{2008}\right) / \mathrm{kg}$ sulphur. As far as techological measures are concerned, the large $\mathrm{SO}_{2}$ reduction is mainly due to installation of desulphurization equipment and use of fuels with lower sulphur content in public power and district heating plants (OECD 2008: 35-41).

Regarding $\mathrm{NO}_{\mathrm{X}}$, transport is the sector that contributes most to the current emission level. In recent years, large infrastructure projects have led to significant increases in road freight transport. Progress with regard to $\mathrm{NO}_{\mathrm{X}}$ emission reduction has been due to stricter vehicle exhaust emissions standards, and improvements in power and district heating plants with installation of low- $\mathrm{NO}_{\mathrm{X}}$ burners and de-nitrifying units (ibid: 37, 41). Danish taxes on gasoline and diesel fuels are somewhat lower than in other EU countries, while taxes associated with car ownership are heavy (ibid: 43).

While $\mathrm{NO}_{\mathrm{X}}$ emissions have declined, $\mathrm{NO}_{2}$ emissions have been rising - e.g. due to an increase in the number of diesel cars (see e.g. Slentø et al. 2008).

Recently, the Danish government decided to introduce a $\mathrm{NO}_{\mathrm{X}}$ tax on stationary sources onshore and offshore at DKK $5 / \mathrm{kg}\left(€ 0.7^{2008}\right)$ from 2010, with reimbursement of the revenue (Ministry of Taxation 2007). 
Almost all atmospheric emissions of $\mathrm{NH}_{3}$ result from agricultural activities. In particular, the three successive Danish action plans for the aquatic environment, and the ammonia action plan have contributed to a lowering of $\mathrm{NH}_{3}$ emissions (OECD 2008: 37).

Danish VOC emissions in particular originate from incomplete combustion processes (in road vehicles, sea vessels, off-road machinery, etc.). However, emissions have declined since the introduction of catalytic converters to cars in 1990, and since the implementation of Directive 1999/13/EC regarding reduced EU emissions from the use of solvents.

\section{Ministry of Finance (1999)}

Ministry of Finance (1999) evaluates a number of different green taxes introduced in Denmark during the 1990s, the $\mathrm{SO}_{2}$ tax being one of them. The $\mathrm{SO}_{2}$ tax was introduced in 1995 as part of an 'energy package' which also contained revision of the $\mathrm{CO}_{2}$ tax and the energy tax. The $\mathrm{SO}_{2}$ tax was introduced incrementally during the years 1996-2000. Only fuels with more than $0.05 \%$ sulphur are taxed, which exempts gas oil and gas from the tax. On the other hand, wood, waste, coal, etc. are embraced by the tax. The tax level was $10 \mathrm{DKK} / \mathrm{kg} \mathrm{SO}_{2}\left(€ 1.3^{2008}\right)$ (and remains at this level in 2007). Regarding $\mathrm{SO}_{2}$ the analysis is primarily ex ante. It is forecasted that the tax will reduce $\mathrm{SO}_{2}$ emissions by 34,000 tonnes per year by 2005 (ibid: 45). This calculation is based on introduction of cleaner technology and a lowering of the sulphur content in various fuels. Furthermore, a substitution effect involving switches to fuels with low sulphur content is expected. Revenue from the 'energy package' was reimbursed to the companies affected through a lowering of other taxes and fees.

Palmgren et al. (2005a)

As part of this study of Danish particle pollution, an ex ante analysis of the introduction of particle filters in heavy goods vehicles in an environment zone in Copenhagen was carried out. We mention the study here, because introduction of particle filters will probably lead to more $\mathrm{NO}_{\mathrm{X}}$ pollution (see Palmgren et al. 2007, below). On the other hand, there will be very considerable positive effects on $\mathrm{PM}_{2.5}$ pollution. The cost of introducing environmental zones is estimated at approx. DKK 80 million/year $\left(€ 10.7\right.$ million $\left.^{2005}\right)$, and the positive effects on health are calculated at approx. DKK 160 million/year $\left(€ 21.5\right.$ million $\left.^{2005}\right)$. The welfare economic surplus is thereby DKK 80 million/year $\left(€ 10.7\right.$ million $\left.^{2005}\right)$. The calculation shows that an environmental zone can prevent in the region of 20-90 excess deaths in the metropolitan area on an annual basis (see also Palmgren et al., 2005b). 


\section{Environmental Protection Agency $(2006 a+b)$}

These reports analyse (ex ante) how to reach the Danish $\mathrm{NO}_{\mathrm{X}}$ reduction ceiling (127,000 tonne) in 2010 in the most cost effective way. During the period 1985 to 2004 emissions fell from 293,000 tonne to 181,000 tonne. A further 47,000 tonne reduction was expected in the period 2004 to 2010, leaving Denmark an expected 7,000 tonne short of the ceiling in 2010 .

However, 7,000 tonne represents a narrowing of the shortfall over the 2004 estimate, where a prognosis showed that Denmark would fall 40,000 tonne short of the $\mathrm{NO}_{\mathrm{X}}$ ceiling. According to the Danish Environmental Protection Agency (2006a: 7), the recent improvement is due to the government's energy strategy, the energy saving plan, energy tax reform, and the installation of $\mathrm{NO}_{\mathrm{X}}$ reducing equipment in power plants.

In general there are two options when trying to minimize $\mathrm{NO}_{\mathrm{X}}$ emissions:

- promote emission reduction technology

- force a fuel/energy source change (e.g. from coal to wind powered electricity)

The most cost-effective ways to lower Danish emissions (see Table 4.1) by a further 7,000 tonnes would be to:

- install catalysts (SCR - Selective Catalytic Reduction) on fishing vessels

- change to low- $\mathrm{NO}_{\mathrm{X}}$ burners on boilers in industry with gas or gasoline

- improve distribution gear on gas turbines in the power production sector 
Table 4.1 $\mathrm{NO}_{\mathrm{x}}$-reducing measures (ranked according to cost effectiveness)

\begin{tabular}{|c|c|c|c|c|c|}
\hline Measure & Sector & $\begin{array}{r}\text { NOX reduc- } \\
\text { tion } 2010 \\
\text { (tonne) }\end{array}$ & $\begin{array}{r}\text { DKK per kg } \\
\text { reduced NOX } \\
\text { (shadow price) }\end{array}$ & $\begin{array}{r}\text { Accumulated NOX } \\
\text { reduction in } 2010 \\
\text { (tonne) }\end{array}$ & $\begin{array}{r}\text { Accumulated average } \\
\text { cost per kg reduced NOX } \\
\text { (shadow price) }\end{array}$ \\
\hline $\begin{array}{l}\text { SCR on fishing } \\
\text { vessels } 2\end{array}$ & Fishery & 4511 & 3 & 4511 & 3 \\
\hline $\begin{array}{l}\text { Low-NOX burners in } \\
\text { industrial boilers, gas } \\
\text { oil }\end{array}$ & Industry & 704 & 8 & 5215 & 3 \\
\hline $\begin{array}{l}\text { Low-NOX burners in } \\
\text { industrial boilers, gas }\end{array}$ & Industry & 665 & 10 & 5880 & 4 \\
\hline $\begin{array}{l}\text { Better distribution } \\
\text { gear at CHP plants }\end{array}$ & $\mathrm{CPH}$ & 1685 & 11 & 7565 & 6 \\
\hline $\begin{array}{l}\text { Reburning wood } \\
\text { chips and wood }\end{array}$ & $\mathrm{CPH}$ & 211 & 31 & 7775 & 6 \\
\hline Reburning straw & $\mathrm{CPH}$ & 165 & 37 & 7941 & 7 \\
\hline $\begin{array}{l}\text { SCR on tractors and } \\
\text { combined harvesters }\end{array}$ & $\begin{array}{l}\text { Other mobile } \\
\text { sources }\end{array}$ & 3111 & 53 & 11052 & 20 \\
\hline $\begin{array}{l}\text { Advanced reburning } \\
\text { of coal }\end{array}$ & $\mathrm{CPH}$ & 82 & 61 & 11134 & 20 \\
\hline $\begin{array}{l}\text { DLE on two gas } \\
\text { turbines }(8,9)\end{array}$ & Offshore & 743 & 64 & 11877 & 23 \\
\hline $\begin{array}{l}\text { SCR on heavy } \\
\text { vehicles }\end{array}$ & Transport & 3279 & 72 & 15156 & 34 \\
\hline $\begin{array}{l}\text { DLE on a gas turbine } \\
\text { (4) }\end{array}$ & Offshore & 661 & 78 & 15817 & 35 \\
\hline Advancing EURO 5 & Transport & 359 & 91 & 16176 & 37 \\
\hline $\begin{array}{l}\text { DLE on seven gas } \\
\text { turbines }(3,1,14 \text {, } \\
16,10,7,18)\end{array}$ & Offshore & 1988 & 131 & 18164 & 47 \\
\hline Offshore windmills & $\begin{array}{l}\text { Renewable } \\
\text { energy }\end{array}$ & 195 & 208 & 18359 & 49 \\
\hline $\begin{array}{l}\text { DLE in one gas } \\
\text { turbine (17) }\end{array}$ & Offshore & 388 & 241 & 18747 & 53 \\
\hline $\begin{array}{l}\text { Advancing EURO } 6 \\
\text { by } 3 \text { years }\end{array}$ & Transport & 193 & 271 & 18941 & 55 \\
\hline $\begin{array}{l}\text { DLE on four gas } \\
\text { turbines }(11,12,13 \text {, } \\
5)\end{array}$ & Offshore & 373 & 280 & 19314 & 59 \\
\hline $\begin{array}{l}\text { Partial boosting at } \\
\text { CHP plants }\end{array}$ & Power plants & 957 & 312 & 20271 & 71 \\
\hline $\begin{array}{l}\text { DLE in two gas } \\
\text { turbines }(19,15)\end{array}$ & Offshore & 171 & 339 & 20442 & 73 \\
\hline $\begin{array}{l}\text { Change from diesel } \\
\text { to petrol cars }\end{array}$ & Transport & 106 & 444 & 20548 & 75 \\
\hline $\begin{array}{l}\text { DLE in one gas } \\
\text { turbine (2) }\end{array}$ & Offshore & 48 & 521 & 20596 & 76 \\
\hline
\end{tabular}

Source: Environmental Protection Agency (2006a: 53, 57).

- SCR=Selective Catalytic Reduction. - DLE=Dry Low Emission - It is possible to install DLE technology in 18 gas turbines in the offshore sector. There is a huge variation in the costs attached to different turbines. Therefore, the cost effectiveness differs for DLE. - Some measures have been omitted from the table because they are mutually exclusive with more cost effective measures (Environmental Protection Agency 2006a: 56)

${ }^{2}$ The Danish Environmental Protection Agency has recently obtained new information on the expected costs from installing catalysts on fishing vessels, which are significantly higher than the costs estimates presented in the 2006 reports. 
For these measures, total costs to businesses (primarily the energy sector, but also fisheries and industry) amount to DKK 32 million ( $€ 4.3$ million $^{2006}$ ) (over 30 years), while the Danish state will receive a revenue of DKK 6 million ( $€ 0.8$ million $^{2006}$ ) (ibid: 56). A cost-benefit analysis of the measures, including the welfare economic benefits, shows a net benefit of their implementation amounting to DKK 6 billion ( $€ 0.8$ billion $^{2006}$ ) (ibid: 48). It is to be underlined, though, that the uncertainties present in the analysis are considerable. Table 4.1 shows the costs for the different measures.

It is evident from the table that the 7,000 tonne shortfall, mentioned above, can be made up by implementing the first four measures, which would entail a reduction in $\mathrm{NO}_{\mathrm{X}}$ of 7,565 tonne. The cost of each of these four measures ranges from DKK 3 to DKK $11\left(€ 0.4-1.5^{2006}\right)$ per $\mathrm{kg}$ of reduction of $\mathrm{NO}_{\mathrm{X}}$. The average cost of these four measures is DKK 6 $\left(€ 0.8^{2006}\right) / \mathrm{kg}$ reduction of $\mathrm{NO}_{\mathrm{X}}$.

The Danish National Environmental Research Institute (NERI) has estimated an average cost of the negative health effects connected to $\mathrm{NO}_{\mathrm{X}}$ pollution of DKK $85\left(€ 11.4^{2006}\right) / \mathrm{kg} \mathrm{NO}$. This price covers only health effects. The negative effects of eutrophication, for instance, are not covered by this price. Furthermore, the price is dependent on where the emission occurs and on population density. Therefore, uncertainties are greater, for example, for emission reductions at sea.

Another conclusion from the table is that the 7,000 tonne shortfall can also be made up by implementing the two measures with the highest emission reduction potential: SCR on fishing vessels and SCR on heavy vehicles (totalling 7,790 tonne). However, this would not be a costeffective solution; although there would also be a net benefit in implementing these two measures.

Bach et al. (2006)

This report from the National Environmental Research Institute (NERI) analyses (ex ante) the economic consequences of the EU Thematic Strategy on Air Pollution for Denmark, a strategy that will lead to new national emission ceilings for the period 2010 to 2020.

It is interesting that NERI's forecast of the Danish $\mathrm{NO}_{\mathrm{X}}$ emission level (117,000 tonne) is considerably higher than IIASA's forecast $(105,000$ tonne). The disparity is primarily due to differences in the energy statistics used (Bach et al. 2006: 8). Bach et al. (2006) also assess that IIASA overestimates the $\mathrm{SO}_{2}$ emission reduction.

Emission ceilings in the new NEC Directive are expected to present a challenge in the case of Denmark, in particular regarding $\mathrm{NO}_{\mathrm{X}}$ and $\mathrm{NH}_{3}$ (ibid: 36). 
According to Bach et al. (2006: 61) changes in fodder technology in the Danish agricultural sector imply lower $\mathrm{NH}_{3}$ emissions than projected previously by IIASA and others.

Regarding $\mathrm{NO}_{\mathrm{X}}$ emissions, the report compares the results from the Danish Environmental Protection Agency $(2006 \mathrm{a}+\mathrm{b})$ (see above) with those from IIASA's analysis. The results from the two analyses differ to some degree - one reason might be the different time horizons applied (Bach et al. 2006: 66), but also that some methodological problems are apparent in the IIASA cost calculations (ibid: 73ff). In general, IIASA assess that it is possible to cut emissions more, and at lower cost than does the Environmental Protection Agency (ibid: 64). Based on the IIASA and the Environmental Protection Agency calculations, Bach et al. (2006: 70) present the following table with potential $\mathrm{NO}_{\mathrm{X}}$ emission reduction measures for attainment of the 2010 and 2020 ceilings.

Table 4.2 An estimation of potential $\mathrm{NO}_{\mathrm{x}}$ measures to reduce the Danish emissions in 2010 and 2020 against a baseline scenario

\begin{tabular}{|c|c|c|c|c|}
\hline & $\begin{array}{r}2006-2010 \text { million } \\
\text { DKK per year }\end{array}$ & $\begin{array}{r}\text { Emission } 2010 \\
\text { Ktonne }\end{array}$ & $\begin{array}{r}2011-2020 \text { million } \\
\text { DKK per year }\end{array}$ & $\begin{array}{r}\text { Emission } 2020 \\
\text { Ktonne }\end{array}$ \\
\hline Danish baseline scenario & & 147.600 & & 116.500 \\
\hline Correction & & -8.000 & & -11.000 \\
\hline \multicolumn{5}{|l|}{ NEC Directive measures } \\
\hline \multicolumn{5}{|l|}{ Low-NO x burner gas and } \\
\hline gas oil (industry) & 3 & -1.400 & & -1.400 \\
\hline \multicolumn{5}{|l|}{ Advanced reburning } \\
\hline$(\mathrm{CPH})$ & 38 & -600 & & -600 \\
\hline \multicolumn{5}{|l|}{ Better distribution gear } \\
\hline$(\mathrm{CPH})$ & 32 & -2.300 & & -2.300 \\
\hline Partial boosting $(\mathrm{CPH})$ & 76 & -900 & & -900 \\
\hline Offshore windmills & 50 & -200 & & -200 \\
\hline SCR on fishing vessels & 7 & -4.800 & & -4.800 \\
\hline SCR on heavy vehicles & 100 & -2.200 & & \\
\hline \multicolumn{5}{|l|}{ Baseline scenario after } \\
\hline NEC measures & & 127.200 & & 95.300 \\
\hline \multicolumn{5}{|l|}{ Thematic strategy measures } \\
\hline \multicolumn{5}{|l|}{ Heavy fuel, coal, bio- } \\
\hline mass, waste (industry) & & & 4 & -1.100 \\
\hline \multicolumn{5}{|l|}{ Gas (households and } \\
\hline commerce) & & & 11 & -500 \\
\hline SCR (industry) & & & 44 & -2.000 \\
\hline \multicolumn{5}{|l|}{ Control of process emis- } \\
\hline sions & & & 33 & -3.200 \\
\hline Tighter Euro norms & & & 145 & -4.600 \\
\hline \multicolumn{5}{|l|}{ Emissions after thematic } \\
\hline strategy & & & & 83.900 \\
\hline Annual extra cost & 306 & & 237 & \\
\hline
\end{tabular}

Source: Bach et al (2006: 70) (based on calculations from Danish EPA and IIASA)

Regarding $\mathrm{SO}_{2}$ emissions, it is possible, based on IIASA's calculations in the RAINS model, to choose between the measures listed in table 4.3. 
Table 4.3 Measures and costs for $\mathrm{SO}_{2}$ reductions in the RAINS model

\begin{tabular}{lllrr}
\hline Fuel & Sector & Measure & $\begin{array}{r}\text { Reduction, } \\
\text { tonne }\end{array}$ & $\begin{array}{r}\text { Cost } \\
\text { (million } \\
\text { DKK per } \\
\text { year) }\end{array}$ \\
\hline Heavy fuel oil & All stationary & S reduction in fuel from 1.0 & & \\
& sources & \% to 0.6 \% & 700 & 3 \\
Heavy fuel oil & Industry & Flue gas desulphurization & 300 & 1 \\
Coal and coke & All sectors & S reduction in fuel to 0.6 \% & 0 & 0 \\
Coal and coke & Industry & Flue gas desulphurization & 100 & 1 \\
Marine fuel & National shipping & S reduction in fuel & 400 & 2 \\
Non fuel & and fishery & Control in addition to CLE & 100 & 1 \\
& Processes & (stages 1-3) & 1.600 & 7 \\
\hline Sum & & & & \\
\hline
\end{tabular}

Source: Bach et al. (2006) (Based on IIASA 2006)

In conclusion, 1,600 tonne $\mathrm{SO}_{2}$ can be removed at a price of DKK $4.4 / \mathrm{kg}$ $\left(€ 0.6^{2006}\right)$. According to IIASA, this will be sufficient to reach the Danish $\mathrm{SO}_{2}$ ceiling for 2020 .

Palmgren et al. (2007)

This analysis assesses (ex ante) SCR catalysts as a tool for complying with the EU limit value for $\mathrm{NO}_{2}$. In a business-as-usual scenario, Denmark will experience problems with attaining the EU $40 \mu \mathrm{g} / \mathrm{m} 3$ limit value in 115 of 138 street locations where measurement takes place.

Different scenarios have been calculated. For example, the analysis shows that scrapping all EURO 1 and older petrol passenger cars and replacing them with EURO 5 cars would cut the number of street locations where the limit is exceeded to 105 . The number of street locations in exceedance of the limit would be reduced further - to 67 - if all diesel vehicles were equipped with SCR catalysts. However, this is not realistic from a technological or economic viewpoint. The combination of scrapping old petrol passenger cars and the introduction of SCR catalysts on all diesel vehicles with particle filters would result in 55 street locations being in exceedance of the limit in 2010 (58 in 2015). Implementation of an environmental zone would lead to further $\mathrm{NO}_{2}$ pollution, because the greater number of particle filters involved in such a measure would result in higher $\mathrm{NO}_{2}$ emissions at the same time as reducing particle pollution (for an update of the report, see Ketzel \& Palmgren 2008). 


\subsection{Finland}

In 2001, the OECD concluded that Finland had made progress in reducing emissions of conventional atmospheric pollutants. $\mathrm{SO}_{\mathrm{X}}$ emissions declined by $81 \%$, and $\mathrm{NO}_{\mathrm{X}}$ emissions stabilized during the period 1980 to 1995 . On the other hand, the OECD further concluded that Finnish progress was less striking than it may have seemed at first sight - e.g. because in the mid 1980s emission levels were very high and thereby relatively easy to cut. Moreover, the OECD pointed to the fact that Finland was facing a tough challenge with regard to the Sofia Declaration goal of $30 \% \mathrm{NO}_{\mathrm{X}}$ reduction ${ }^{3}$ (1980 to 1998), and the goal of $30 \%$ VOC emission reduction (1988 to 1999). Among the factors contributing to the problems in reaching Finnish air emission goals were increasing road traffic and relatively low energy prices (OECD 2001a).

A National Climate Strategy was drawn up in 2001. Potential effects of the planned emission reduction measures were evaluated in 1998 when the EU Emission Ceilings Directive was prepared (Ministry of the Environment 2002: 31).

Goals concerning $\mathrm{SO}_{2}$ emissions have been reached by introducing sectoral reduction targets for sulphur emissions from power stations, pulp mills, sulphuric acid plants and oil refineries, and limitations on permitted sulphur content in coal and oil products (Ministry of the Environment 2002: 11).

Furthermore, Finland has introduced energy and $\mathrm{CO}_{2}$ taxes, and has levied excise duties on transportation fuels (Speck et al. 2006: 99).

With regard to $\mathrm{NO}_{\mathrm{X}}$ emissions, the Finnish Government has issued general instructions for restricting emissions from boilers and gas turbines and, under the Road Traffic Act (1988), limitations on emissions from road transport. Here a requirement was that new petrol-engined vehicles be fitted with 'three-way' catalytic converters (1991) (Ministry of the Environment 2002: 12).

The VOC target has been difficult to reach according to the Ministry of the Environment (2002: 13). The reasons are that emissions from nonroad machinery and equipment have been higher than expected, and that old vehicles have not been replaced as quickly as expected. Strict emission limits have been applied to new vehicles since 1990 and differential taxes have paved the way for 'reformulated' traffic fuels.

Ammonia emissions have declined in Finland during the 1990s partly as a result of measures introduced to curb water pollution (ibid).

Among the proposals in the OECD review are that Finland continue to improve cost-effectiveness in air management through 'combined use of economic instruments, regulations and voluntary agreements and empha-

\footnotetext{
${ }^{3}$ Finland was only obliged to stabilize the $\mathrm{NO}_{\mathrm{x}}$ emission 1987 to 1994 , but further stated that it would reduce emissions by $30 \%$ in the period 1980 to 1998 (see http://www.un.org/esa/agenda21/natlinfo/countr/finland/natur.htm).
} 
sis on integrated pollution prevention and control' (OECD 2001a); and that Finland develops and implements a strategy to lessen the environmental problems from road traffic.

In 2005, the Finnish Ministry of the Environment concluded that harmful emissions and acidification have both declined considerably. However, natural habitats in sensitive areas are still subject to more acid input than they can receive. Furthermore, urban air quality has not improved as much as expected, despite curbs in traffic emissions. Emission of fine particles remains a serious problem (Ministry of the Environment 2005: 2).

In general, only a few systematic ex post evaluations of environmental legislation in Finland have been carried out (Hildén et al. 2002: 10). According to Hiltunen (2004: 23), 'the impacts of economic policy instruments have been assessed in Finland mainly on the basis of theoretical economic models or interviews at companies before the implementation of a certain tax or measure'.

\section{Ministry of the Environment (2002)}

In this report, the Air Pollution Programme is described and some effects are analysed ex ante. It is emphasised that most of the air pollution in Finland has its origin in neighbouring countries, highlighting from a costeffectiveness perspective the importance of international cooperation (Ministry of the Environment 2002: 33).

\section{Hildén et al. (2002)}

This (meta-)evaluation, which focuses on the pulp and paper industry and the chemical industry, evaluates:

- the regulatory instruments in the Water Act, the Air

Pollution Control Act and the Chemicals Act

- electricity taxation

- voluntary environmental management systems

The early phases of Finnish air pollution control were aimed at listing companies with potential air pollution problems, in an attempt thereby to increase knowledge on the issue. Environmental improvements were expected to arise from this increased knowledge (Hildén et al. 2002: 61).

The Finnish Air Pollution Control Act came into force in 1982. The act contained general norms and guidelines for emissions. During the first years, the act was based solely on a notification system, the idea being to increase knowledge on the problem. From this knowledge, environmental improvements were expected to arise. However, it became apparent that further action was required and, in the period 1992 to 1995 , a permit 
mechanism was developed within the act (Hildén et al. 2002: 42, 61). An Environmental Permit Procedure Act came into force in 1992, bringing the various existing permit systems together under one. Later, the Environmental Pollution Act (2000) integrated much of the legislation into one act.

The earlier Air Pollution Control Act contained a list of installations which required a permit. Pulp was among such installations but not paper mills; however, a paper mill could include an installation which was on the list (e.g. a power station). In total there were more than 70 permit decisions for the 43 paper mills when the evaluation in Hildén et al. (2002) was prepared.

Data in this part of the evaluation covers 38 paper mill permits. More than half of these permits included a $\mathrm{NO}_{\mathrm{X}}$ limit value. One third of the permits contained a $\mathrm{SO}_{\mathrm{X}}$ limit value. Approximately one fourth of the permits included technological requirements (primarily concerning 'type of filter for emission control').

With regard to Finnish regulatory instruments, there is a general problem associated with attributing the exact impact to the implementation of a particular instrument, 'because several developments and societal changes have worked in the same direction as the desired main effects' (ibid: 53). However, as regards air pollution control, changes due to the instruments are observable. For example, emission of acidifying substances has declined. A 1993 report from the Finnish Ministry of the Environment showed that 'the bulk of the reduction is due to a change in the basic production process, i.e. sulphite mills were substituted with sulphate mills. In addition, however, end-of-pipe investments have contributed to further reduction' (ibid: 54).

Another interesting finding is that environmental protection investments in the pulp and paper industry have totalled between 7.7 and 18.3 $\%$ of this industry's total fixed investments from 1992 to 1997 (ibid: 57). In 1997, the industry invested 200 million FIM ( $€ 34^{1997}$ million $)^{4}$ in air protection measures.

Hildén et al. (2002: 63) state that prime focus in Finland has been on regulatory instruments, while economic instruments have been assigned a more secondary role. However, evaluating the effects of these measures is not easy: ' $\ldots$ impacts cannot be unambiguously attributed to the instruments' (ibid: 67). The authors were not able to draw any conclusive conclusions with regard to effectiveness; although there was a 'strong indication that the value of the benefits of the regulatory instruments has been greater than their costs in the case of pulp and paper production' (ibid: 68).

The Finnish $\mathrm{CO}_{2}$ tax is of interest in the context of the present analysis as a $\mathrm{CO}_{2}$ tax potentially has an indirect effect on, for example, $\mathrm{SO}_{\mathrm{X}}$ and $\mathrm{NO}_{\mathrm{X}}$ levels. Finland was a forerunner with regard to $\mathrm{CO}_{2}$ taxation, intro-

\footnotetext{
${ }^{4} €$ exchange rate for 1999 .
} 
ducing the first $\mathrm{CO}_{2}$ tax as early as 1990 (Andersen et al., 2001). In 1997, however, the tax was replaced by a combined $\mathrm{CO}_{2} /$ electricity $\operatorname{tax}^{5}$ (see also Vehmas 2005). The prime purpose of this new tax was fiscal, but it was also motivated by a desire not to harm the international competitiveness of Finnish companies. According to Hildén et al. (2002: 71, 112), the industrial carbon-energy tax level is low and the indication is that this tax only brings about marginal environmental effects in the industries concerned. For example, production of the most energy-intensive pulp has continued to grow rapidly. Interviews with some of the companies exposed to the tax reveal that several companies find that energy prices are already very high - with or without the tax - and therefore, according to these companies, all simple solutions to save energy have already been implemented (ibid: 71). In general, care has to be taken in interpreting data from interviews with affected groups. In this case, for example, the groups may have a vested interest when indicating that the tax has no environmental effect, and that a raised tax level would have no environmental effect either.

An Economic Council evaluation cited by Hildén et al. (2002: 72) shows that the Finnish $\mathrm{CO}_{2}$ emission may have been up to $7 \%$ higher in 1998 if the tax had not been introduced. Most of this is due to the tax on transport fuels. A quarter of the effect is due to changed energy consumption in industry. The calculations here, however, are associated with a large degree of uncertainty. An indirect effect of the tax is likely to be that it has inspired industries to commit themselves to voluntary energysaving agreements. In 1999, approx. $75 \%$ of industrial energy consumption was covered by voluntary agreements, with an associated saving potential of $1 \%$ of industrial energy consumption identified. It is concluded in the study that:

'... a $\mathrm{CO}_{2}$ tax would be a cost-efficient instrument to reduce emissions. A tax would also provide the industry with continuous incentives to develop energysaving technology and technology based on renewable energy. The problems of using taxes to address global environmental issues are related to the political problems involved in designing a global, or even international, tax and the problems for small open economies to use taxes unilaterally.'

\section{Hiltunen (2004)}

This meta evaluation describes the (lack of) experience with evaluations of economic environmental policy instruments in Finland. It is however concluded, in line with Hildén et al. (2002) (see above), that:

'... when energy taxes have been increased, the competitiveness of Finnish companies has been considered so important that the tax burden has been directed towards households and the service industry, while attempts have been made to pro-

\footnotetext{
${ }^{5}$ Since this time, the general structure of energy taxation has remained unchanged (Ministry of the Environment 2005: 19).
} 
tect industry's competitiveness with different aid schemes and a lower price for electricity. As a result, the incentives created for industry by energy taxation remain limited, and the economic policy instruments are not effective' (Hiltunen 2004: 28).

A comprehensive comparative study of effects of environmental tax reforms (COMETR) concludes that the Finnish 1997 environmental tax reform 'reduced fuel demand by around $5 \%$ in 2004, and the same amount in 2012 (expected). There are declines in demand for all of the main fuels (gas, electricity and middle distillates) of around 4\% in 2004. The demand for coal and heavy oil is reduced even more, but from a lower base' (Andersen et al 2007b: 394).

\section{Ministry of the Environment (2005)}

This national report on Finnish air pollution describes emission trends and instruments in Finnish air pollution policy. Besides referring to the Economic Council report also cited by Hildén et al. (2002), the price elasticity for energy demand has been calculated in this report. It has been based on consumer behaviour in Finnish households 1966-1985, and is estimated at -0.36 . According to a study carried out by the EU Commission, the price elasticity of the demand for private vehicles is -0.1 (Ministry of the Environment 2005: 20-21).

\subsection{Iceland}

In general, Iceland enjoys cleaner air than more densely populated countries in continental Europe. However, air pollution in the greater Reykjavik area is a problem, primarily due to traffic (Ministry for the Environment in Iceland 2002: 25; OECD 2001b: 72).

In 2001, OECD (2001b) noted that Iceland is party only to a few international agreements on transboundary air pollution, and it is further noted that Iceland has not taken measures to reduce GHG emissions from transport or from the fishing industry. The Icelandic fishing fleet is a contributing factor to explaining why the per capita $\mathrm{NO}_{\mathrm{X}}$ emission of Iceland is considerably higher than the OECD average. VOC per capita was also at a very high level (OECD 2001b: 72, 110). The OECD states that the private sectors' knowledge of new environmental law in Iceland is poor, and that laws are not fully enforced.

In 2001, there were no economic instruments directly aimed at limiting air pollution. There were, however, some environmentally related taxes and subsidies aimed to have an effect on air pollution levels - e.g. the gasoline tax and taxes on ownership motor vehicles. Diesel gas was not taxed - but a higher motor vehicle tax was levied on diesel cars (OECD 2001b: 38, 78-79; Speck et al. 2006: 115). 
According to the OECD, most Icelandic ministries and local authorities pay a great deal of attention to economic considerations, while integration of environmental considerations in sectoral policies is limited. The OECD also notes that Iceland's taxation policy 'has been developed without taking full account of environmental issues, and use of economic instruments for environmental policy is limited' (OECD 2001b: 20). In the Ministry of Finance and Ministry of Industry and Commerce, environmental expertise is limited and in the Ministry for the Environment economic expertise is absent (OECD 2001b: 73). OECD (2001b: 67) has recommended Iceland to:

- review the environmental effects of the tax system

- integrate environmental concerns into fiscal policies

- expand the use of economic instruments for environmental management

It is recognized, however, that the population of Iceland is very small and that administrative capacity is strained (OECD 2001: 108). With regard to air pollution, however, it was stated that:

\footnotetext{
'While growth in $\mathrm{NO}_{\mathrm{X}}$ emissions is a source of concern in many countries, Iceland is among the countries hoping that a technical solution will be found and that it will not have to take difficult preventive measures. The recent decrease in the car registration tax for larger vehicles provides an economic signal that contradicts attempts to reduce car $\mathrm{NO}_{\mathrm{X}}$ emissions. Stronger air pollution abatement measures are needed in the inhabited areas near Reykjavik and aboard fishing vessels, which are by far Iceland's largest emitter of $\mathrm{NO}_{\mathrm{X}}$ (as well as a major source of $\mathrm{CO}_{2}$ )' (OECD 2001b: 110, OECD's italics).
}

In 2002, the Icelandic Ministry for the Environment stated in the new strategy - 'Welfare for the Future' - that:

\footnotetext{
'Economic incentives have been used to a certain extent in Iceland, for instance with the levy of a fee on hazardous waste and a deposit fee on disposable beverage containers. The quota system on fish catches is also an example of an economic incentive. The aim is to introduce more economic instruments in the field of environmental protection and resource utilization in the near future' (Ministry for the Environment in Iceland 2002: 13).
}

In 2006, statistical indicators showed that Iceland was still experiencing a problem with $\mathrm{NO}_{2}$ pollution in the Reykjavik area. Sometimes exceedance of the 24-hour $\mathrm{NO}_{2}$ limit was recorded and 'on calm winter days, a clearly visible layer of polluted air' could be seen 'to blanket the city' (Ministry for the Environment in Iceland 2006: 11). The number of private cars in Iceland continues to rise, and the number of motor vehicles per capita is now among the highest in the world. The number of people using public transportation is diminishing. Public transportation is used only for $5 \%$ of trips. $60 \%$ of trips made in private vehicles are shorter 
than $3 \mathrm{~km}$ - and roughly one third are shorter than $1 \mathrm{~km}$ (ibid: 13). Emissions of ozone and $\mathrm{SO}_{2}$ are within reference limits (ibid: 9-10). No evaluations of Icelandic air pollution policies have been identified.

\subsection{Norway}

In 2001, OECD (2001c: 95-97, 160) concluded that Norway was successful in decoupling $\mathrm{SO}_{2}$ emissions from economic growth, but was experiencing considerable difficulties in fulfilling the goals for $\mathrm{NO}_{\mathrm{X}}$ and VOC. These problems were caused, for example, by a large increase in offshore oil and gas production as well as expansion in the transport sector. Some of the OECD's recommendations were to:

'... continue to extend use of economic instruments for environmental management, on the basis of the conceptual work carried out in the 1990s (e.g. tradeable permits, green taxation); consider mechanisms to achieve better results concerning emissions of $\mathrm{NO}_{\mathrm{X}}$ and VOCs and nutrient discharges ... assess further the economic rationale of exempting some emitters from paying the full rate of the $\mathrm{CO}_{2}$ tax, taking into account the environmental and social implications of these rate differences' (OECD 2001c: 20, OECD's italics)

The OECD further noted that:

' $\ldots$ it has become clear that, despite international commitments to reduce $\mathrm{NO}_{\mathrm{X}}$ emissions, there is considerable debate at the national level on the priority to be given the required investments. Detractors mainly question their costeffectiveness' (OECD 2001c: 160, OECD's italics)

Norway was the only OECD country experiencing increasing levels of VOC emission in the period 1988 to 1999, during which time the Norwegian VOC emission increased by $39 \%$ - primarily due to increased oil and gas production (OECD 2001c: 160).

As early as 1971, Norway introduced an environmental tax on the sulphur in mineral oil. Within the field of air pollution, Norway has introduced an $\mathrm{SO}_{2}$ tax and a $\mathrm{CO}_{2}$ tax, and has implemented range of transport and energy taxes (OECD 2001c: 43, 103; Speck et al. 2006: 169) in addition to command-and-control measures.

Norway is still experiencing problems lowering overall $\mathrm{NO}_{\mathrm{X}}$ emissions. Fulfilment of the goal under the Gothenburg Protocol demands a $20 \%$ emission cut in the (short) period 2005-2010 (Ministry of the Environment 2007: 9, 12). A new $\mathrm{NO}_{\mathrm{X}}$ tax was therefore introduced in January 2007, and the government indicated a tightening of industrial emission limits (ibid: 138). The Norwegian government further emphasised that it is very important for Norway to reach the goals in the Gothenburg Protocol, because Norway was among the pioneers in promoting international agreements regarding air pollution - fulfilment of the goals there- 
fore represents an important international signal for Norway to be able to send (ibid: 139).

Domestic shipping and fishing account for $37 \%$ of Norwegian $\mathrm{NO}_{\mathrm{x}}$ emissions, and it is here where the greatest potential for reduction lies. Costs for emission reductions are expected to be higher for inland industry than the offshore sector (ibid: 139). However, one possibility is to install low-NO $\mathrm{N}_{\mathrm{X}}$ turbines (Dry Low Emission (DLE)) in the offshore sector (Statistisk Sentralbyrå 2008) - a measure also considered in Denmark.

The $\mathrm{NO}_{\mathrm{X}}$ tax introduced in January 2007 amounts to NOK $15 / \mathrm{kg} \mathrm{NO}_{\mathrm{X}}$ $\left(€ 1.9^{2007}\right)$. The tax applies to propulsion engines with a total effect of more than $750 \mathrm{~kW}$, engines/boilers/turbines in energy installations with an effect of more than $10 \mathrm{MW}$, and to flaring. The tax is estimated to cover $55 \%$ of Norwegian $\mathrm{NO}_{\mathrm{X}}$ emissions. Economic compensation has been applied in the case of a small number of industries. A further opportunity is to obtain an exemption from the tax in connection with a voluntary agreement regarding $\mathrm{NO}_{\mathrm{X}}$ reduction negotiated with the authorities (Ministry of the Environment 2007: 139).

A 2008 voluntary agreement between the Norwegian government and 14 sectors means that companies within these sectors can be exempted from the $\mathrm{NO}_{\mathrm{x}}$ tax in the period 2008-2010 if they commit themselves to reduce $\mathrm{NO}_{\mathrm{X}}$ emissions by introducing new technology. Instead of paying the tax, the companies pay to a fund supporting investments in new technology. The largest $\mathrm{NO}_{\mathrm{X}}$ reductions from the new initiative are expected within shipping and the fishing fleet (Ministry of the Environment 2008a). In total, an emission reduction of 31,000 tonne is expected before the end of 2011 (Statistisk Sentralbyrå 2008).

In conclusion, the Norwegian $\mathrm{NO}_{\mathrm{X}}$ tax is considerably lower than the Swedish tax, but the Norwegian tax is targeted towards a larger share of the total emission.

Regarding $\mathrm{NH}_{3}$, Norway experienced a $13 \%$ rise in this emission during the years 1990-2005. The 2005 emission level corresponds to the obligation in the Gothenburg Protocol (23,000 tonne). Emissions from agriculture have been stable. The rise in the emission can be attributed to introduction of more cars with three-way catalysts (Ministry of the Environment 2007: 140).

Regarding $\mathrm{SO}_{2}$, Norway is currently (2007) below the emission limit established in the Gothenburg Protocol (22,000 tonne). But, an expected rise in activity in the manufacturing industry as well as an expected increase in oil consumption may jeopardize Norway's attainment of the $\mathrm{SO}_{2}$ goal. Therefore, according to the Norwegian government, emission conditions in the manufacturing industry will be tightened (ibid: 137).

Norway experienced a $32 \%$ increase in VOC emissions from 1990 to 2001 , but a $41 \%$ decline during the years 2001 to 2005 . The recent reduction is primarily due to the 2001 regulation regarding storage of crude 
oil and offshore loading buoys (ibid: 138). The downward trend continued in 2006 (Statistisk Sentralbyrå 2008).

\section{Norwegian Official Report (1995)}

In this comprehensive analysis of measures in Norway's environmental policy there is a number of interesting discussions. An introduction of tradable $\mathrm{SO}_{2}$ quotas is discussed (ibid: 385 ), and it is assessed that quotas will have a cost-effectiveness similar to the $\mathrm{SO}_{2}$ tax. In addition, quotas do have the advantage, that they are effective in reaching a certain goal. In contrast, due to uncertainties, it can be difficult to assess ex ante, how much pollution reduction a tax will cause. Regarding $\mathrm{NH}_{3}$ it is stated that there are both uncertainties regarding the level of $\mathrm{NH}_{3}$ emissions and the cost of lowering emissions, but it is predicted that Norwegian costs of reducing $\mathrm{NH}_{3}$ are higher than those experienced in other European countries (ibid: 381). Regarding $\mathrm{NO}_{\mathrm{X}}$ it is reported that measures seem to be implemented due to local conditions and not regional or national conditions (ibid: 380 ).

Dragsund et al. (1999)

This evaluation drew (ex ante) attention to the huge potential with regard to reduction of VOC emissions in connection with the offshore industry's floating loading platforms (see above). It was estimated that a 128,000 tonne VOC reduction could be achieved at a price of only NOK $0.3 / \mathrm{kg}$ VOC $\left(€ 0.04^{1999}\right)$ (Dragsund et al. 1999: 9).

Table 4.4. and 4.5. summarize the estimated cost-effectiveness of different VOC reducing measures in the offshore industry and in inland oil and gas consumption. 
Table 4.4 Alternative potential measures and costs regarding NMVOC reduction in the Norwegian offshore sector

\begin{tabular}{|c|c|c|c|c|}
\hline $\begin{array}{l}\text { Alternative measures for } \\
\text { reducing NMVOC (SFT 1997) }\end{array}$ & $\begin{array}{r}\text { Baseline sce- } \\
\text { nario, no new } \\
\text { measures (tonne) }\end{array}$ & $\begin{array}{r}\text { Potential emis- } \\
\text { sion reduction } \\
1999 \text { (tonne) }\end{array}$ & $\begin{array}{r}\text { Costs } \\
\text { (1000 NOK } \\
\text { per year) }\end{array}$ & $\begin{array}{r}\text { Cost-effectiveness } \\
\text { (NOK per kg } \\
\text { NMVOC) }\end{array}$ \\
\hline Offshore oil and gas & 700 & & & \\
\hline $\begin{array}{l}\text { - Recycling compressor } \\
\text { for gas }\end{array}$ & & 220 & 2560 & 12 \\
\hline - Atmospheric flare & & 400 & 8660 & 22 \\
\hline $\begin{array}{l}\text {-Nitrogen as cover gas } \\
\text { and purge gas }\end{array}$ & & 75 & 550 & 7 \\
\hline $\begin{array}{l}\text { Loading of crude oil } \\
\text { offshore. Measures } \\
\text { introduced: }\end{array}$ & 183400 & & & \\
\hline $\begin{array}{l}\text { - on } 20 \text { offshore loading } \\
\text { buoys }\end{array}$ & & 128406 & 38380 & 0,3 \\
\hline $\begin{array}{l}\text { - on } 15 \text { offshore loading } \\
\text { buoys }\end{array}$ & & 96300 & 28780 & 0,3 \\
\hline $\begin{array}{l}\text { Loading of crude oil } \\
\text { offshore south of } 62^{\circ} \mathrm{N} \text {. } \\
\text { Measures introduced: }\end{array}$ & $(142400)$ & & & \\
\hline $\begin{array}{l}\text { - on } 20 \text { offshore loading } \\
\text { buoys }\end{array}$ & & 99700 & 38380 & 0,4 \\
\hline $\begin{array}{l}\text { - on } 15 \text { offshore loading } \\
\text { buoys }\end{array}$ & & 74800 & 28780 & 0,4 \\
\hline
\end{tabular}

Source: Dragsund et al. (1999: 58)

Table 4.5 Alternative potential actions and costs regarding NMVOC reduction in the Norwegian inland oil and gas use

\begin{tabular}{|c|c|c|c|c|}
\hline $\begin{array}{l}\text { Alternative measures for } \\
\text { reducing NMVOC (SFT } \\
\text { 1997) }\end{array}$ & $\begin{array}{l}\text { Baseline sce- } \\
\text { nario, no new } \\
\text { measures (tonne) }\end{array}$ & $\begin{array}{l}\text { Potential emis- } \\
\text { sion reduction } \\
1999 \text { (tonne) }\end{array}$ & $\begin{array}{l}\text { Costs } \\
(1000 \text { NOK } \\
\text { per year })\end{array}$ & $\begin{array}{l}\text { Cost-effectiveness } \\
\text { (NOK per kg } \\
\text { NMVOC) }\end{array}$ \\
\hline \multicolumn{5}{|l|}{ Mainland oil and gas } \\
\hline -Crude oil terminals & 6090 & 3650 & 24270 & 6,6 \\
\hline -Gas terminals & 1780 & 1600 & 9340 & 5,8 \\
\hline -Refineries & 16060 & 7500 & 8590 & 1,1 \\
\hline Total & 23930 & 12750 & 42200 & 3,3 \\
\hline $\begin{array}{l}\text { Reduction of emission } \\
\text { from solvents, industrial } \\
\text { processes }\end{array}$ & 5440 & 3110 & 9090 & 2,9 \\
\hline $\begin{array}{l}\text { Step } 2 \text { on gas stations, } \\
\text { measures against evapo- } \\
\text { ration }\end{array}$ & 2700 & & & \\
\hline $\begin{array}{l}\text {-All gas stations with an } \\
\text { annual flow in excess of } \\
1500 \mathrm{~m}^{3}\end{array}$ & (1593) & 1115 & 14913 & 13,4 \\
\hline $\begin{array}{l}\text {-All gas stations with an } \\
\text { annual yearly flow in } \\
\text { excess of } 2500 \mathrm{~m}^{3}\end{array}$ & (531) & 372 & 2451 & 6,6 \\
\hline $\begin{array}{l}\text { Incentives for using } \\
\text { engine heaters on private } \\
\text { vehicles to avoid cold } \\
\text { starts }\end{array}$ & 13190 & 4490 & 57200 & 12,8 \\
\hline
\end{tabular}




\section{SFT 2006}

This report analyses (ex ante) different $\mathrm{NO}_{\mathrm{X}}$ reducing measures in the offshore sector, mainland industry and domestic shipping. The estimated emission reduction potential is listed in Table 4.6.

Table 4.6.Total technical potential for $\mathrm{NO}_{x}$ reductions (tonne)

\begin{tabular}{rrrrr}
\hline Domestic shipping & Offshore energy & Mainland industry & Newly built ships & Sum \\
\hline 43.000 & 17.000 & 5.500 & 10.000 & 75.500 \\
\hline
\end{tabular}

Source: SFT (2006: 49)

The costs of the different measures are calculated for each sector. A $7 \%$ discount rate is used for the calculations. The Norwegian Ministry of Finance normally recommends a discount rate of $4 \%$ for measures with low systematic risk, and $6 \%$ for measures with high systematic risk. The lower the discount rate, the lower the estimated costs (SFT 2006: 50). Figure 4.4 shows average costs within the offshore sector for different turbine installations.

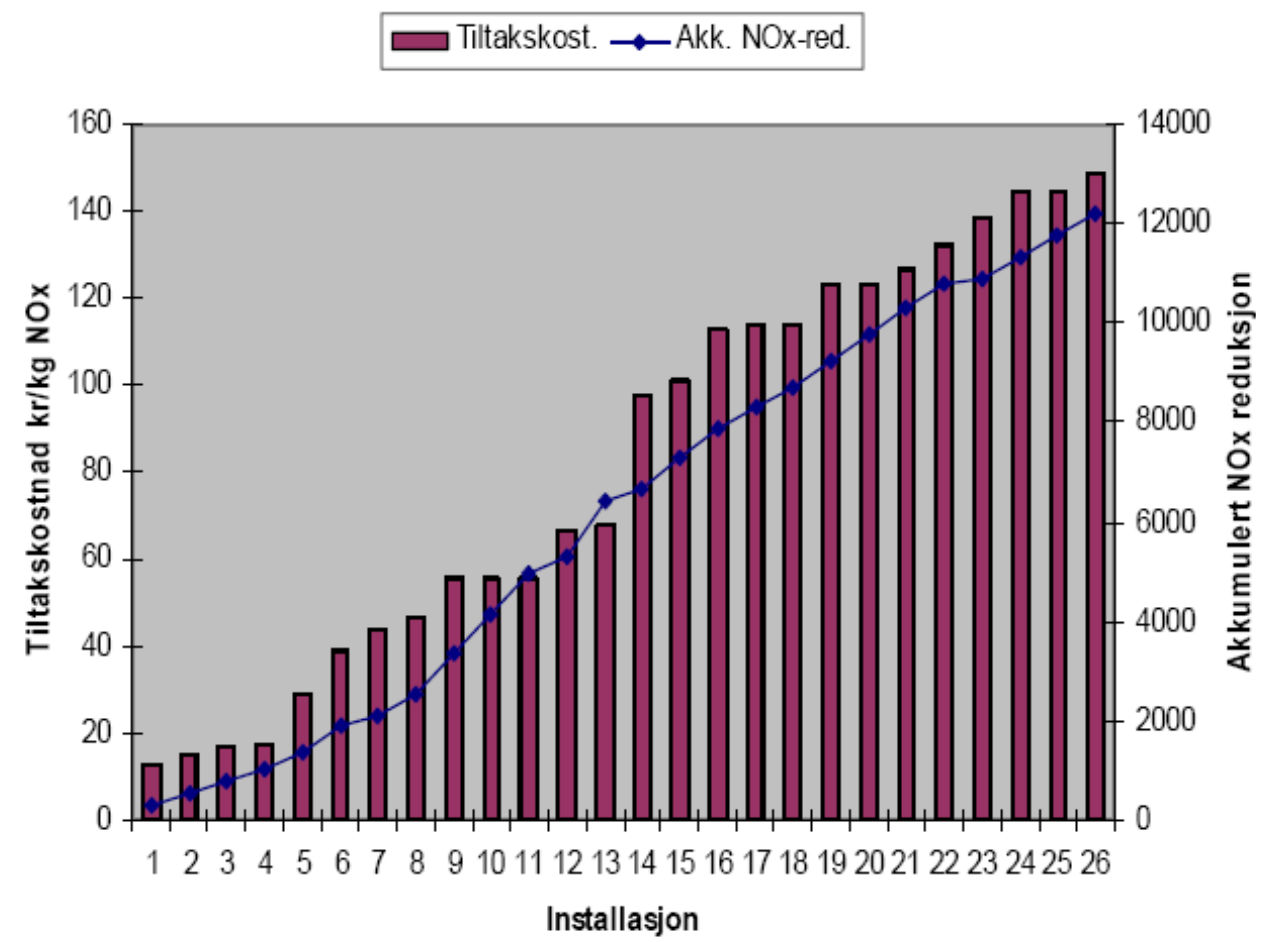

Figure 4.4. Measures and cost (NOK) per $\mathrm{kg} \mathrm{NO}_{X}$, offshore sector

Source: SFT (2006: 52)

*only installations with reduction costs below NOK 150 per $\mathrm{kg} \mathrm{NO}_{x}$ are included

*Y-axis: Cost (NOK) per kg NO . X-axis: Turbine installation number. Z-axis: Accumulated $\mathrm{NO}_{x}$ reduction.

Within mainland industry and shipping, estimated costs per $\mathrm{kg} \mathrm{NO}_{\mathrm{X}}$ reduction are between NOK 6 and 25/kg (€0.75-3.11 $\left.1^{2006}\right)$. The least-cost solution is technical rebuilding of ship engines $(6 \mathrm{NOK}$ per $\mathrm{kg} \mathrm{NO}$ 
$\left.\left(€ 0.75^{2006}\right)\right)$. Catalytic cleaning (SCR) on ships and part of industry has an estimated cost of 9 NOK per $\mathrm{kg}\left(€ 1.12^{2006}\right)$. These two measures alone have an estimated emission reduction potential of 29,000 tonne $\mathrm{NO}_{\mathrm{X}}$ (ibid: 52).

\section{ECON 2007}

The background for this analysis was that the new $\mathrm{NO}_{\mathrm{X}}$ tax introduced in January 2007 only amounted to $15 \mathrm{NOK} / \mathrm{kg}\left(€ 1.87^{2007}\right)$, while estimations showed that fulfilment of the $\mathrm{NO}_{\mathrm{X}}$ goal in the Gothenburg Protocol may demand a tax level of approx. NOK 50-60/kg NO $\left(€ 6.24-7.49^{2007}\right)$ The report analyses (ex ante) the economic effects of a higher tax level within shipping.

In short, a tax level of $50-60 \mathrm{NOK} / \mathrm{kg}\left(€ 6.24-7.49^{2007}\right)$ is expected to have severe negative effects in most of the fishery sector. One problem is that fisheries cannot pass the tax on to the consumer, because market prices within the sector are primarily internationally determined.

For cargo ships, it is possible that the tax may move part of today's freight from ships to trucks, or from larger ships to smaller ships. The economic costs of 1 cargo ship being substituted by 21 trucks once a week has an economic cost of 4.16 million NOK per year to Norwegian society $\left(€ 0.52\right.$ million $\left.^{2007}\right)$.

Cruise ships and the fast ferry (Hurtigruten) service on the Norwegian west coast might experience lower demand for their services if a tax leads to higher fares.

\subsection{Sweden}

According to OECD (2004: 145, 167), Swedish air quality has improved as a result of stringent emission controls. Sweden has been a front-runner with regard to meeting commitments under the Convention on Longrange Transboundary Air Pollution. Considerable progress has been achieved through a range of different measures, including $\mathrm{NO}_{\mathrm{X}}$ charges, fuel quality regulations, promotion of district heating, and environmentally differentiated fairway dues for shipping. $\mathrm{NO}_{\mathrm{X}}, \mathrm{SO}_{\mathrm{X}}$ and $\mathrm{VOC}$ have been reduced considerably since 1996. However, many Swedes still experience health problems due to urban air pollution (particle pollution). The frequency of asthma, allergies and other forms of hypersensitivity has increased considerably since the mid-1990s.

Sweden has a number of excise duties on fossil fuels (Speck et al. 2006: 191) in addition to traditional command-and-control regulation.

Nitrogen and sulphur deposition has fallen considerably since the late 1980s, but ecosystems are still suffering from earlier deposition - critical levels are exceeded in much of southern Sweden (OECD 2004: 165). 
Approximately 17,000 of 95,000 lakes are acidified. Emissions from ships in the Baltic Sea are still growing, but Sweden is participating in international discussions regarding regulation of these ship emissions. It is expected that the marginal costs of limiting ship emissions will be low (ibid: 166).

Differentiated fairway and port dues for ships equipped with emission control devices or ships using low-sulphur diesel have proved very effective. Rebates are given to low polluters while high polluters pay more. Overall, the tax revenue is constant. This policy instrument has led to an estimated $50 \%$ reduction in ship-generated $\mathrm{SO}_{\mathrm{X}}$ emissions (OECD 2004: 166).

Originally, Sweden relied on a command-and-control approach towards $\mathrm{NO}_{\mathrm{X}}$ pollution, but today Sweden can demonstrate a long line of experience with $\mathrm{NO}_{\mathrm{X}}$ taxation. A Swedish tax on $\mathrm{NO}_{\mathrm{X}}$ emissions was proposed in 1989 and implemented with effect from 1992 (Environmental Protection Agency 2003). The tax is levied on boilers, combustion engines and gas turbines with an energy production of more than $25 \mathrm{GWh}$ per year (from 1992-1995 the limit was $50 \mathrm{GWh}$, in 1996 it was 40 GWh, and in $199725 \mathrm{Gwh}$ ). In 2001, approximately 250 plants were embraced by the tax, with approx. 400 production units. However, these plants only represented approx. $5 \%$ of all airborne $\mathrm{NO}_{\mathrm{X}}$ emissions in Sweden (Isaksson 2005: 105; Environmental Protection Agency 2003).

The tax level remained unchanged at $40 \mathrm{SEK} / \mathrm{kg} \mathrm{NO}_{2}\left(€ 4.28^{2008}\right)$ until 2008 , where the tax level was raised to $50 \mathrm{SEK} / \mathrm{kg}\left(€ 5.35^{2008}\right)$. It is expected that the raised tax level will cut emissions by 3,000- 5,000 tonne per year (Ministry of Environment 2008b).

The part of the tax revenue not spent on administration of the scheme is reimbursed to the combustion plants, but not evenly: low emissions per unit of energy produced qualify for a higher share of the reimbursement.

In addition to the tax, plants had to comply with other regulation (permits). Waste incineration and energy production plants had to keep their emissions beneath a $\mathrm{NO}_{\mathrm{X}}$ ceiling (introduced in 1992). Moreover, the conditions for these industries' emissions were further tightened in 1990 (Ministry of Environment and Natural Resources 1993: 37ff).

One purpose of introducing the tax was to make the reduction in emissions quicker than would have been obtained only by introducing emission ceilings (Environmental Protection Agency 2003: 11). NEBEI (2005: 6) credits the Swedish $\mathrm{NO}_{\mathrm{X}}$ tax with being an excellent policy instrument.

A Swedish road tax experiment in Stockholm during the first half of 2006 led to reduced air pollution: $\mathrm{CO}_{2}$ pollution fell by $14 \%, \mathrm{NO}_{\mathrm{X}}$ by 7 $\%$ and particles by $9 \%$. Furthermore, noise pollution fell by 1-2 dbA, traffic safety improved, and there was no negative effect on trade within the area. However, when the experiment ended, traffic levels soon returned to normal (Ministry of the Environment 2007: 49). 
Sulphur regulation in Sweden was also characterized by commandand-control measures, but in 1991 a sulphur tax was introduced (OECD 2007: 123).

\section{Ministry of Environment and Natural Resources 1993}

In this publication, the Swedish $\mathrm{NO}_{\mathrm{X}}$ tax on combustion plants is evaluated. The tax was introduced 1 January 1992.

The evaluation is based primarily on a questionnaire to the $185 \mathrm{com}-$ bustion plants in Sweden. The industry types were: Energy (80), Waste (23), Forestry (49), Metal (4), Chemical (29). The response rate was 88 $\%$. Plants were, for example, asked to identify emissions before and after the introduction of the tax. If they had reduced their emissions, they were further asked to identify how much of the reduction was a direct cause of the new tax (ibid: 38). Emissions fell in 1992 to a level of 13,550 tonnes from a level of 21,000 tonnes (in a 'normal' year). The estimated effect of the tax is $50 \%$ of the reduction (3,725 tonne). Overall, on average, $\mathrm{NO}_{\mathrm{X}}$ emission levels in 1992 fell from 159 to $103 \mathrm{mg}$ per MJ energy.

The plants had taken 77 actions to reduce emissions directly due to the new $\mathrm{NO}_{\mathrm{X}}$ tax, and 35 actions due to the more restrictive conditions. A total of SEK 255 million (ECU 28.0 million $^{1993}$ ) was invested in improved combustion technologies and SEK 430 million (ECU $47.3^{1993}$ ) in cleaning measures, e.g. flue-gas cleaning technologies.

Table 4.7 shows average costs for $\mathrm{NO}_{\mathrm{X}}$ reduction according to industry, and Table 4.8 shows average costs according to fuel type.

Table 4.7 Average costs for $\mathrm{NO}_{\mathrm{x}}$ reduction $\left(\mathrm{SEK} / \mathrm{kg} \mathrm{NO} \mathrm{N}_{\mathrm{x}}\right.$ ) with a depreciation of 5 or 10 years, and $\mathrm{NO}_{x}$ reduction ( $\mathrm{mg} / \mathrm{MJ}$ ), according to industry

\begin{tabular}{|c|c|c|c|c|c|}
\hline & Waste & Energy & Chemical & Metal & Forestry \\
\hline $\begin{array}{l}\text { Emission level before action (average, } \\
\mathrm{mg} / \mathrm{MJ} \text { ) }\end{array}$ & 184 & 161 & 180 & Unknown & 134 \\
\hline Emission level 1992 (after) (average, mg MJ) & 136 & 98 & 88 & 45 & 110 \\
\hline \multicolumn{6}{|l|}{$\begin{array}{l}\text { Improved combustion technologies (SEK/kg } \\
\text { reduced } \mathrm{NO}_{\mathrm{x}} \text { ) }\end{array}$} \\
\hline - 11\%, 5 years & 16 & 24 & 32 & & 19 \\
\hline - 11\%, 10 years & 10 & 15 & 20 & & 13 \\
\hline $\begin{array}{l}\mathrm{NO} \times \text { reduction through Improved combustion } \\
\text { technologies (average } \mathrm{mg} / \mathrm{MJ} \text { ) }\end{array}$ & 41 & 49 & 115 & & 34 \\
\hline \multicolumn{6}{|l|}{ Cleaning measures (SEK/kg reduced $\mathrm{NO}_{\mathrm{x}}$ ) } \\
\hline - $11 \%, 5$ years & 20 & 50 & & & 31 \\
\hline - 11\%, 10 years & 14 & 34 & & & 25 \\
\hline $\begin{array}{l}\mathrm{NO} \times \text { reduction through cleaning measures } \\
\text { (average } \mathrm{mg} / \mathrm{MJ} \text { ) }\end{array}$ & 108 & 150 & & & 35 \\
\hline
\end{tabular}

Source: Ministry of Environment and Natural Resources (1993: 42). 
Table 4.8 Average costs for $\mathrm{NO}_{\mathrm{x}}$ reduction (SEK/kg NO $\mathrm{x}_{\mathrm{x}}$ ) with depreciation 5 or 10 years, and $\mathrm{NO}_{\mathrm{x}}$ reduction $(\mathrm{mg} / \mathrm{MJ})$, by fuel type

\begin{tabular}{|c|c|c|c|c|c|c|c|c|}
\hline & Waste & Biofuels & Bioloil & $\operatorname{Mix}(*)$ & Gas & Coal & Oil & Peat \\
\hline \multicolumn{9}{|l|}{$\begin{array}{l}\text { Improved combustion technologies } \\
\left(\mathrm{SEK} / \mathrm{kg} \text { reduced } \mathrm{NO}_{\mathrm{x}} \text { ) }\right.\end{array}$} \\
\hline - $11 \%, 5$ years & 16 & 11 & 13 & 43 & 32 & 12 & 83 & 7 \\
\hline - $11 \%, 10$ years & 10 & 8 & 8 & 28 & 21 & 8 & 52 & 4 \\
\hline $\begin{array}{l}\mathrm{NO}_{x} \text { reduction through Improved } \\
\text { combustion technologies (average } \\
\mathrm{mg} / \mathrm{MJ} \text { ) }\end{array}$ & 41 & 33 & 8 & 38 & 80 & 57 & 44 & 64 \\
\hline \multicolumn{9}{|l|}{$\begin{array}{l}\text { Cleaning measures (SEK/kg } \\
\text { reduced } \mathrm{NO}_{x} \text { ) }\end{array}$} \\
\hline - $11 \%, 5$ years & 20 & 14 & & 66 & & 69 & & 15 \\
\hline$-11 \%, 10$ years & 14 & 10 & & 50 & & 46 & & 10 \\
\hline $\begin{array}{l}\mathrm{NO}_{x} \text { reduction through cleaning } \\
\text { measures (average } \mathrm{mg} / \mathrm{MJ} \text { ) }\end{array}$ & 108 & 73 & & 18 & & 225 & & 60 \\
\hline
\end{tabular}

Source: Ministry of Environment and Natural Resources (1993: 44).

(*) Mix of coal, biofuels and/or peat

An important conclusion from the two tables is that most of the measures taken to reduce emissions have incurred an average cost below the tax level SEK $40 \mathrm{~kg} \mathrm{NO}$ (ECU 4.40 ${ }^{1993}$ ).

There are some negative environmental side effects connected with some of the measures implemented ${ }^{6}$, e.g. increased emission of $\mathrm{CO}, \mathrm{N}_{2} \mathrm{O}$ and $\mathrm{NH}_{3}$ (ibid: 45-47).

\section{Environmental Protection Agency (1997)}

According to the Environmental Protection Agency (2003: 30), this 1997 evaluation showed that the average $\mathrm{NO}_{\mathrm{X}}$ level fell from approx. $100 \mathrm{mg}$ $\mathrm{NO}_{2} / \mathrm{MJ}$ in 1992 to $65 \mathrm{mg} \mathrm{NO} / \mathrm{MJ}$ in 1995. The energy sector had made the greatest improvements, whilst forestry had made the least progress. An overall conclusion was that the tax is effective.

\section{Sjöfartsverket (1999)}

This report evaluates the differentiated tax on shipping (introduced January 1998). The most polluting vessels were taxed by SEK 5/GT $\left(€ 0.57^{1999}\right)$, while the least polluting vessels were taxed by SEK $2.5 / \mathrm{GT}$ $\left(€ 0.28^{1999}\right)$. The reduced tax level applies to cargo ships and ferries with low sulphur emissions and vessels with reduced $\mathrm{NO}_{\mathrm{X}}$ emissions. $40 \%$ grants were given for investment in $\mathrm{NO}_{\mathrm{X}}$ reducing technology. It is concluded that the differentiated tax has provided an incentive to invest in $\mathrm{NO}_{\mathrm{X}}$ reducing measures, but the shipping companies (in particular the ferry companies) have found the requirements to obtain the tax reductions rather demanding, and a number of companies have thereby been reluc-

\footnotetext{
${ }^{6}$ For an analysis of the negative side effects see Environmental Protection Agency $(1996,2002)$.
} 
tant to undertake investments in expensive technology. The average changes in various pollutants are listed in Table 4.9.

Table 4.9 Average change in emissions from shipping, adjusted for development in activity

\begin{tabular}{lrrrrrr}
\hline$\%$ & $\mathrm{NO}_{\mathbf{x}}$ & $\mathrm{HC}$ & $\mathrm{CO}$ & $\mathrm{CO}_{2}$ & $\mathrm{PM}$ & $\mathrm{S}$ \\
\hline Average change & $-8,3$ & $-4,97$ & 2,07 & 0 & $-2,26$ & $-30,18$ \\
\hline Source: Sjöfartsverket (1999: 19) & & & &
\end{tabular}

It is concluded in the evaluation that the entire effect on $\mathrm{NO}_{\mathrm{X}}$ is due to the differentiated tax, while most of the effect on sulphur emissions can be ascribed to the attention the tax focused on environmental matters (Sjöfartsverket 1999: 19).

The effect of the tax is praised in Milieu (2004a). The tax is collected as a port fee and differentiated according to whether the ships burn low sulphur fuel, have $\mathrm{NO}_{\mathrm{X}}$ burners, etc. The tax is revenue neutral. According to Milieu (2004a: 25), the tax has 'kick-started new technological developments for afterburn of shipping emissions, and tripled the global fleet of ships with this new technology'.

\section{Environmental Protection Agency (2003)}

When this evaluation was published, smaller energy-producing units (25$50 \mathrm{GWh}$ ) had been embraced by the $\mathrm{NO}_{\mathrm{X}}$ tax for six years, and larger energy producing units $(>50 \mathrm{GWh})$ for more than a decade. During the period since the target group was widened in 1997, 474 production units have been subject to the tax.

The evaluation showed that the overall average emission of $\mathrm{NO}_{\mathrm{X}}$ was $0.266 \mathrm{~kg} / \mathrm{MWh}$ in 1997. This level fell to $0.245 \mathrm{~kg} / \mathrm{MWh}$ in 2001 (see Figure 4.5). 


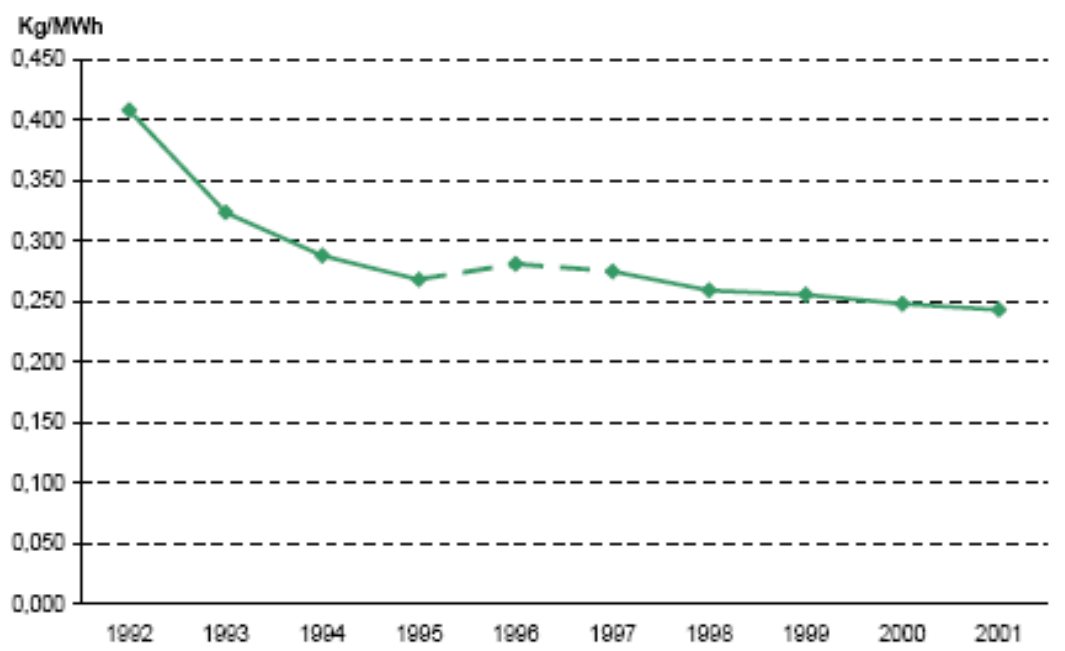

Figure 4.5. Specific emission (kg NOX per MWh) for all boilers 1992-2001.

Source: Environmental Protection Agency (2003: 10)

Note: During the years 1996-1997 the limit for being liable to pay the tax was lowered in two stages from 50 GWh to 25 GWh.

Furthermore, large differences between industries were detected (Figure 4.6). Here, it is important to be aware that several of the industries had already considerably lowered their $\mathrm{NO}_{\mathrm{X}}$ emission per $\mathrm{MWh}$ during the period 1992-1997 (see Figure 4.5).

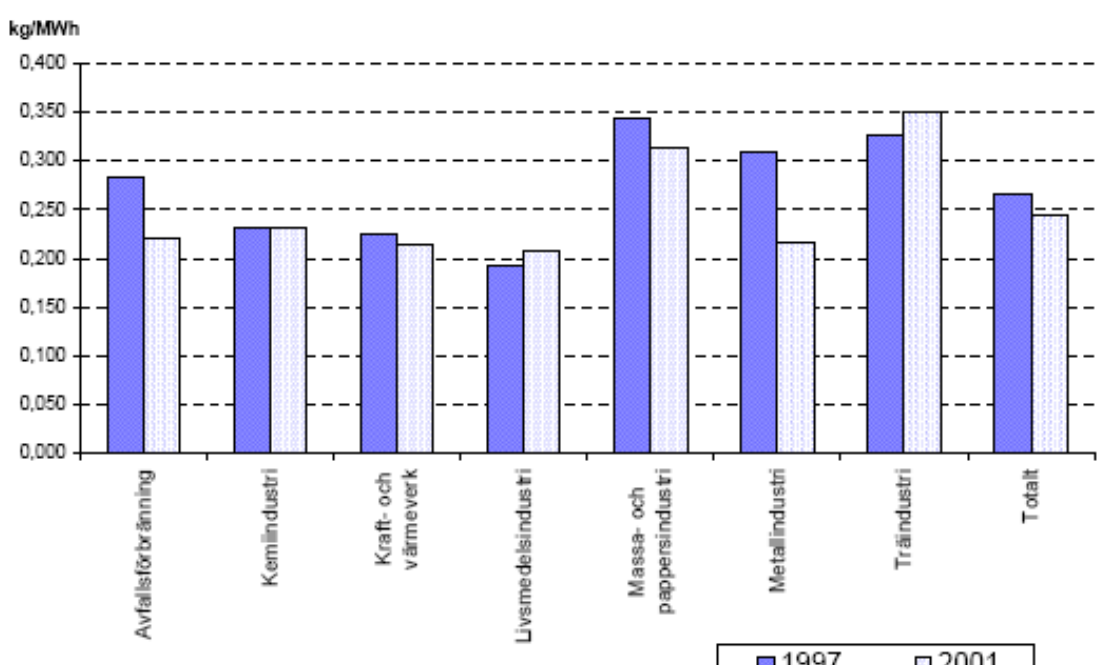

Figure 4.6. $N O_{X}$ emissions (kg) per MWh. 1997 and 2001

Source: Environmental Protection Agency (2003: 39)

Figure 4.6 illustrates the $\mathrm{NO}_{\mathrm{X}}$ emissions $(\mathrm{kg})$ per $\mathrm{MWh}, 1997$ and 2001, for waste incineration, chemicals, heat and power, food, paper and pulp, metal, and wood. The waste and metal industries experienced large $\mathrm{NO}_{\mathrm{X}}$ reductions, while food and forestry actually increased their emission per MWh. 
An interesting question is how much of the emission reduction is due to the tax and how much is due to regulation with ceilings. The authors find this difficult to answer; it is concluded, however, that the emission ceiling establishes a lower limit and that many plants have made additional reductions taking them below this ceiling limit. It is assumed that the tax has had the greatest effect in those sectors where energy production is the main activity, and it is likely that the reductions involved have been achieved more cost-effective than the reductions which can be attributed to the emission ceilings (ibid: 16).

Finally, the evaluation recommended raising the $\mathrm{NO}_{\mathrm{X}}$ tax level, because it had remained unchanged (40 SEK/ $\mathrm{kg}\left(€ 4.54^{1999}\right)$ since 1992; and also because a greater incentive to reduce $\mathrm{NO}_{\mathrm{X}}$ emissions is likely to be required for Sweden to be able to fulfil its international obligations regarding $\mathrm{NO}_{\mathrm{X}}$ reductions.

SOU (2003)

This Swedish Official Government Report mentions that another SOU report $\left(2000\right.$ - 52) recommended that a tradable $\mathrm{NO}_{\mathrm{X}}$ quota system should be considered. SOU (2003) primarily analyses how an effective energy tax system can be constructed.

Regarding the industrial sector, it is recommended that industries continue to be regulated through environmental taxes $\left(\mathrm{CO}_{2} \operatorname{tax}, \mathrm{SO}_{2}\right.$ tax, etc.) and not fiscal taxes (energy tax) (SOU 2003: 137).

\section{Elofsson \& Gren (2004)}

Elofsson \& Gren analyse the cost-effectiveness of different measures regarding reduction in $\mathrm{NO}_{\mathrm{X}}$ emissions impacting the Baltic Sea. The study differs from other analyses in that it calculates the $\mathrm{N}$ distribution across a number of different Baltic reservoirs by means of an input-output analysis (Elofsson \& Gren 2004: 58).

Sweden has three goals for the reduction of N: two subsidiary goals for airborne $\mathrm{N}$ pollution and one for pollution of water.

Table 4.10 summarizes the cost-effectiveness of the Swedish measures targeted at water pollution and air pollution. Emission reduction effects are calculated both for $\mathrm{N}$ reduction at source and $\mathrm{N}$ reduction at the coast. 
Table 4.10 Effects and costs of Swedish nitrogen policies after 1995 (2001 prices)

\begin{tabular}{|c|c|c|c|c|c|c|}
\hline & Measure & $\begin{array}{r}\text { Emission } \\
\text { reduction at } \\
\text { source }(1000 \mathrm{t} \mathrm{N} \\
\text { per year) }\end{array}$ & $\begin{array}{r}\text { Emission } \\
\text { reduction at } \\
\text { the coast } \\
(1000 \mathrm{t} \mathrm{N} \\
\text { per year) }\end{array}$ & $\begin{array}{r}\text { Total cost } \\
\text { (million } \\
\text { SEK per } \\
\text { year) }\end{array}$ & $\begin{array}{r}\text { Average } \\
\text { cost at } \\
\text { source } \\
\text { (SEK per } \\
\text { kg N) }\end{array}$ & $\begin{array}{r}\text { Average } \\
\text { cost at the } \\
\text { coast (SEK } \\
\text { per kg N) }\end{array}$ \\
\hline \multirow[t]{6}{*}{ Water } & $\begin{array}{l}\text { Near-shore } \\
\text { industries }\end{array}$ & 0,771 & 0,771 & 37 & 48 & 48 \\
\hline & $\begin{array}{l}\text { Swedish sew- } \\
\text { age treatment } \\
\text { plants }\end{array}$ & 8,180 & 6,432 & 397 & 48 & $62^{*}$ \\
\hline & $\begin{array}{l}\text { Sewage treat- } \\
\text { ment plants in } \\
\text { the Baltic states }\end{array}$ & 0,084 & 0,060 & 0,76 & 9 & 13 \\
\hline & $\begin{array}{l}\text { Catch crops } \\
\text { and spring } \\
\text { application of } \\
\text { fertilizers }\end{array}$ & 2,300 & 1,860 & 186 & 81 & 100 \\
\hline & $\begin{array}{l}\text { Wetlands with } \\
\text { agricultural } \\
\text { subsidies }\end{array}$ & 0,563 & 0,455 & 20,4 & 36 & 45 \\
\hline & $\begin{array}{l}\text { Wetlands with } \\
\text { LIP subsidies }\end{array}$ & 0,062 & 0,062 & 2,3 & 37 & 37 \\
\hline \multirow[t]{3}{*}{ Air } & $\begin{array}{l}\text { Ammonia } \\
\text { measures in } \\
\text { the agricultural } \\
\text { sector }\end{array}$ & 3,506 & 0,923 & 139 & 40 & 151 \\
\hline & $\begin{array}{l}\text { Catalytic } \\
\text { converters in } \\
\text { private cars }\end{array}$ & 4,100 & 0,720 & 397 & 97 & 552 \\
\hline & Total & 19,567 & 11,283 & 1179,46 & & \\
\hline
\end{tabular}

*Average for plants at the mainland and at the coastline Source: Elofsson \& Gren (2004: 61) (our translation)

Table 4.10 shows that, in general, the greatest environmental effects have been achieved by means of Swedish sewage treatment plants, catch crops/spring application of fertilizer, ammonia reduction measures, and catalytic converters. Building sewage treatment plants in the Baltic states has by far the lowest average cost for $\mathrm{N}$ reduction (SEK 9/kg N $\left.\left(€ 0.99^{2004}\right)\right)$. Regarding air pollution measures, average costs per $\mathrm{kg} \mathrm{N}$ for ammonia measures in the agricultural sector lie within the middle range (SEK 40/kg N (€4.38 $\left.8^{2004}\right)$ ), while average costs for catalytic converters in private cars are very high (SEK 97/ kg N (€10.63 $\left.{ }^{2004}\right)$ ).

One conclusion is that Swedish nitrogen policy has not been cost effective. Measures with high cost and relatively minor environmental effect have been implemented. For instance, implementation of catalytic converters in private cars represents a very expensive way to reduce $\mathrm{N}$ emissions (compared to measures in the marine environment). However, it is important to be aware that catalytic converters do have other positive environmental effects and, therefore, it cannot be concluded that catalytic converters represent an ineffective measure in a wider perspective. It would be interesting to include, in particular, phosphorus reductions in calculation of the cost effectiveness of the various measures. 
Another conclusion is that, in an international perspective, Sweden has access to fewer low-cost $\mathrm{N}$ reducing measures than other countries (Elofsson \& Gren 2004: 63).

\section{Environmental Protection Agency (2004a)}

This report summarizes the (ex post) findings from Environmental Protection Agency (2003) and analyses (ex ante) the possibility of further $\mathrm{NO}_{\mathrm{X}}$ reductions.

One conclusion from the ex ante assessment is that a large $\mathrm{N}$ reducing effect is attainable if the tax level is raised from SEK $40 / \mathrm{kg}$ to SEK $50 / \mathrm{kg}$ $\mathrm{N}\left(€ 4.38\right.$ to $\left.5.48^{2004}\right)$. At SEK 40, $\mathrm{N}$ reduction is expected to total $17 \%$, while this would rise to $38 \%$ with a tax level of SEK 50. On the other hand, increasing the tax level further to SEK $60-70 / \mathrm{kg} \mathrm{N}\left(€ 6.58-7.67^{2004}\right)$ would only have a minor effect, not to mention greater distributional impacts between the companies affected (Environmental Protection Agency (2004a: 52)).

Another conclusion of the report is that the tax should not be extended to cover installations with energy production below $25 \mathrm{GWh}$ per year. Costs associated with measurement and administration are expected to be too high in these companies in relation to the emission reduction potential.

Finally, it is assessed whether the tax should be extended to cover combustion in industrial processes (e.g. this would bring the forestry industry, cement industry, refineries, etc. under the remit of the tax). An extension would cover 19,500 tonnes of $\mathrm{N}$ emission, and, at a tax level of SEK $40\left(€ 4.38^{2004}\right)$, a (conservative) reduction of 1,000 tonnes $\mathrm{N}$ is expected. However, uncertainties exist with regard to economic consequences for the various industries affected; specific recommendation is made not to tax the cement industry, because in recent years this industry has already implemented a number of $\mathrm{N}$ reducing measures, indicating that the potential for further $\mathrm{N}$ reductions in this industry is limited. A recommendation is moreover made to raise the tax level to SEK 50 per kg $\mathrm{N}\left(€ 5.48^{2004}\right)$.

\section{Environmental Protection Agency (2004b)}

This report presents proposals for (continued) green tax reform. Among the proposals are that green taxes should be index regulated. The nominal level of e.g. the $\mathrm{NO}_{\mathrm{X}}$ tax and the $\mathrm{SO}_{2}$ tax has not changed since the introduction of these taxes. Therefore, their environmental effect has been eroded over time.

According to the report, there are 180,000 aging wood-fired boilers in Sweden without an accumulation tank. These cause a considerable amount of VOC pollution. The costs of installing an accumulation tank 
for them all would amount to between SEK 5 and SEK $15 / \mathrm{kg}$ reduced $\operatorname{VOC}\left(€ 0.55-1.64^{2004}\right)$ (ibid: 43$)$.

\section{Isaksson (2005)}

This article analyses abatement costs in response to the Swedish $\mathrm{NO}_{\mathrm{X}}$ tax. Data for the period 1992-1996 on 162 abatement measures implemented in 114 combustion plants are analysed. Therefore, the analysis covers the period before the target group was widened to embrace smaller plants (in 1997). Data is based on a 1996 questionnaire.

Isaksson (2005: 103) first presents an interesting discussion of 'winwin' situations and opportunities characterized as 'low-hanging fruit'. Porter and van der Linde argued (1995) that the cost of compliance with environmental regulation is often offset by innovations in the product and/or the production process. Isaksson sums up the three conditions for win-win-situations as the:

- existence of systematic and unrealized inefficiencies in firms

- capacity of outcome-based environmental regulations to induce a realization of cost-saving opportunities

- cost-saving opportunities being large enough to outweigh any costs associated with regulatory compliance

In the same way, the term 'low-hanging fruit' illustrates the fact that a firm subject to new environmental regulation and in the process of finding the least costly way to comply with the new regulation is likely to find some other improvements that can be carried out at zero cost, or even at a profit (ibid: 104).

According to Isaksson (2005) there is not much empirical evidence to support this, but experience with the Swedish $\mathrm{NO}_{\mathrm{X}}$ tax might add to our knowledge on this topic.

Large plants in Sweden have reduced their emissions by approximately $35 \%$ in the period 1992-1996. The cost of administering the charge has been very low; approx. SEK 1.5 million $\left(€ 0.16^{2005}\right)$ per year $(0.2-0.3 \%$ of total revenue).

According to a 1996 questionnaire response, $47 \%$ of the measures undertaken in plants would not have been implemented without the introduction of the tax. Quantitative reasons are reported as the principal reason for $22 \%$ of the measures, and other reasons for $31 \%$. A number of the results are presented in Table 4.11. 
Table 4.11 Mean annual abatement $\operatorname{cost}^{\mathrm{a}}$ per plant in million SEK/year (1990 prices) and mean reduction in emission rate 1992-96 for analyzed sample by sector and year

\begin{tabular}{|c|c|c|c|c|c|c|c|c|}
\hline \multirow[t]{2}{*}{ Sector } & \multicolumn{7}{|c|}{ Year } & \multirow{2}{*}{$\begin{array}{r}\text { Mean } \\
\text { reduction } \\
\text { in emis- } \\
\text { sion rate } \\
1992-96\end{array}$} \\
\hline & 1990 & 1991 & 1992 & 1993 & 1994 & 1995 & 1996 & \\
\hline Energy & 0.149 & 0.394 & 0.602 & 0.640 & 1.452 & 1.359 & 1.682 & $35 \%$ \\
\hline Pulp and paper & 0 & 0.008 & 0.128 & 0.230 & 0.244 & 0.298 & 0.396 & $25 \%$ \\
\hline Chemical and food & 0 & 0.131 & 0.080 & 0.103 & 0.125 & 0.138 & 0.166 & $31 \%$ \\
\hline Waste combustion & 0.357 & 0.933 & 0.537 & 0.609 & 1.030 & 0.997 & 1.241 & $43 \%$ \\
\hline All sectors & 0.120 & 0.345 & 0.379 & 0.427 & 0.842 & 0.794 & 0.985 & $32 \%$ \\
\hline No. of obs. & 54 & 57 & 100 & 109 & 103 & 102 & 95 & \\
\hline
\end{tabular}

a) Cumulative annual abatement cost, starting from zero cost at Jan 1, 1990 and assuming the expected life-time of fixed investments to be 10 years

Source: Isaksson (2005: 108)

One very striking finding is that for about $30 \%$ of the measures implemented, emission reductions have been obtained at zero cost or even at a profit (ibid: 108). However, only one of these investments brought savings large enough to outweigh the costs, and is therefore the only true win-win measure in Porter and van der Linde terms. However, 'lowhanging fruit' do indeed exist.

Isaksson (2005), moreover, estimates marginal abatement cost functions for the plants. The variable descriptions and statistics are presented in the tables below.

Table 4.12 Variable descriptions

\begin{tabular}{|c|c|c|}
\hline Variable & Description & Unit \\
\hline $\mathrm{C}$ & Total abatement cost & $\mathrm{SEK} / \mathrm{yr}$ \\
\hline MC & Marginal abatement cost & $\mathrm{SEK} / \mathrm{kg}$ \\
\hline z & Dummy for reduced emissions since 1990 & Dummy $(0,1)$ \\
\hline q & Production of useful energy (output) & GWh/yr \\
\hline e & Emission rate (emissions per unit of energy produced) & $\mathrm{Kg} / \mathrm{GWh}$ \\
\hline r & (\% change in emission rate since 1990)/100 & $\%$ \\
\hline $\mathrm{e}^{\mathrm{o}}$ & $\begin{array}{l}\text { Initial emission rate (in year } 1990 \text { or } 1992 \text { for plants that started } \\
\text { monitoring in 1992) }\end{array}$ & $\mathrm{Kg} / \mathrm{GWh}$ \\
\hline it & $\begin{array}{l}\text { Time trend, year of the latest abatement investment, it }=0, \ldots .6 \text { for } \\
\text { years } 1990, \ldots ., 1996\end{array}$ & By year \\
\hline it90,..., it96 & $\begin{array}{l}\text { Dummies for the year of the latest abatement investment, e.g. } \\
\text { It } 90=1 \text { if last abatement investment was implemented in 1990, else } \\
\text { It } 90=0\end{array}$ & Dummy $(0,1)$ \\
\hline Envfuel & $\begin{array}{l}\text { Dummy for type of main fuel used. Envfuel=1 if main fuel used is } \\
\text { biofuel and/or gas, else envfuel=0 }\end{array}$ & Dummy $(0,1)$ \\
\hline Age & Plant age & Years \\
\hline Sector1 & Sector dummies, sector1=1 if Energy sector & Dummy $(0,1)$ \\
\hline Sector2 & Sector2=1 if Pulp and Paper sector & \\
\hline Sector3 & Sector $3=1$ if Chemical and Food sector & \\
\hline Standard & $\begin{array}{l}\text { Emission standard rate (plant subject to no emission standard has } \\
\text { standard }=x^{\circ}\end{array}$ & $\mathrm{Kg} / \mathrm{GWh}$ \\
\hline
\end{tabular}


Table 4.13 Variable statistics

\begin{tabular}{|c|c|c|c|c|c|c|c|c|}
\hline \multirow[t]{2}{*}{ Variable } & \multicolumn{2}{|c|}{$\begin{array}{c}\text { All sectors }(n=107, \\
\text { obs }=531\end{array}$} & \multicolumn{2}{|c|}{ Energy $(n=55$, obs $=280)$} & \multicolumn{2}{|c|}{$\begin{array}{l}\text { Pulp and Paper } \\
(n=28, \text { obs }=130)\end{array}$} & \multicolumn{2}{|c|}{$\begin{array}{l}\text { Chemical and Food } \\
(n=24, \text { obs }=121)\end{array}$} \\
\hline & Mean & Std & Mean & Std & Mean & Std & Mean & Std \\
\hline C & 637,511 & $2,092,062$ & $1,042,506$ & $2,803,245$ & 243,455 & 408,998 & 123,698 & 251,569 \\
\hline MC & 20.0 & 56.8 & 27.7 & 74.7 & 13.7 & 25.8 & 8.99 & 16.3 \\
\hline z & 0.79 & 0.40 & 0.86 & 0.34 & 0.65 & 0.48 & 0.79 & 0.41 \\
\hline$q$ & 234.1 & 254.6 & 274.8 & 317.7 & 251.0 & 173.0 & 121.5 & 50.3 \\
\hline e & 346.3 & 160.4 & 366.6 & 183.2 & 356.1 & 100.0 & 288.9 & 143.8 \\
\hline$r$ & 0.23 & 0.21 & 0.28 & 0.22 & 0.15 & 0.16 & 0.20 & 0.19 \\
\hline$e^{o}$ & 483.5 & 260.5 & 557.5 & 309.4 & 425.9 & 125.5 & 374.0 & 178.1 \\
\hline it & 2.86 & 1.64 & 2.71 & 1.70 & 2.97 & 1.53 & 3.12 & 1.58 \\
\hline it90 & 0.06 & 0.23 & 0.11 & 0.31 & 0 & 0 & 0 & 0 \\
\hline it91 & 0.16 & 0.37 & 0.15 & 0.36 & 0.17 & 0.38 & 0.17 & 0.37 \\
\hline it92 & 0.25 & 0.43 & 0.22 & 0.42 & 0.30 & 0.46 & 0.27 & 0.45 \\
\hline it93 & 0.18 & 0.38 & 0.16 & 0.37 & 0.22 & 0.41 & 0.17 & 0.37 \\
\hline it94 & 0.18 & 0.38 & 0.21 & 0.41 & 0.11 & 0.31 & 0.17 & 0.37 \\
\hline it95 & 1.10 & 0.30 & 0.07 & 0.26 & 0.12 & 0.33 & 0.14 & 0.35 \\
\hline It96 & 0.08 & 0.27 & 0.07 & 0.26 & 0.08 & 0.28 & 0.09 & 0.29 \\
\hline Envfuel & 0.56 & 0.50 & 0.37 & 0.48 & 0.75 & 0.43 & 0.79 & 0.41 \\
\hline Age & 17.0 & 9.70 & 14.1 & 8.92 & 19.5 & 10.4 & 21.1 & 8.45 \\
\hline Sector1 & 352.1 & 270.2 & 357.1 & 334.9 & 375.5 & 159.4 & 315.3 & 179.8 \\
\hline Sector2 & 0.53 & 0.50 & - & - & - & - & - & - \\
\hline Sector3 & 0.24 & 0.43 & - & - & - & - & - & - \\
\hline Standard & 0.23 & 0.42 & - & - & - & - & - & - \\
\hline
\end{tabular}

Source: Isaksson (2005: 111)

For instance, the tables show that the mean marginal abatement costs have been SEK $27.7 / \mathrm{kg}\left(€ 2.98^{2005}\right)$ in the energy sector, SEK $13.7 / \mathrm{kg}$ $\left(€ 1.48^{2005}\right)$ in the pulp and paper sector, and SEK $8.99 / \mathrm{kg}\left(€ 0.97^{2005}\right)$ in the chemical and food sectors. As mentioned, the tax level is SEK 40/kg $\left(€ 4.31^{2005}\right)$. Therefore, there is still reduction potential in pulp and paper as well as the chemical and food sectors.

Initial emission rate seems to have no significant effect on marginal abatement costs (ibid: 115). Scale effects are significant only for the energy sector. Marginal abatement costs fall by about SEK $0.4 / \mathrm{kg}$ $\left(€ 0.04^{2005}\right)$ when energy increases by $10 \mathrm{GW} /$ year. For each additional year of age, marginal abatement costs increase by SEK $3 / \mathrm{kg}\left(€ 0.32^{2005}\right)$ in the energy sector. Surprisingly, for all sectors, plants with low, and thereby strict, emission standards have marginal abatement costs below average (ibid: 116). The energy sector has been most active with regards abatement in the period analysed. Finally, Isaksson (2005: see note 8) points to the fact that some measures in order to reduce $\mathrm{NO}_{\mathrm{X}}$ may imply increased emissions of other pollutants, such as $\mathrm{CO}, \mathrm{VOC}$, and $\mathrm{N}_{2} \mathrm{O}$.

\section{Environmental Protection Agency (2005)}

This report further develops the proposals in Environmental Protection Agency (2004a). With the aim of making a cost-effective $\mathrm{NO}_{\mathrm{x}}$ policy it is proposed: 
- to widen the scope of the tax to embrace industrial processes with exception of lime, cement, wood pellets, glass ovens and ovens for production of light clinker.

- with regard to reimbursement, that the taxed industries comprise one group and the combustion plants another.

- to raise the tax to SEK $50 / \mathrm{kg} \mathrm{NO}_{\mathrm{X}}\left(€ 5.39^{2005}\right)$.

The welfare economic reasons for extending the tax are many (ibid: 17), but to mention just two:

- cost-effectiveness

- negative health effects of $1 \mathrm{~kg}$ Swedish $\mathrm{NO}_{\mathrm{X}}$ amount to at least 62 SEK $\left(€ 6.68^{2005}\right)$

Environmental Protection Agency and the Swedish Energy Agency (2006)

In this review of economic instruments within environmental policy in Sweden, a 1997 evaluation of the $\mathrm{SO}_{2}$ tax is described. The $\mathrm{SO}_{2}$ tax level is SEK 30/kg $\left(€ 3.24^{2006}\right)$. Fuels used within production of lime, stone, cement and boilers in the forestry industry are exempted from the tax. The 1997 evaluation showed that the tax contributed with $30 \%$ of the total $\mathrm{SO}_{2}$ reduction in the period 1989 to 1995 . One effect has been that the sulphur content in heating oil has diminished. Furthermore, industries have made energy use more effective, refineries have lowered the sulphur content in oil, a small switch between heavy and light heating fuels is further observable, and the tax has had a substitution effect from oil towards other fuel types (ibid: 102).

Regarding the $\mathrm{NO}_{\mathrm{X}}$ tax it is concluded, based on earlier evaluations, that the tax is a cost-effective supplement to the traditional commandand-control regulation. The tax has led to a faster and cheaper emission reduction than what would have been achieved with command-andcontrol policy instruments alone. Emission per unit energy has declined by approx. $40 \%$ since the introduction of the tax, but the tax is still only targeted at a relatively small part of the overall Swedish $\mathrm{NO}_{\mathrm{X}}$ emission (ibid: 131).

Regarding ammonia, it is concluded that the prospects of reaching the ammonia goal in 2010 are good (ibid: 68).

It is further concluded in the report that the fall in oil consumption during the 1990s and 2000s (e.g. due to the $\mathrm{CO}_{2}$ tax) has also led to reduced VOC, $\mathrm{SO}_{2}$ and $\mathrm{NO}_{\mathrm{X}}$ emissions (ibid: 140). 


\subsection{Cost-effective goal achievement?}

Overall, it can be concluded that the Nordic countries have experienced significant results in combating the four pollutants embraced by the Gothenburg Protocol, achieving to a large degree a decoupling of these emissions from economic growth. During this decoupling phase, traditional command-and-control measures have over the last two decades been supplemented by 'new' economic instruments. On the other hand, the literature review documents a lack of Nordic ex post evaluation regarding the four air pollutants. As a result, there is a lack of detailed knowledge regarding causes of emission reduction and a lack of knowledge on whether goals within Nordic air pollution policy have been reached cost-effectively. A number of ex ante analyses exist, but as, for instance, the comparison of the IIASA forecast and the NERI forecast show (see Bach et al. (2006) above), estimations in ex ante analyses can differ considerably due to differences in the assumptions on which they are based.

Admittedly, it can be difficult to single out causes of changes in emission levels. Environmental problems are often very complex (Mickwitz 2003). Additionally, for example $\mathrm{NO}_{\mathrm{x}}$ emissions may be the target of a number of different policy instruments. Furthermore, policy instruments targeted towards other pollutants, such as $\mathrm{CO}_{2}$, may have unintended side effects on $\mathrm{NO}_{\mathrm{X}}$ emissions. According to Isaksson (2005) certain $\mathrm{NO}_{\mathrm{X}}$ reducing measures may lead to greater emission of other air pollutants. Needless to say, however, the complexity involved in carrying out reliable ex post evaluation should not prevent those countries that have implemented policy instruments targeted at air pollution from performing this kind of evaluation.

It is beyond the scope of the present project to undertake a comprehensive disentanglement of emission reductions in relation to the relative contributions of various policy instruments, but the literature review can be seen as a first step in this direction. The review reveals what we know - and thereby what we do not know - about the effects of the air pollution policy instruments implemented.

In Denmark, there are not many ex post elements in the analyses performed to date. Some interesting ex ante calculations on how to close the Danish ' $\mathrm{NO}_{\mathrm{X}}$ gap' have been made. The benefits are expected to outweigh the costs - NERI has recently published a conservative estimate of the health benefit of reducing $\mathrm{NO}_{\mathrm{X}}$ pollution of DKK $52\left(€ 7^{2006}\right) / \mathrm{kg} \mathrm{NO}$. When implemented in 2010, it will be interesting to follow the effects of the new Danish $\mathrm{NO}_{\mathrm{X}}$ tax (DKK $5 / \mathrm{kg}\left(€ 0.7^{2008}\right)$ on stationary sources onshore and offshore.

With regard to Danish $\mathrm{SO}_{2}$ emissions it was forecasted in 1999 that the $1996 \mathrm{SO}_{2}$ tax (DKK 10-20/kg sulphur (€1.3-2.7 2008$)$ ) would reduce $\mathrm{SO}_{2}$ emissions by 34,000 tonnes per year by 2005 . This calculation was based 
on introduction of cleaner technology and a lowering of the sulphur content in the various fuels. Furthermore, a substitution effect involving switches to fuels with low sulphur content was expected. It is apparent that the $\mathrm{SO}_{2}$ tax has had an effect - the Danish $\mathrm{SO}_{2}$ emission intensity is the lowest among OECD countries and emissions declined rapidly in the late 1990s when the tax was introduced. But we still do not know the more precise effect of the tax, due to lack of ex post evaluation.

Similar to the Danish experience, there are very few ex post elements in Finnish air pollution evaluation. Hildén et al.'s (2002) analysis of the paper/pulp and the chemical industry contains an ex post element, but impacts cannot be unambiguously attributed to the various instruments, making it impossible to conclude anything with regard to costeffectiveness. The same is true for Iceland, where no evaluation of air pollution policies has been identified.

Norway has introduced a range of different measures, on which ex post evaluation has not been performed. Norway reduced VOC emissions by $41 \%$ within only four years (2001-2005) - primarily by introducing regulation regarding storage of crude oil and regulation regarding the offshore industry's floating loading platforms. An ex ante assessment (Dragsund 1999) of the offshore loading buoy regulation indicated that a 128,000 tonne of VOC reduction could be reached at a price of only NOK $0.3 / \mathrm{kg}$ VOC $\left(€ 0.04^{1999}\right)$. Indication that the regulation had a comprehensive effect is strong, but ex post the cost-effectiveness of the regulation is not known due to lack of evaluation.

Similarly to Denmark, Norway has experienced problems in reaching the $\mathrm{NO}_{\mathrm{X}}$ ceiling. Recently (2007), a NO tax $\left(\mathrm{NOK} 15 / \mathrm{kg}\left(€ 1.9^{2007}\right)\right)$ has been implemented - a tax targeted towards $55 \%$ of the total Norwegian $\mathrm{NO}_{\mathrm{X}}$ emission. Before its introduction, an ex ante assessment indicated a $\mathrm{NO}_{\mathrm{X}}$ reduction potential of 75,000 tonne within mainland industry, the offshore sector and domestic shipping. Some of the most promising measures are, as in Denmark, catalytic cleaning (SCR) on ships and part of industry, with an estimated cost of NOK $9 / \mathrm{kg} \mathrm{NO}\left(€ 1.12^{2006}\right)$, and technical rebuilding of ship engines - at NOK 6/kg NO . $\left(€ 0.75^{2006}\right)$. The Norwegian $\mathrm{NO}_{\mathrm{X}}$ tax is combined with another policy instrument - voluntary agreements. It is possible for the industries affected to enter into a voluntary agreement of emission reduction with the authorities, thereby avoiding the tax. It will be very interesting to learn more about the effects of this flexible instrument during coming years. Moreover, there may be lessons to learn for other parties to the Gothenburg Protocol as well.

The most comprehensive Nordic ex post evaluation of the four pollutants is contained in the analyses of the Swedish $\mathrm{NO}_{\mathrm{X}}$ tax on combustion plants. The tax took effect from 1992 and remained at a level of SEK 40 $\mathrm{kg} / \mathrm{NO}_{\mathrm{X}} 1992-2007\left(€ 4.33^{2007}\right)$. The 250 plants targeted by the original tax only represented approximately $5 \%$ of the total Swedish $\mathrm{NO}_{\mathrm{x}}$ emission. In 2008, the tax level was raised to SEK $50\left(€ 5.35^{2008}\right)$ and today the 
tax covers a greater number of plants. An interview-based ex post evaluation (Ministry of Environment and Natural Resources 1993), performed one year after the tax was implemented, showed very good progress in lowering the $\mathrm{NO}_{\mathrm{X}}$ intensity of production. Improved combustion technologies had been implemented at the plants affected by the tax at a price of SEK $10-32 / \mathrm{kg} \mathrm{NO}_{\mathrm{X}}\left(€ 1.10-3.52^{1993}\right)$, and various cleaning measures at a price of SEK $14-50 / \mathrm{kg} \mathrm{NO}_{\mathrm{X}}\left(€ 1.54-5.50^{1993}\right)$. The good results were confirmed in the Isaksson (2005) evaluation of the period 1992-1996, which furthermore estimated that costs of administering the tax have been very low $(0.2-0.3 \%$ of total revenue). Another interesting finding was that $30 \%$ of the measures implemented at the plants obtained emission reductions at zero cost or even at a profit. Furthermore, the study showed that mean marginal abatement costs were SEK $27.7 / \mathrm{kg} \mathrm{NO}_{\mathrm{X}}\left(€ 2.98^{2005}\right)$ in the energy sector, SEK $13.7 / \mathrm{kg} \mathrm{NO} \mathrm{N}_{\mathrm{X}}\left(€ 1.48^{2005}\right)$ in the pulp and paper sector, and SEK $8.99 / \mathrm{kg} \mathrm{NO}_{\mathrm{X}}\left(€ 0.97^{2005}\right)$ in the chemical and food sector. The tax level was SEK 40/kg NO $\left(€ 4.31^{2005}\right.$ ) (from 2008 SEK 50), indicating that there was room for further reduction within these sectors. Some final interesting observations in Isaksson (2005) were that; i) the initial emission rate does not seem to have had a significant effect on marginal abatement costs, ii) scale effects were only significant in the energy sector, iii) for each additional year of age of the plant, marginal abatement costs in the energy plants increased by SEK $3 / \mathrm{kg} \mathrm{NO}_{\mathrm{X}}$ $\left(€ 0.32^{2005}\right)$, iv) plants (in all sectors) with strict emission standards have marginal abatement costs below average. The overall emission of $\mathrm{NO}_{\mathrm{X}}$ per MWh has continued to fall during the 1990s and 2000s. An Environmental Protection Agency (2003) evaluation states that the taxes have most likely been more cost-effective than emission ceilings. An Environmental Protection Agency and Swedish Energy Agency (2006) analysis stated that the tax has led to faster and cheaper emission reductions than would have been achieved with command-and-control regulation alone. Emission per unit energy has declined by $40 \%$ since the introduction of the tax.

Finally, it can be added that the Swedish $\mathrm{SO}_{2} \operatorname{tax}\left(\mathrm{SEK} 30 / \mathrm{kg} \mathrm{SO}_{2}\right)$ has contributed with $30 \%$ of the total $\mathrm{SO}_{2}$ reduction in the period 1989-96 (ibid); and a 1998 tax on shipping (collected as a port fee and differentiated according to how 'clean' the ship emissions are) (Sjöfartverket 1999) has reduced $\mathrm{NO}_{\mathrm{X}}$ emissions within shipping by $8.3 \%$ and also had a great impact on the $\mathrm{SO}_{2}$ emission.

In conclusion, there is some evidence that green taxes (on $\mathrm{SO}_{2}, \mathrm{NO}_{\mathrm{X}}$, and $\mathrm{CO}_{2}$ ) have had a comprehensive impact in the Nordic countries, but not much is known about the impact of other policy instruments. This is regrettable - in particular, because many important lessons for other parties to the Gothenburg Protocol could be expected to arise from this knowledge. Therefore, more Nordic ex post analyses of these policy instruments should be welcomed. Furthermore, more documentation might 
also make it possible to compare the cost-effectiveness of these instruments with, for example, experiences from the Dutch $\mathrm{NO}_{\mathrm{X}}$ trading scheme and the US $\mathrm{SO}_{2}$ and $\mathrm{NO}_{\mathrm{X}}$ trading schemes, which are credited by NEBEI (2005: 6) as excellent policy instruments. 



\section{What next?}

\subsection{Reduction targets - percentages or fixed limit values}

As referred to in section 4, the initial phase of air pollution protocols in the 1980s adopted flat-rate numerical reduction obligations which were criticized for their lack of cost-effectiveness. The current phase of the Gothenburg Protocol and the NEC Directive is based, in principle, on the critical load concept and the RAINS model, which have translated the detrimental effects into national emissions ceilings in terms of least-cost optimization (see also section 5.6 below).

According to the official definition 'critical load' means a quantitative estimate of an exposure to one or more pollutants below which significant harmful effects on specified sensitive elements of the environment do not occur, according to present knowledge.

Adjustments and political bargaining imply that the emission reductions based on critical loads were not implemented as fully in the Gothenburg Protocol as would have been the case based purely on the scientific recommendations. It has been estimated that the current Gothenburg emission ceilings close the gap between the reference emission levels projected and critical loads by $30 \%$ for $\mathrm{NO}_{\mathrm{X}}, \mathrm{VOC}$ and $\mathrm{NH}_{3}$, and by approx. $10 \%$ for $\mathrm{SO}_{2}$ (see Ishii, 2001). The limited nature of these closures applies in particular to non-EU15 countries; for EU-15 gaps have been closed by approx. $50 \%$ for $\mathrm{SO}_{2}$ and VOC, but $25 \%$ for $\mathrm{NO}_{\mathrm{X}}$. Even for EU-15 the difference between the reductions that would have followed from purely science-based target setting and those determined by the protocol is notable. One reason for the limited reductions in relation to critical loads is the relatively significant reductions that were projected as a result of business-as-usual and ongoing transformations. These in most cases were several orders of magnitudes larger that the reductions agreed under the protocol and were not always realized. However, a desire to close the gaps further has led to negotiations on revision of the protocol and the new NEC Directive for the enlarged EU-27.

As part of the EU's CAFE (Clean Air for Europe) process a new conceptual method has been developed which has exchanged the critical loads approach for a more straightforward cost-benefit assessment (CBA). Whereas the critical loads approach was both ecosystem and health-related, the new cost-benefit assessment attributes human health impacts a far greater role. The CBA approach factors in the benefits in monetary terms, and presumably will allow decision-makers to improve the economic efficiency of air pollution control. The question remains as to the implications of differences in target levels between the two ap- 
proaches. Current benefit estimates seem to suggest that reductions that surpass the critical load targets would be cost-effective; but much depends on the methodological assumptions in the CBA, notably regarding the value of life-years saved as a result of reduced mortality.

\subsection{A more flexible protocol?}

While from an international politics perspective national emissions ceiling can be a useful approach for allocating emission reductions among sovereign states party to the protocol, there are various qualifications and concerns that deserve careful consideration. The debate resembles the issues that have surfaced over target setting under the Kyoto Protocol.

The present approach of the Gothenburg Protocol based on emission ceilings already offers considerable flexibility and discretion for countries to identify least-cost reductions, as there are no specific requirements to undertake reductions in areas either where exposure peaks or where critical loads are exceeded. Shipping emissions from small vessels in the North Sea count on equal terms with urban sources with high population densities. The EU has, however, agreed specific requirements for exposure ceilings for urban areas with regard to $\mathrm{PM}_{2.5}$ to ensure that not only abatement but also the ultimate benefits will materialize. These requirements reduce flexibility for EU member states.

The main option for introducing additional flexibility in the future seems to be introduction of tradeable quotas for certain pollutants, such as $\mathrm{NO}_{\mathrm{X}}$, while retaining national emissions ceilings. Certain countries, e.g. the Netherlands, have already established a system of emissions trading at the national level for $\mathrm{NO}_{\mathrm{X}}$. A less ambitious approach would be to allow national trading systems to be linked so that credits could be traded between certain countries.

Not all pollutants are equally relevant for trading. For $\mathrm{SO}_{2}$, abatement has advanced considerably and, in any case, abatement costs for $\mathrm{SO}_{2}$ reduction are usually modest. For $\mathrm{SO}_{2}$ as well as primary $\mathrm{PM}_{2.5}$ the external costs that arise from the emissions are despite dispersion primarily identified within $50 \times 50 \mathrm{~km}$ from the source, with the exception of sulphates $\left(\mathrm{SO}_{4}\right)$ which are relevant at the regional level. This implies that trading would displace not only the costs but also most of the benefits, making trading less attractive. For $\mathrm{NO}_{\mathrm{X}}$, transport and dispersion patterns are at a regional level, implying that it is less decisive which source that undertakes abatement, at least within a distance of 5-800 km. For urban areas with high reduction requirements benefit displacement due to trading might result in the need to take less cost-effective measures too, so that more careful modelling is required to assess the appropriateness of $\mathrm{NO}_{\mathrm{x}}$-trading (see also Klaassen et al. 1994; Førsund \& Nævdal 1998; UNECE 1998, for a discussion of $\mathrm{SO}_{2}$ emission trading). 


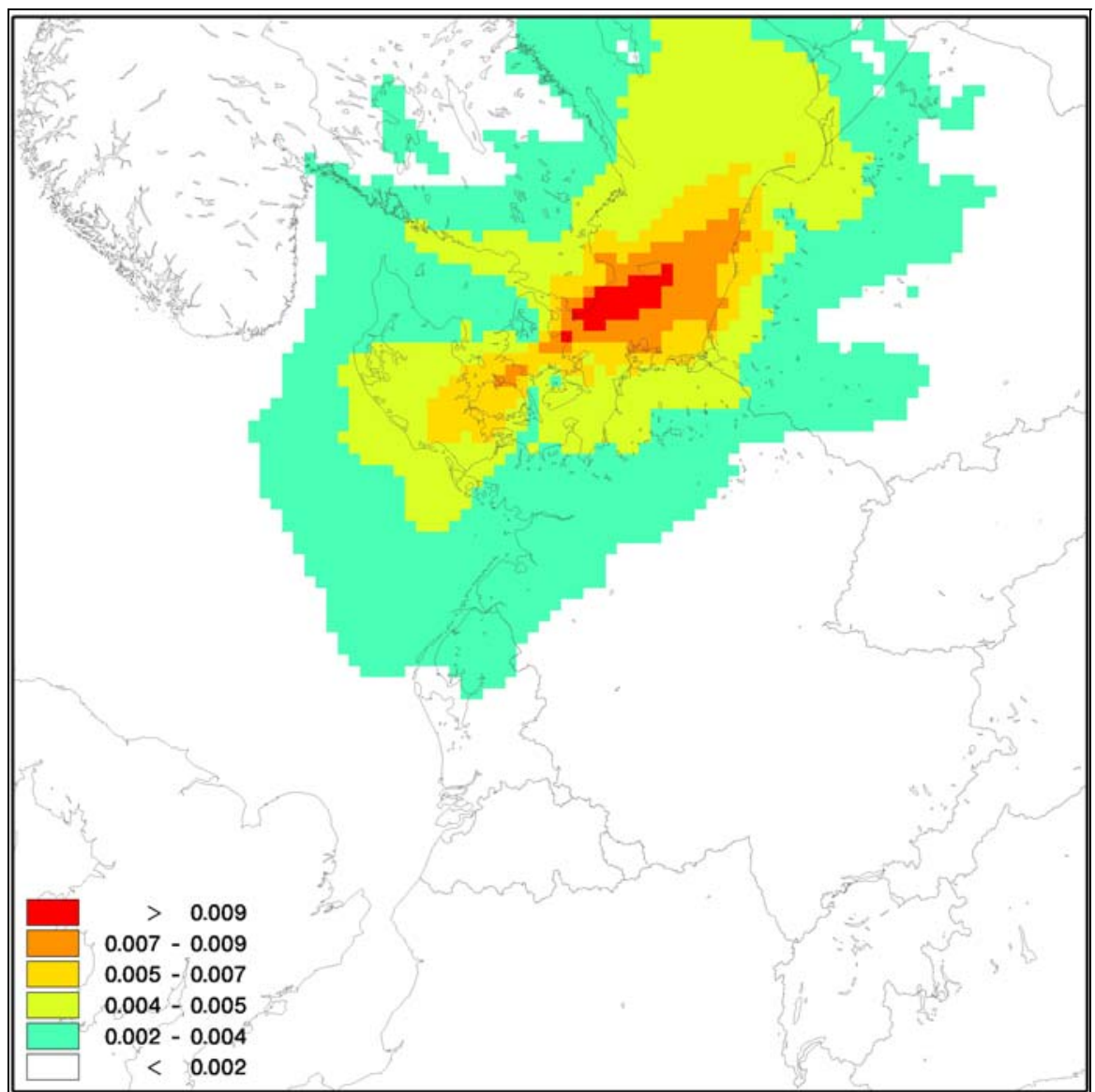

Figure 5.1. Changes in annual delta-concentrations of nitrate particles from NOX emissions of Copenhagen power plant

Source: Andersen et. al. (2008).

A system within the Nordic region allowing for trading e.g. of $\mathrm{NO}_{\mathrm{X}}$ among large sources could be a viable instrument to allow more flexibility. If the allowances are grandfathered they would remain compatible with national regulatory systems, but a more ambitious system based on auctioning is also an option as long as it allows for an opt-out from the $\mathrm{NO}_{\mathrm{X}}$ taxation for the relevant (large) sources. Revenue from auctioning would be required to compensate the loss of tax revenue. The emissions ceilings for 2020 will require additional efforts and the reductions will need to be able to take place in a period characterized by considerable change within the energy supply system. 


\subsection{Validity and reliability of the applied modelling frameworks (RAINS-GAINS)}

\subsubsection{Introduction}

The RAINS model system, like its successor GAINS, consists of modules relevant for processing air pollutant emissions, source-receptor relationships, concentrations/depositions and effects. The model is applied as the standard tool in emission reduction and limit value negotiations in Europe, such as those for the Gothenburg Protocol, the NEC Directive and the Thematic Strategy on Air Pollution.

The RAINS-GAINS model system passed through a review process in 2004 and in 2007. IIASA has subsequently taken many of the recommendations into account in connection with negotiation of the Thematic Strategy on Air Pollution (see e.g. the GAINS Review, 2004 and 2007). In the current report a more scientific viewpoint in relation to the models is taken due to their importance as decision-support tools.

\subsubsection{The basic RAINS-GAINS methodology}

Based on the chosen emission scenarios, air pollutant concentration and deposition values are calculated from a series of source-receptor relationships which provide links between emission reductions in one country and the corresponding changes in concentration and deposition in grid cells across the rest of Europe. These source-receptor relationships form the basis of a subsequent optimization procedure, which is performed to obtain the optimal emission reduction in each country based on predefined cost-benefit assumptions.

\subsubsection{Source-receptor relationships}

For ozone and particulate matter in particular there is a clear non-linear relationship between emissions and concentrations due to the atmospheric chemistry. The correct procedure for assessing and optimizing emission reduction scenarios is therefore to apply a state-of-the-art 3-D Eulerian atmospheric chemistry-transport model, such as e.g. the EMEP model. This however involves numerous model runs, which would be difficult to realize within the typical time span of a protocol negotiation with current computer resources. Instead simplified mathematical functions are applied to describe the source-receptor relationships in RAINS-GAINS for this procedure.

The source-receptor relationships applied in RAINS-GAINS are obtained from calculations in the EMEP model. The procedure is to perform a large number of predefined EMEP model runs in which the emissions are reduced by $15 \%$ in one country for one pollutant $\left(\mathrm{NO}_{\mathrm{X}}, \mathrm{SO}_{2}, \mathrm{NH}_{3}\right.$, 
VOC) at a time. This provides simplified mathematical descriptions (source-receptor relationships) for each chemical component of the linkage between the reduction in emissions in one country and the corresponding concentration changes in every grid cell in Europe. If the influence of a source on a receptor is in fact non-linear, the results of the country-specific scenarios are not additive.

\subsubsection{Linearity versus non-linearity in RAINS}

IIASA has traditionally applied linear source-receptor relationships for $\mathrm{SO}_{2}$. At a later stage, non-linear relationships for $\mathrm{O}_{3}$ between individual countries and grid cells covering Europe for predefined emission reduction scenarios have been implemented; however, these relationships only apply for the country-specific emission reductions they were developed from. For $\mathrm{PM}_{2.5}$ linear relationships have been assumed up until 2004 (Amann et al., 2004). In 2005 the relationships for $\mathrm{PM}_{2.5}$ have been expanded to distinguish between summer and winter situations in order to account for the different chemical regimes $\left(\mathrm{NH}_{3}\right.$ or $\mathrm{NO}_{\mathrm{X}}$ limited; Amann et al., 2005); however the relationships are basically still piecewise linear. The contributions from $\mathrm{NO}_{\mathrm{X}}, \mathrm{NH}_{3}$ and VOC emissions to the concentration of secondary inorganic particles in the individual grid cells are strongly non-linear due to the chemical processes in the atmosphere. This is clearly documented in various reduction scenario calculations performed by IIASA for Germany, the Netherlands, Italy and the United Kingdom. (see e.g. Amann et al., 2004). Some work has been done in this direction, e.g. a sensitivity study performed in Tarrasón et al. (2003), exmines the effects of reducing the emissions from one or more species simultaneously or individually for a single country. This work is not applicable for assessing the impacts of linearity assumptions from a full emission reduction scenario, including all countries. A more relevant study was performed by Bartnicki (2000), where the the nonlinear effects in the source-receptor matrices computed with the EMEP Eulerian model were examined. Here, some figures for the deviation from the linearity assumption were found based on emission reductions in Germany and impacts in other European countries. Only absolute deviations between the non-linear models results and the linear assumptions were given in this report, however, the relative deviations, which are normally much larger were not provided.

It is stated in Amann et al., (2004) that "it remains to be determined how relevant that detected non-linear model responses will be for the practical policy assessment (i.e., for the magnitude of emission changes that will be taken into closer consideration) ansd what bias would be introduced into the calculation by a simplified representation of this phenomenon". The impact of the linear assumption still remains to be determined. 
Due to the complicated processes involved in the formation of $\mathrm{PM}_{2.5}$, it is not possible to quantify the effects from applying the simplified mathematical description of the non-linear source-receptor relationships without carrying out a number of calculations with a state-of-the-art atmospheric chemistry-transport model. Neither is it possible to evaluate whether they will give rise to an over- or underestimation of the $\mathrm{PM}_{2.5}$ concentration.

\subsubsection{Validation of RAINS-GAINS}

The results from the RAINS-GAINS model system - in particular for PM in the Nordic countries - have yet to be put through a thorough scientific validation and published. The results from selected emission reduction scenarios should be compared extensively with corresponding results from a state-of-the-art atmospheric chemistry-transport model (e.g. the EMEP model).

\section{Particulate matter}

In general $\mathrm{PM}_{2.5}$ is divided into primary and secondary particles, where the latter can be divided into organic and inorganic particles. The primary particles typically originate from point sources, dust and sea salt. The secondary organic particles typically originate from manmade sources (traffic, industry, households, etc) and vegetation. The secondary inorganic particles are formed from the emissions of $\mathrm{NO}_{\mathrm{X}}, \mathrm{SO}_{2}$ and $\mathrm{NH}_{3}$. The formation mechanisms for the secondary inorganic particles are, however, also strongly dependent on the emissions of VOC through the chemical processes in the atmosphere.

Neither the secondary organic particles nor the natural aerosols are included in the calculations with the EMEP model. This means that the concentration of $\mathrm{PM}_{2.5}$ is consistently underestimated by a factor of approx. two (van Loon et al., 2004). However, this is currently also the case for all other atmospheric transport-chemistry models in Europe. The consistent underestimation is a problem when assessing concentrations of particulate matter with respect to limit values.

Concentrations in the urban background

For $\mathrm{PM}_{2.5}$ the calculations performed by IIASA focus on concentrations in the urban background. However the EMEP model is a long-range atmospheric chemistry-transport model describing background concentrations at the regional scale with a horizontal resolution of $50 \mathrm{~km} \times 50 \mathrm{~km}$. IIASA has applied simple functions developed within the City-Delta project (Cuvelier et al., 2007). With these functions a redistribution of the coarse resolution EMEP model results to finer resolution is carried out. This method is applicable for a first rough estimate; however, it does not provide accurate results for different cities and different urban areas. 
Boundary conditions

As a basis for emission reductions, calculations with the EMEP model have been carried out with constant boundary conditions for ozone. IIASA has recently increased the background ozone concentration due to projected global emissions; however the boundary condition values remain constant. The model results with constant value boundary conditions should be replaced by results from e.g. a hemispheric/global atmospheric chemistry-transport model.

Applied meteorology

Up until now IIASA have only applied meteorological data for a single year. The data for one year do not necessarily represent a climatic mean for Europe or Scandinavia. In order to obtain results that are robust compared to the variability in external parameters (here the meteorology) mean values from at least 5 years of calculations should form the basis of the scenarios. In the GAINS review from 2007 (Agren et al., 2007), the use of several meteorological years is stated as a model change after the thematic strategy, however, it is also stated that the implementation is still underway.

Documentation

The IIASA documentation regarding the procedures and methods applied in RAINS-GAINS seems in general incomplete. It is therefore very difficult to reproduce the results obtained from RAINS-GAINS calculations scientifically.

\subsubsection{Conclusions and recommendations}

The optimization of source-receptor relations with effects and costbenefit constraints is a highly resource-demanding process, which at present is not realizable with current state-of-the-art atmospheric chemistrytransport models within the time frame of e.g. protocol negotiations. This is one of the specific reasons why the RAINS-GAINS model system has been developed. Results from scenarios calculated with RAINS, however, can be very uncertain since the behaviour of non-linear relationships arising from atmospheric chemistry is strongly simplified.

Based on the reports and calculations published by IIASA, it is currently not possible scientifically to quantify uncertainties or systematic errors in the scenario results obtained. To give quantitative estimates of what the different assumptions in RAINS-GAINS addressed in the above implies for the Nordic countries, it is necessary to recalculate some typical scenarios with a state-of-the-art atmospheric chemistry-transport model. 


\subsection{Which pollutants to address?}

\subsubsection{Introduction}

Regulation of emissions must include pollutants important with regard to impact on the environment and on human health. The present Gothenburg Protocol includes $\mathrm{NO}_{\mathrm{X}}, \mathrm{SO}_{2}$, VOCs and $\mathrm{NH}_{3}$, which are related to ozone formation, deposition of $\mathrm{N}$ - and S-compounds and formation of secondary particles. Primary particles should be included in the new protocol, which are important, especially in relation to human health. However, the new protocol will probably only partly cover secondary organic particles, since the formation processes are not well understood and natural emissions, e.g. from vegetation, play an important role.

\subsubsection{Background}

Human exposure to particulate matter (PM) gives rise to the major adverse health effects in relation to air pollution. The relationship between the health effects and the chemical and physical properties of the particles is not well understood, and until now only simple relationships between $\mathrm{PM}_{10} / \mathrm{PM}_{2.5}$ concentration and death rates, frequency of hospital admissions, etc. have been used for assessment of the negative impacts of particle pollution. It has not however been possible to establish a causal relationship between PM-related health effects and one single PM component. This is in spite of intensive research over the last decade or so. Nevertheless there is strong evidence to conclude that fine particles usually measured as $\mathrm{PM}_{2.5}$ in health effects studies - are more hazardous than larger ones. This does not imply that the coarse fraction of $\mathrm{PM}_{10}$ is innocuous.

PM in urban air consists of contributions from many different sources. The important contributions to particles in urban streets are exhaust particles from traffic, non-exhaust particles from traffic (road surface, tyres, brakes, winter sanding/salting, etc), primary particles from other sources, secondary inorganic particles (from $\mathrm{NO}_{\mathrm{X}}, \mathrm{SO}_{2}$ and $\mathrm{NH}_{3}$ ), secondary organic particles, natural particles from soil, as well as sea and vegetation and particles of unknown origin. Emissions from sources, transport and fate of exhaust particles, secondary inorganic particles and primary particles are all relatively well understood and can be modelled by existing models (local models and EMEP-related regional models). The main problem with non-exhaust particles is quantification of the source strength and this can be handled by the existing local models. 


\section{$\mathrm{PM}_{2.5}$ street}

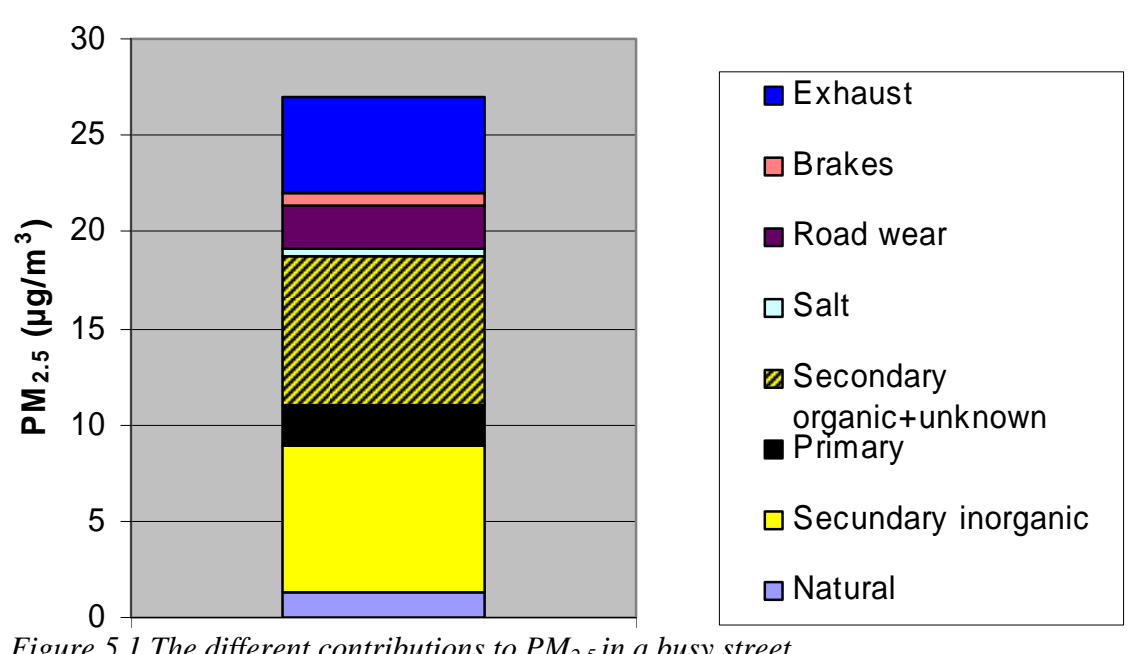

Figure 5.1 The different contributions to $P M_{2.5}$ in a busy street

Secondary organic particles and the unknown fraction of particles contribute significantly (by up to more than $30 \%$ ) to the mass of $\mathrm{PM}_{10}$ $/ \mathrm{PM}_{2.5}$, but the major part of $\mathrm{PM}_{10} / \mathrm{PM}_{2.5 \text { eller }}$ secondary organic particles is a large-scale phenomenon, and contributes significantly to PM pollution, especially in the Nordic urban air. It is therefore important to identify these PM components in order to prioritize the measures for reduction of PM pollution and to create better data for investigation of the relationship to health effects. These particles are not included in most of the assessments carried out because the emissions are very uncertain, the processes are not well understood and the air pollutions models are not able to handle them well.

Ongoing experimental activities and modelling in the Nordic countries cover local as well as regional scales in order to distinguish between the local/urban/national contribution as well as the regional contribution to the PM pollution, especially the organic components. Such studies are important for understanding the atmospheric processes and, in turn, for identification of the individual components and the emissions to be included in assessment of the efficiency of possible measures for reduction of PM and ozone pollution.

\subsubsection{Recommendations for the new protocol}

The new protocol must cover primary particles and precursors to secondary organic particles, including anthropogenic as well as natural emissions of organic gases. Better understanding of the role of natural emissions, e.g. from vegetation, is necessary in order to asses the need for emissions of anthropogenic pollutants. This is probably also the case for ozone formation. 


\subsection{Climate gases}

The present Gothenburg Protocol includes the main conventional air pollutants and does not include the climate gases. However, numerous studies and practical examples have shown that it is important to have a strong coupling between measures taken to reduce the emissions of traditional air pollutants and the climate gases.

Many emission sources are responsible both for emission of traditional air pollutants and of climate gases. Fossil fuels remain one of the most important sources of energy in Europe and combustion of fossil fuels leads to emissions of both $\mathrm{NO}_{\mathrm{x}}, \mathrm{PM}, \mathrm{SO}_{2}$ and $\mathrm{CO}_{2}$. Another example is the use of diesel and petrol for transportation. This activity leads also to emissions of large quantities of $\mathrm{NO}_{\mathrm{x}}, \mathrm{PM}$ and $\mathrm{CO}_{2}$. For example, Danish emissions of $\mathrm{NO}_{\mathrm{X}}, \mathrm{SO}_{2}, \mathrm{PM}_{2.5}$ and $\mathrm{CO}_{2}$ are shown in Figure 1. More than half of the Danish emission of $\mathrm{NO}_{\mathrm{X}}$ comes from the same sources as those that produce emissions of $\mathrm{CO}_{2}$.

Measures taken to reduce one air pollutant may lead to increases in another air pollutant. Wood-burning stoves have been mentioned as a way of reducing emissions of $\mathrm{CO}_{2}$ from domestic space heating. However, recent experiments in Denmark and other countries have shown that increased use of wood stoves results in an increase in local $\mathrm{PM}_{2.5}$ air pollution and thereby leads to increased negative effects on health. $\mathrm{CO}_{2}$ emissions may also be reduced by use of diesel passenger cars instead of petrol passenger cars due to the fact that diesel engines traditionally are more energy efficient than petrol engines. However, with current technology diesel cars lead to significantly higher emissions of directly emitted $\mathrm{NO}_{2}$ than petrol cars. Increased use of diesel passenger cars is one of the reasons why Denmark did not comply with air quality criteria for $\mathrm{NO}_{2}$ in Copenhagen in 2006. Measures taken to reduce the $\mathrm{NH}_{3}$ emission from agriculture can also lead to increased emission of climate gases. Examples of this are injection of manure into the soil, which leads to increases in the emission of $\mathrm{N}_{2} \mathrm{O}$, and covered storage facilities lead to increases in the emission of $\mathrm{CH}_{4}$.

It is not only on the emissions where there is a strong coupling between the traditional air pollutants and the climate gases. Emissions of $\mathrm{NO}_{\mathrm{X}}, \mathrm{SO}_{2}$ and $\mathrm{NH}_{3}$ lead to production of secondary inorganic particles in the atmosphere. Primary particles and secondary inorganic particles account for a large fraction of the atmospheric particulate load. Particles have a strong impact on the radiative balance and emissions of the traditional air pollutants will therefore directly influence climate change.

In order to estimate the economic impact of coupling measures taken to reduce impact of emission of traditional air pollutants and climate gases, the International Institute for Applied System Analysis (IIASA) expanded the RAINS model to include climate gases. The results from use of this new model, called the GAINS model, shows that for the EU 
the cost of implementation of the thematic strategy for reduction of the traditional air pollutants will be reduced from $€ 7$ billion to $€ 2$ billion if the EU policy aiming at a $20 \%$ reduction in $\mathrm{CO}_{2}$ emissions has been implemented (CIAM, 2007).

The strong technical, environmental and economic link between traditional air pollutants and climate gases highlights the importance of coupling policies for reductions of these. It is therefore important that these aspects are taken with into consideration in revision of the Gothenburg Protocol.

Further details on the synergies between air pollution and climate gas policies can be found in the review of the Gothenburg Protocol (CIAM, 2007).

\subsection{A cost-effective solution for Europe}

In preparing the 1999 Gothenburg Protocol, cost-effectiveness analysis was carried out which helped identify least-cost solutions, but the analysis fell short of comparing costs with monetized benefits (Amann and Lutz, 2000:50). Under the cost-effectiveness approach the extent of emission reductions is driven by targets for environmental quality, whereas under a cost-benefit approach the appropriate stringency of emission controls is determined by the balance between emission control costs and monetized environmental benefits. The Gothenburg Protocol nevertheless represented an ambitious attempt to establish a multi-pollutant framework addressing a range of conventional pollutants in a coordinated approach. Evidently, and in the absence of a cost-benefit framework, this necessitated finding a formula for addressing the various pollutants and their somewhat different impacts jointly. The RAINS model combined environmental quality targets for ozone and for acidification, referring to separate thresholds for vegetation and health impacts, and on this basis optimized cost-effectiveness of measures and balanced emissions reductions among sectors and countries (cf. Schöpp et. al., 1999; Amann and Lutz, 2000). Subsequently an attempt was made to contrast the costs with overall benefits, which indicated annual costs of $€ 7.5$ billion as compared to benefits of $€ 17-30$ billion (Holland, M, 1999). The use of national emission ceilings gave individual countries full flexibility with respect to implementation and opened up for use of economic instruments (fuel taxes, road pricing, fiscal incentives, etc.) in addition to the pre-existing concentration value requirements in various $\mathrm{EU}$ directives.

As explained in Chapter 2 of this report the overall focus in the European Union has shifted from a concept based on 'critical loads to ecosystems' to one based on 'health benefits'. With this more anthropocentric focus we have also seen increased emphasis in the EU on use of actual cost-benefit analysis to check whether reductions are based on targets that 
are worthwhile overall, in that the monetized benefits are capable of offsetting the costs imposed to the various countries and the relevant sectors.

From a Nordic perspective, a basic concern with revision of the protocol is that the altered assessment principles and implications of the shift from a joint acidification-ozone assessment to one that is only healthbased should be addressed. The impetus for regional air pollution conventions originates to a large degree from the Nordic countries and a growing scientific understanding that impacts of transboundary air pollution caused acidification of lakes and forests. The shift towards human-health based assessment criteria, based not only on ozone but on effects of primary and secondary particulates, will potentially increase interest in implementing revised emissions ceilings among more continental EU member states with higher population densities. The shift may also result in a different emphasis with regard to allocation of emissions control requirements, with less weight accorded to emissions affecting the relatively sparsely populated Nordic region. The RAINS cost-effectiveness modelling that was undertaken in preparation of the 1999 Gothenburg Protocol appears to have combined stringency with a number of pragmatic considerations. Overall the new GAINS cost-benefit framework should provide for more consistency as well as transparency in accounting for the relevant benefits. Nevertheless, in assuring effectiveness from the Nordic perspective, and as long as ecosystem values cannot be adequately monetized, it will be relevant to check the implications of the revised reduction ceilings in relation to the original modelling.

To increase the overall effectiveness of the protocol additional signatories and ratifications will be required. From a Nordic perspective it would be of particular interest if Russia became a signatory to the protocol, as well-known transboundary impacts in the Nordic area result from emissions in north-western Russia. $\mathrm{SO}_{2}$-emissions from just one 'hotspot', the Pecheganikel industrial complex in Nikel near Murmansk, are equivalent to $\mathrm{SO}_{2}$-emissions from all sources in Finland and Norway (Stebel et. al., 2007) ${ }^{7} .26-44 \%$ reductions relative to 1990 (for a specified 'pollution emissions management area' (PEMA) including St. Petersburg, Kaliningrad and Murmansk) were foreseen in the protocol, but since reductions in the 1990's emissions of $\mathrm{NO}_{\mathrm{x}}$ and NMVOC are on the rise again. Projected 2010 emissions in European regions of Russia currently overshoot original forecasts by more than 500,000 tonnes for $\mathrm{SO}_{2}$ and $\mathrm{NO}_{\mathrm{X}}$ respectively (CIAM, 2007: 49; UNECE, 1999). The Russian Federation is a member of the UNECE LRTAP convention and was, under the Soviet Union, one of the convention's initiators. Russia has also signed the 1994 Oslo Protocol on further sulphur reductions. It is therefore an unfortunate paradox that Russia ended not signing the Gothenburg Protocol. It can be estimated that up to 10 per cent of the back-

\footnotetext{
${ }^{7}$ The operators Kolskaya GMK have recently announced plans to move production at Norilsk Nickel to another site near the border to Finland (Baltic Observer, June 10th, 2008).
} 
ground particle mass in rural areas in Finland may stem from Russia (cf. Norwegian Meteorological Institute, 2007:19).

Estonia too neither has signed nor ratified the Gothenburg Protocol, but will, as an EU member state, become subject to emissions ceilings under the EU NEC Directive. Poland, Italy, Greece and Ireland have signed but not yet ratified. It is likely that ratification by remaining EU member states would be helpful for the policy process, and lead to domestic reduction measures, especially in relation to non-compliance with $\mathrm{NO}_{\mathrm{X}}$ ceilings.

More generally under the cost-benefit perspective it is possible to assess for each of the signatories to the convention whether benefits sufficient to balance the costs imposed in policy implementation are likely to materialize. Modelling of country-specific costs and benefits were carried out in the Clean Air for Europe (CAFE) programme with respect to the Thematic Strategy on Air Pollution, and Table 5.1 provides an estimate of benefits based on improvements in life expectancy between the baseline scenario and the thematic strategy scenario. It appears that benefit-cost (BC) ratios will generally be highest in European countries with high population densities, whereas for countries that have low population densities and also are located at the periphery of Europe, such as Finland, benefits will not be sufficient to match the costs. Overall the benefit-cost ratios suggest that in the absence of substantial ecosystem benefits for Nordic countries, the balance of reduction commitments from an equity perspective could be shifted more towards countries with high population densities. (It is customary to assign the same VOLY across Europe, but it could be argued that due to differences in income levels, different VOLYs might be applied. Income levels per capita in Nordic countries are comparable with those in Germany and the Netherlands, and differentiated VOLYs would lower the BC ratios in some Eastern and Southern European countries, while improving Nordic BC ratios).

Table 5.1 Costs and benefits of the EU's Thematic Strategy for Air Pollution control for selected EU member states (a VOLY is €50k) in 2020; adapted from CAFE Scenario Analysis Report No. 7 (morbidity benefits and ecosystem benefits not included).

\begin{tabular}{lrrr}
\hline & Costs (million $€$ /yr) & Benefits (million $€$ /yr) & BC ratio \\
\hline Denmark & 86 & 164 & 1.9 \\
Finland & 63 & 21 & 0.3 \\
Sweden & 71 & 107 & 1.5 \\
Germany & 1401 & 5600 & 4.0 \\
UK & 776 & 2928 & 3.7 \\
Italy & 692 & 2450 & 3.5 \\
Netherlands & 328 & 1307 & 4.0 \\
Ireland & 94 & 86 & 0.9 \\
Poland & 633 & 2035 & 3.2 \\
Estonia & 15 & 14 & 0.9 \\
\hline
\end{tabular}

Whereas the Gothenburg Protocol managed to merge and balance efforts addressing a range of conventional pollutants, current efforts to curb 
emissions of $\mathrm{CO} 2$ and greenhouse gases drastically raise the question of whether and how climate change policy could and should be reflected in air pollution protocols. Obviously reductions in use of fossil fuels will alter emissions patterns, but projections are complicated by the variability of alternatives. Increased energy savings and use of renewable energy sources such as wind, solar and wave energy will imply significant benefits from reduced air pollution that can help balance the costs of climate change policy. Other alternatives, in particular biofuels including waste incineration, may result in increases in air pollutants, and although appropriate use of control technologies can help avoid such trends these technologies are available only at a cost; a fact which should not be neglected when designing future energy systems.

Whereas the framework for negotiations on greenhouse gas control is global, air pollutants remain a regional issue. In order to design costeffective and possibly efficient policies it will be important that the ancillary benefits of air pollution control are factored in when analysing climate policies. In the context of CLRTAP and amendments to the Gothenburg Protocol, climate change policy will enter the deliberations by means of improved and altered projections, possibly featuring more scenarios for trends in energy and transport systems as well as expected ETS prices. Current projections for emissions in 2020 do not reflect that the level of ambition with respect to control of greenhouse gases is likely to change. Due to the complexity of the issues, commitments and emission ceilings for the more traditional pollutants covered by the Gothenburg Protocol might be regarded as secondary to climate change policy, and the costs as secondary to commitments under a post-Kyoto framework. However, in order to allow for decision-making based on fairness in burden-sharing, the RAINS-GAINS modelling framework will need to capture projected climate change policies, resulting in more stringent commitments, as well as the separate air pollution control endeavours more accurately. The planned revision of the Gothenburg Protocol is scheduled for December 2009 and will coincide with the Conference of the Parties in Copenhagen under the UNFCCC. This timing does not allow much room for mutual adaptation of the two international regimes. 


\section{Conclusions}

The Gothenburg Protocol established a new multi-pollutant, multi-effect framework for regionally concerted action on control of conventional emissions $\left(\mathrm{SO}_{2}, \mathrm{NO}_{\mathrm{X}}, \mathrm{NH}_{3}\right.$ and $\left.\mathrm{VOC}\right)$, with the aim of reducing gaps between existing emissions and levels regarded as desirable to avoid negative impacts on vegetation and health. The Nordic parties to the protocol are obliged to close exceedance of critical levels by $100 \%$ for $\mathrm{SO}_{2}$, $25 \%$ for $\mathrm{NO}_{\mathrm{X}}$ and $60 \%$ for VOC. This entails considerable improvements on top of business-as-usual reductions, but also leaves some room for future progress. For $\mathrm{NH}_{3}$ the protocol allows Nordic countries a small increase in emissions due to Sweden and Norway. The multi-pollutant multi-effect framework offers the possibility to balance reduction efforts with costs and impacts, as derived from cost-effectiveness analysis guided by the RAINS model.

The review in this report shows that, according to the most recent and updated projections, Nordic countries are largely on track with regard to compliance with emissions ceilings. Significant reductions have been achieved, especially in $\mathrm{SO}_{2}$ emissions. A notable exception, however, is $\mathrm{NO}_{\mathrm{X}}$, where despite some progress, Denmark, Norway and Sweden will exceed the 2010 targets under the current legislation scenario. Norway will exceed the $\mathrm{NO}_{\mathrm{X}}$ ceiling by $24 \%$, as opposed to $7 \%$ and $4 \%$ respectively in the case of Denmark and Sweden. Finland is the only Nordic country which, according to projections, will comply with all four ceilings. Some effort is still required however as the $\mathrm{NO}_{\mathrm{X}}$ emission in Finland increased from 2005 to 2006, and is currently $14 \%$ above the ceiling. According to $\mathrm{SO}_{2}$ projections Norway will exceed this ceiling (by $14 \%$ ) in 2010 and Denmark will exceed the ceiling for VOCs (by $4 \%$ ). The majority of the other ratifying countries are projected to comply with the ceilings in 2010, but in addition to the three Nordic countries five to six other countries are also projected to have difficulties with the $\mathrm{NO}_{\mathrm{X}}$ ceiling (CIAM, 2007:35). Developments in transport and energy industry sectors explain the apparent difficulties with the $\mathrm{NO}_{\mathrm{X}}$ targets. For the relevant Nordic countries, Table 6.1 provides an overview of past and present emissions compared to projections for 2010 and the ceilings. 
Table 6.1 Gothenburg emissions ceilings, actual emissions in 1990 and 2006 as well as national projections for 2010

\begin{tabular}{|c|c|c|c|c|c|c|}
\hline & Pollutant: & Unit & $\begin{array}{r}\text { Actual } \\
1990\end{array}$ & $\begin{array}{l}\text { Ceiling } \\
2010^{1)}\end{array}$ & $\begin{array}{l}\text { Actual } \\
2006^{2)}\end{array}$ & $\begin{array}{r}\text { Projec- } \\
\text { tion } 2010\end{array}$ \\
\hline \multirow[t]{4}{*}{ Denmark } & Sulphur oxides $\left(\mathrm{SO}_{x}\right.$ as $\left.\mathrm{SO}_{2}\right)$ & $1000 t$ & 178 & 55 & 25 & 20 \\
\hline & Nitrogen oxides $\left(\mathrm{NO}_{x}\right.$ as $\left.\mathrm{NO}_{2}\right)$ & $1000 \mathrm{t}$ & 274 & 127 & 185 & 136 \\
\hline & $\begin{array}{l}\text { Non-methane volatile organic } \\
\text { compounds (NMVOC) }\end{array}$ & $1000 \mathrm{t}$ & 170 & 85 & 108 & 88 \\
\hline & Ammonia $\left(\mathrm{NH}_{3}\right)$ & $1000 \mathrm{t}$ & 108 & 69 & 75 & 65 \\
\hline \multirow[t]{4}{*}{ Finland } & Sulphur oxides $\left(\mathrm{SO}_{x}\right.$ as $\left.\mathrm{SO}_{2}\right)$ & $1000 \mathrm{t}$ & 249 & 116 & 84 & 98 \\
\hline & Nitrogen oxides $\left(\mathrm{NO}_{x}\right.$ as $\left.\mathrm{NO}_{2}\right)$ & $1000 t$ & 294 & 170 & 193 & 151 \\
\hline & $\begin{array}{l}\text { Non-methane volatile organic } \\
\text { compounds (NMVOC) }\end{array}$ & $1000 t$ & 229 & 130 & 132 & 130 \\
\hline & Ammonia $\left(\mathrm{NH}_{3}\right)$ & $1000 t$ & $(35)^{3)}$ & 31 & 36 & 31 \\
\hline \multirow[t]{4}{*}{ Norway } & Sulphur oxides $\left(\mathrm{SO}_{x}\right.$ as $\left.\mathrm{SO}_{2}\right)$ & $1000 t$ & 52 & 22 & 21 & 25 \\
\hline & Nitrogen oxides $\left(\mathrm{NO}_{x}\right.$ as $\left.\mathrm{NO}_{2}\right)$ & $1000 t$ & 208 & 156 & 191 & 193 \\
\hline & $\begin{array}{l}\text { Non-methane volatile organic } \\
\text { compounds (NMVOC) }\end{array}$ & $1000 t$ & 380 & 195 & 196 & 170 \\
\hline & Ammonia $\left(\mathrm{NH}_{3}\right)$ & $1000 \mathrm{t}$ & 23 & 23 & 23 & 24 \\
\hline \multirow[t]{4}{*}{ Sweden } & Sulphur oxides $\left(\mathrm{SO}_{x}\right.$ as $\left.\mathrm{SO}_{2}\right)$ & $1000 \mathrm{t}$ & 108 & 67 & 39 & 33 \\
\hline & Nitrogen oxides $\left(\mathrm{NO}_{x}\right.$ as $\left.\mathrm{NO}_{2}\right)$ & $1000 \mathrm{t}$ & 314 & 148 & 175 & 154 \\
\hline & $\begin{array}{l}\text { Non-methane volatile organic } \\
\text { compounds (NMVOC) }\end{array}$ & $1000 t$ & 373 & 241 & 195 & 183 \\
\hline & Ammonia $\left(\mathrm{NH}_{3}\right)$ & $1000 \mathrm{t}$ & 54 & 57 & 52 & 50 \\
\hline \multirow[t]{3}{*}{ Iceland } & Sulphur oxides $\left(\mathrm{SO}_{x}\right.$ as $\left.\mathrm{SO}_{2}\right)$ & $1000 t$ & 7 & - & 8 & n.a. \\
\hline & Nitrogen oxides $\left(\mathrm{NO}_{x}\right.$ as $\left.\mathrm{NO}_{2}\right)$ & $1000 t$ & 27 & 20 & 28 & n.a. \\
\hline & $\begin{array}{l}\text { Non-methane volatile organic } \\
\text { compounds (NMVOC) }\end{array}$ & $1000 \mathrm{t}$ & 13 & 5 & 7 & n.a. \\
\hline
\end{tabular}

1. Iceland's domestic targets: $30 \%$ reduction of $\mathrm{NO}_{x}$ and $50 \%$ reduction of NMVOC

2. Iceland is 2004

3. LRTAP cf. Isihii, 2001: 220

It has not been possible to identify studies that carefully disentangle the impacts of different measures on emissions. CIAM (2007:16) notes that $\mathrm{SO}_{2}$ emission reductions in Gothenburg Protocol countries from 19602020 are due to add-on treatment, changes in fuel mix and structural changes in economies, and that these three factors were likely to have contributed in approximately equal shares. Whereas changes in fuel mix and broader structural changes in the economies have taken place for reasons quite different than the protocol, they were actually part of the RAINS projections, and the protocol only attempted to accelerate and guide these reductions by introducing emissions ceilings. The add-on treatment which has been introduced is a result of regulation, but whether it stems from already existing regulations such as the EU Large Combustion Plant Directive, or whether implementation is due to the more stringent requirements stemming from the protocols seems to warrant analysis at a level of detail and inspection not undertaken anywhere in Europe to date. The flexible approach of the Gothenburg Protocol allows countries to apply their preferred approaches to control air pollution and aim tocomply with ceilings. In addition to thresholds and guide values that follow from various EU directives, the Nordic countries have introduced 
various domestic policy instruments with an economic orientation in order to control emissions.

From the ex-post perspective of the relatively few evaluation studies reviewed in this report, policy experience of note involving use of economic instruments includes:

- Denmark's particular success with a modest tax on $\mathrm{SO}_{2}$, which at the rate of just $€ 1.3 / \mathrm{kg}$ helped curb emissions significantly and attain the lowest emission level per unit of GDP in the OECD, despite the reliance on coal in the Danish power sector

- Finland's introduction of a revenue-neutral environmental tax reform that shifted a small part of the tax burden from labour to energy consumption via a combined carbon-energy tax. As a result of the tax shift, fuel use was reduced by approx. $5 \%$, with higher reductions for the most polluting and carbon-intensive fuels coal and heavy fuel oil

- Norway's introduction of a $\mathrm{NO}_{\mathrm{X}}$ tax in 2007 at the rate of $15 \mathrm{NOK} / \mathrm{kg}$ $\mathrm{NO}_{\mathrm{X}}\left(€ 1.9^{2007}\right)$ covering $55 \%$ of the total $\mathrm{NO}_{\mathrm{X}}$ emission. The tax allowed energy-intensive industries in 14 sectors a voluntary arrangement where the proceeds were paid into a fund to assist in financing abatement measures. The tax will be instrumental in compliance with the Gothenburg Protocol.

- Sweden's introduction of a road tax in Stockholm that reduced traffic and caused decreases in local emissions of $7 \%$ for $\mathrm{NO}_{\mathrm{X}}$ and $9 \%$ for primary particles. Sweden's tax on $\mathrm{NO}_{\mathrm{X}}$ for selected point sources at a rate of $40 \mathrm{SEK} / \mathrm{kg} \mathrm{NO}$ has also been shown to be significant for speeding up abatement and achieving a $30 \%$ reduction in emissions from these sources, of which half is directly attributable to the tax itself. Technical abatement measures introduced were efficient in that the abatement costs were below the $40 \mathrm{SEK} / \mathrm{kg} \mathrm{NO}\left(€ 4.28^{2008}\right)$ tax rate and in some cases even negative, indicating that win-win options had been identified. In 2008 the tax level was raised to $50 \mathrm{SEK} / \mathrm{kg}$ $\mathrm{NO}_{\mathrm{X}}\left(€ 5.35^{2008}\right)$. Sweden has also developed an effective system of differentiated port dues for ships according to emission levels.

From the ex-ante perspective numerous studies have been undertaken to figure out the most efficient approach to allocate reduction responsibilities among sectors while taking into account concerns about impacts on competitiveness for industries and distributional issues. While economic instruments, if applied to all emitters, will ensure that abatement is introduced wherever this is more advantageous than paying a tax, there are of course concerns among policy-makers which necessitate forecasting the impacts of measures agreed upon, and in particular projection of their abatement costs.

- Denmark has analysed which sectors can contribute most efficiently to close the gap between current Danish $\mathrm{NO}_{\mathrm{X}}$ emissions and the Gothen- 
burg ceiling for 2010. SCR catalysts for the fishing fleet as well as low$\mathrm{NO}_{\mathrm{X}}$ burners in industry seem to represent measures sufficient for compliance at a cost below $€ 1 / \mathrm{kg} \mathrm{NO}_{\mathrm{X}}$ whereas the Danish EPA assess most other measures to cost well above $€ 7 / \mathrm{kg} \mathrm{NO}$. Further $\mathrm{SO}_{2}$ reductions sufficient to attain the indicative 2020 ceiling can be implemented for less than $€ 0.5 / \mathrm{kg} \mathrm{SO}_{2}$, however.

- Norway has identified and analysed the costs of abatement and control measures for $\mathrm{NO}_{\mathrm{X}}$, and comes also to the conclusion that the most cost-effective options are available in the offshore and shipping sector. In particular rebuilding of ship engines and SCR could provide considerable $\mathrm{NO}_{\mathrm{X}}$ reductions at a cost of less than $€ 1 / \mathrm{kg} \mathrm{NO}_{\mathrm{X}}$, apparently sufficient to comply with the Gothenburg ceiling.

- Sweden in an analysis of available $\mathrm{NO}_{\mathrm{X}}$ reductions identified a range of options available between SEK 40 and $50 / \mathrm{kg} \mathrm{NO} \mathrm{NO}_{\mathrm{X}}(€ 4.28-5.35 / \mathrm{kg}$ $\mathrm{NO}_{\mathrm{X}}$ ) and has therefore decided to increase the $\mathrm{NO}_{\mathrm{X}}$ tax to SEK $50 / \mathrm{kg}$ $\mathrm{NO}_{\mathrm{X}}$ with effect from 2008. However, many industries (cement, refineries, forestry) are still not liable to the $\mathrm{NO}_{\mathrm{X}}$ tax, and, in the absence of detailed analysis on the issue, a range of reduction opportunities available at lower cost may thereby be forgone to safeguard the competitiveness of these sectors.

To date, the UNECE LRTAP protocols have not addressed selection of policy instruments, but have established emission ceilings within which countries have been free to design their own policies. While some countries are facing implementation shortfalls for specific pollutants, other countries may accomplish larger reductions than required. If an emissions trading system had been available, in the spirit of the UNFCC Kyoto Protocol, countries with surplus emission reductions could sell these to countries in deficit. However, there are certain reasons to be cautious about instituting an emissions trading system for the conventional air pollutants targeted by the Gothenburg Protocol. Although considerable transboundary transport is present, this differs from pollutant to pollutant and according to the location of the specific emission source. Under a system of trading, a country may potentially 'buy' some inexpensive emission reductions, but at the same time come to 'sell' the benefits of the emissions reductions that should accrue to its citizens, in turn potentially affecting the net benefit-cost (BC) ratio of the reduction measure. If Norway displaced $\mathrm{SO}_{2}$ reduction to, say, an eastern Europe country, most of the benefits would also accrue to the citizens in the eastern European country, as the regional dispersion of the secondary sulphate particles would only have affected Norway under exceptional circumstances. Kyoto is different in this regard because greenhouse gases cause damages only at the global level. Careful atmospheric modelling would be required for emissions trading for conventional pollutants, and we stipulate that trading would be an option for truly regional-scale pollutants such as $\mathrm{NO}_{\mathrm{X}}$, but less so for $\mathrm{SO}_{2}, \mathrm{NH}_{3}$ and primary- $\mathrm{PM}_{2.5}$ reductions, 
where a significant part of the benefits is available only within a $50 \times 50$ $\mathrm{km}$ range of the source (cf. Andersen et al., 2008).

The multi-pollutant, multi-effect model, RAINS, was used to guide negotiations for the Gothenburg Protocol. Extended to account for monetary benefits, the so-called RAINS-GAINS model complex constitutes the available modelling framework for simulating relative costs and benefits of proposed reduction measures to achieve on emissions ceilings. The RAINS model was subject to scientific review in 2004 and 2007 and on basis of these reviews is the internationally accepted tool for decisionsupport. Nevertheless it is important to bear in mind that many atmospheric processes are represented in a simplified form in the RAINSGAINS framework, and that even for much more advanced models accurately representing the non-linear, dynamic processes of atmospheric chemistry is a real scientific challenge. The RAINS-GAINS modelling framework can simulate many different scenarios for emissions reductions, but it would be useful to strengthen certain aspects. The sourcereceptor relationships in RAINS refer to model runs on the EMEP model, but once deviations occur from the specific single-pollutant $15 \%$ reduction scenario applied in the full EMEP model runs, it becomes rather uncertain whether the dynamics of atmospheric-chemistry nonlinearities are accurately captured in the RAINS framework. If the influence from a source-pollutant on a receptor-concentration is in reality non-linear, which frequently is the case, the scenarios are not unconditionally additive. It seems important to explore the uncertainties of the RAINS model in more depth by testing specific scenario results on a full 3D Eulerian atmospheric chemistry-transport model.

The effectiveness of the Gothenburg Protocol would be improved if more of the countries that participated in the negotiation phase would become signatories - as well as ratify the protocol! From a Nordic perspective greater involvement of the Russian Federation would be of particular interest, as Russia's emissions are now on the increase again. In addition, around 10 other countries, mainly former Soviet republics and Balkan countries, have not joined. Under the NEC Directive, EU member states face legal obligations to implement emissions ceilings, but financial and legal mechanisms could be devised to improve implementation, also among associated member states and third countries. The improved scientific understanding of the health impacts of air pollution should lead to inclusion of primary particles under the protocol, and can be expected to facilitate interest among a range of countries to take more active part in the protocol. From a Nordic perspective the original concern about the impacts of transboundary air pollution on forests and lakes persists, as the gaps between critical loads and actual emissions remain. It is not likely however that the more health-based assessment principles in the RAINSGAINS modelling framework will lead to the same allocation of reduction burdens and benefits as under the previous more ecosystem-based 
assessment principles, and it is advised that Nordic countries check the implications carefully in this regard. Moreover, the benefit-cost ratios under the related EU thematic strategy for air pollution (which used a similar assessment framework as in the RAINS-GAINS model) appear to be somewhat more advantageous for central European countries than for Nordic countries and other countries in the atmospheric periphery of the regional framework. 


\section{Annex: Projection methodologies}

\section{Introduction}

Energy consumption in 'energy industries', 'manufacturing and construction', and 'transport' is the most significant source of the emission of $\mathrm{SO}_{2}, \mathrm{NO}_{\mathrm{X}}$, and NMVOC. For Denmark these sectors constitute $80 \%, 94$ $\%$, and $38 \%$ of the total emission of $\mathrm{SO}_{2}, \mathrm{NO}_{\mathrm{X}}$, and NMVOC in 2006. For Finland these sectors constitute $73 \%, 88 \%$, and $39 \%$ of the total emission of $\mathrm{SO}_{2}, \mathrm{NO}_{\mathrm{X}}$, and NMVOC in 2006. For Sweden these sectors constitute $59 \%, 89 \%$, and $45 \%$ of the total emission of $\mathrm{SO}_{2}, \mathrm{NO}_{\mathrm{X}}$, and NMVOC in 2006. Therefore, projections of energy consumption and the associated emissions are important for the validity of the overall projections. For Denmark, Finland and Sweden a short description of the energy projections is presented below.

\section{Denmark}

The Danish energy projections are developed by the Danish Energy Authority (2008). The basis for the Danish projections is the models EMMA (economical model) and RAMSES (technical-economical simulation model). The base scenario is a 'business as usual' scenario i.e. no new political initiatives. The projections are based on:

- energy statistics

- economical growth

- fuel prices

- quota/non-quota covered energy consumption

- $\mathrm{CO}_{2}$ quota prices

- public subdidies/taxes

- planned savings

- transport

- North Sea

- heat and power sector

In the new energy statistics used in the projections the historical background has been improved. The expected economic growth is based on the 2015 plan from the Ministry of Finance (Mod nye mål - Danmark 2015). For fossil fuels the fuel prices are based on the projections WEO2007 by IEA, whereas the prices for biofuels are based on national conditions. The ratio between quota/non-quota covered energy consumption is assumed to be constant in the projection period. However, the 
energy consumption in the quota covered sectors will be regulated by the quotas allocated by EU as well as the $\mathrm{CO} 2$ quota prices.

The taxes on energy are kept constant (in 2006 prices) during the projection period. The same is the case for subsidies as they are also kept constant. EMMA is used for projection of road transport whereas the model is assumed to be too uncertain for aviation, navigation and train. For these transport systems no changes in the assumptions have been introduced. Consumption of energy in the Danish oil extraction industry in the North Sea depends on 1) production from known sources with known technology, 2) production from new sources, and 3) production with new technology. E.g. implementation of BAT will improve the extraction efficiency. The energy consumption in the heat and power sector is projected by using RAMSES. RAMSES includes information on all Nordic energy plants, fuel type, efficiency, operation costs.

The modelling is performed as an iterative process. The projection modelling results in the data for the consumption of different fuels in different sectors to 2025 .

\section{Finland}

The Finnish projections are described in detail in the report 'Kansallisen energia- ja ilmastostrategian laadinnassa käytetyt skenaariot' and summarized in Statsrådet (2005). The description below is only based on Statsrådet (2005). The basis for the projections is:

- ' economic development in Finland and in the export markets'

- 'population and demographic structure'

- 'development of energy prices on the world market'

The growth factor is expected to be $2.5 \%$ falling to $2 \%$ in 2025 and in the same period the energy intensity in the industry is expected to decrease. The short-term scenario has been developed by Finnish Economic Research Institute whereas the long-term scenario has been developed with input from the Government Institute for Economic Research , Ministry of Finance, and Ministry of Trade and Industry (from 01.01.08: Ministry of Employment and the Economy).

The development in energy consumption (per fuel) within different sectors was projected from 2003 to 2025 . The total consumption in primary energy has increased from 1487 PJ in 2003 to 1678 PJ in 2025 i.e. $12.8 \%$ increase. Nuclear power constitutes $16 \%$ of total energy consumption in 2003 increasing to $21.5 \%-23.1 \%$ in $2010-2025$. 


\section{Sweden}

The Swedish energy projections (Andréasson et al., 2005) are based on:

- general conditions

- energy consumption

- energy supply

The projections combine a system analysis perspective with a socioeconomic perspective. The modelling by the energy authorities has been carried out in collaboration with a number of other authorities. The general conditions include: economic development, fuel prices, heat and power prices, and the price of $\mathrm{CO}_{2}$ emissions. The economic projections are performed by means of EMEC (Environmental Medium-term Economic Model) developed by the National Institute of Economic Research. Fuel prices are based on the World Energy Outlook by IEA. Heat and power prices/consumption are based on the MARKAL-NORDIC model (market allocation model) and PoMo (power model). The price of the $\mathrm{CO}_{2}$ emission will be included in coming projections.

Energy consumption is projected for the industrial sector, residential/commercial/institutional sectors, and transport. Energy consumption in the industrial sector is projected by using EMEC, MARKAL-NORDIC model as well as the DoS model - Demand and Supply model. For the projections in the residential/commercial/institutional sectors statistics on degree days are included in the above-mentioned models. The gasoline and diesel consumption is projected by using top-down models including information on gasoline consumption in base year, \%-change in prices, price elasticity, \%-change in personal income, income elasticity, and a trend variable. For diesel further factors are included. The projections are compared and balanced with projections made by SIKA. SIKA uses the models SAMPERS and SAMGODS.

Energy supply, i.e. net import of fuels, is determined by a number of factors: development in energy demand, fuel prices, political instruments, costs regarding existing plant, annual production of power from hydro power and nuclear plants, life-time of public installations, investment and production costs for new plant, development of technologies, limitations in the potential for different production techniques not captured by MARKAL-NORDIC model, energy systems in neighbour countries, capacity regarding transfer of energy to neighbouring countries, and potential for development of energy infrastructure.

The projection models are operated iteratively and most of the submodels interact with each other. The projection modelling results in future consumption data for different fuels in different sectors. 


\section{References}

Agren, Christer, Peringe Grennfelt, Matti Johansson, Rob Maas (chair), Simone Schucht, Les White1, Assessment of the similarities and differences between the GAINS and the RAINS models; review of GAINS Conclusions of the review group. Report of the 2007 GAINS review (February 26, 2007) http://www.iiasa.ac.at/rains/reports/gains -review.pdf

Amann, Markus, Janusz Cofala, Chris Heyes, Zbigniew Klimont, Reinhard Mechler, Max Posch, Wolfgang Schöpp, 2004, The RAINS model. Documentation of the model approach, prepared for the RAINS peer review 2004, pp. 156 .

Amann, M. and Lutz, M., 2000, The revision of the air quality legislation in the European Union related to ground-level ozone, Journal of Hazardous Materials 78: 41-62.

Amann, M. 2001, Emission inventories, emission control options and control strategies: a review of recent developments, Water, Air and Soil Pollution 130: 43-50.

Amann, M., I. Bertok, R. Cabala, J. Cofala, C. Heyes, F. Gyarfas, Z. Klimont, W. Schöpp, F. Wagner, 2005, Target Setting Approaches for Cost-effective Reductions of Population Exposure to Fine Particulate Matter in Europe. Background paper for the meeting of the CAFE Working Group on Target Setting and Policy Advice, February 4, 2005.

Extended Version for the CAFE Steering Group February 13, 2005.

http://www.iiasa.ac.at/rains/CAFE_files/ CAFE-B-full-feb3.pdf

Andersen, Mikael Skou, Niels Dengsøe and Anders Branth Pedersen, 2001, An Evaluation of the Impact of Green Taxes in the Nordic Countries (TemaNord 2001: 561), Nordic Council of Ministers. Andersen, M.S., Frohn, L.M., Nielsen, J.S., Nielsen, M., Jensen, J.B., Jensen, S.S., Christensen, J. \& Brandt, J., 2008, EVA - a non-linear Eulerian approach for assessment of health-cost externalities of air pollution, paper presented at
EAERE conference in Gothenburg, June 2008.

Andersen, M.S., Barker, T., Christie, E., Ekins, P., Gerald, J.F., Jilkova, J., Junankar, S., Landesmann, M., Pollitt, H., Salmons, R., Scott, S. and Speck, S. (eds.), 2007a, Competitiveness Effects of Environmental Tax Reforms (COMETR). Publishable Final Report to the European Commission, DG Research and DG TAXUD (Summary Report). National Environmental Research Institute, University of Aarhus. $111 \mathrm{pp}$. http://www.dmu.dk/Pub/COMETR_Sum mary Report.pdf

Andersen, M.S., Barker, T., Christie, E., Ekins, P., Gerald, J.F., Jilkova, J., Junankar, S., Landesmann, M., Pollitt, H., Salmons, R., Scott, S. and Speck, S. (eds.), 2007b, Competitiveness Effects of Environmental Tax Reforms (COMETR). Final report to the European Commission. National Environmental Research institute, University of Aarhus. 543 pp. http://www.dmu.dk/Pub/COMETR_Fina 1 Report.pdf

Andréasson, J., López, E.C., Jakobsson, T., Jönsson, A. \& Larsson, M. 2005. Energimyndighetens metodik för långsigtiga energiprognoser. Statens energimyndighet, ER 2005:36.

Bach, H., Andersen, M.S., Illerup, J.B., Møller, F., Birr-Pedersen, K., Brandt, J., Ellermann, T., Frohn, L.M., Hansen, K.M., Palmgren, F., Nielsen, J.S. \& Winther, M. 2006: Vurdering af de samfundsøkonomiske konsekvenser af Kommissionens temastrategi for luftforurening. $90 \mathrm{~s}$. - Faglig rapport fra DMU nr. 586. http://fagligerapporter.dmu.dk Bartnicki, Jerzy: Non-Linear Effects in the Source-Receptor Matrices Computed with the EMEP Eulerian Acid Deposition Modell. EMEP/MSC-W, Note 40/2000, ISSN 0332-9879, pp. 34.

CIAM, 2007, Review of the Gothenburg Protocol. Report of the Task Force on Integrated Assessment Modelling and the Centre for Integrated Assessment Modelling (CIAM report 1/2007), Dutch Centre for Integrated Assessment. 
Cuvelier, C., P. Thunis, R. Vautard, M. Amann, B. Bessagnet M. Bedogni, R. Berkowicz, J. Brandt, F. Brocheton, P. Builtjes, B. Denby, G. Douros, A. Graf, O. Hellmuth, C. Honore, J. Jonson, A. Kerschbaumer, F. de Leeuw, N. Moussiopoulos, C. Philippe, G. Pirovano, L. Rouil, M. Schaap, R. Stern, L. Tarrason, E. Vignati, L. Volta, L. White, P. Wind, A. Zuber, 2007: "CityDelta: A model intercomparison study to explore the impact of emission reductions in European cities in 2010". Atmospheric Environment, Volume 41, Issue 1, January 2007, Pages 189-207

Danish Energy Authority, 2007, $\mathrm{SO}_{2}$ og $\mathrm{NO}_{X^{-}}$-kvoteregulering af de store kraftvcerker (www.ens.dk at 11.02.2008).

Danish Energy Authority, 2008. Basisfremskrivning af Danmarks energiforbrug frem til 2025. http://www.ens.dk/graphics/ENS_Energipolitik/strategi_vis ionaer/basisfremskrivning_2007.pdf

Denmark 2007. Submission of Emissions for 1980-2006 and Projections for 2010, 2015 and 2020. Uploaded 20 December 2007. Available at http://cdr.eionet.europa.eu/dk/eu/nec/envr2pifg . DG Environment, 2004, Comparison of the EU and US approaches Towards Acidification, Eutrophication and Ground Level Ozone, DG Environment.

Dragsund, E., K. Aunan, O. Godal, G.P. Haugom \& B. Holtsmark, 1999, Utslipp til luft fra oljeindustrien - Tiltak, kostnader og virkemidler, Oslo (Cicero Report 1999: 2).

ECON, 2007, Ncringsmessige konsekvenser av økt avgift på $\mathrm{NO}_{\mathrm{x}}$, Oslo: ECON (Rapport 2007 - 114).

Elofsson, Katarina \& Ing-Marie Gren, 2004, "Kostnadseffektivitet i svensk miljöpolitik för Östersjön - en utvärdering" pp.57-68 in Ekonomisk Debatt vol.32 no. 3 .

ENDS, 2007, EU struggling to meet air pollution emission caps (ENDS Europe Daily 13.12.2007).

ENDS, 2008a, Power plant pollution 'could be cut considerably' (ENDS Europe Daily 08.05.2008).

ENDS, 2008b, Europe 'needs strong green market measures', (ENDS Europe Daily, 25.04.2008).

ENDS, 2008c, Environment 'comes before competitiveness', ENDS Europe Daily, 14.03.2008).
ENDS, 2008d, Pan-EU study shows worsening air quality, (ENDS Europe Daily, 04.02.2008).

Environmental Protection Agency, 1996, Miljökonsekvenser av $\mathrm{NO}_{x}$-avgiften, Stockholm.

Environmental Protection Agency, 1997, Svavelskatt och NO-avgift - Utvärdering, Stockholm.

Environmental Protection Agency, 2002, Utsläpp av ammoniak och lustgas från förbränningsanläggningar med SNCR/SCR, Stockholm.

Environmental Protection Agency, 2003, Kväveoxidavgiften - et effektivt styrmedel. Utvärdering av $\mathrm{NO}_{x}$-avgiften, Stockholm.

Environmental Protection Agency, 2004a, Förslag för kostnadseffektiv minskning av kväveoxidutsläpp - Kväveoxidavgift och handelssystem för utsläppsrätter. Slutrapportering av regeringsuppdrag gällande översyn av kväveoxidavgift för stationära förbränningsanläggningar m.m., Stockholm.

Environmental Protection Agency, 2004b, Fortsatt grön skatteväxling - förslag till utformning, Stockholm.

Environmental Protection Agency, 2005, Förslag till breddning och uppdelning av kväveoxidavgiften, Stockholm.

Environmental Protection Agency, 2006a, Analyse af Danmarks muligheder for at reducere emissionerne af NOx i 2010 (Miljøprojekt 1104), Copenhagen.

Environmental Protection Agency, 2006b, Samfundsøkonomisk analyse af $\mathrm{NO}_{x} \mathrm{re}$ duktion (bilagsrapport), København: Miljøstyrelsen.

Environmental Protection Agency and the Swedish Energy Agency, 2006, Ekonomiska styrmedel i miljöpolitiken, Stockholm.

EurActiv.com, www.euractiv.com

European Parliament and the Council, 2001, Directive 2001/81/EC on national emission ceilings for certain atmospheric pollutants.

Finland, 2006, NEC report: final emissions for 2004. Uploaded 18 December 2006. Available at http://cdr.eionet.europa.eu/fi/eu/nec/envryaniq.

Finland, 2007a, Annual Greenhouse Gas Inventory Report to the UNFCCC for years 1990-2005 by Finland under the Decision No 280/2004/EC. Uploaded 16 April 2007. Available at http://cdr.eionet.europa.eu/fi/eu/colrdtesw. 
Finland, 2007b, NEC report: final emissions for 2005, preliminary emissions for 2006 and projections for 2010. Uploaded 04 December 2007. Available at http://cdr.eionet.europa.eu/fi/eu/nec/envr 1 whuq.

Førsund, F.R. \& E. Nævdal, 1998, "Efficiency Gains Under Exchange-Rate Emission Trading" pp.403-23 in Environmental and Resource Economics, vol. 12 no. 4 .

GAINS Review: "Assessment of the similarities and differences between the GAINS and the RAINS models; review of GAINS Conclusions of the review group" - Christer Agren, Peringe Grennfelt, Matti Johansson, Rob Maas (chair), Simone Schucht, Les White.

http://www.iiasa.ac.at/rains/reports/gains -review.pdf

Grover, Velma I., 2007, “Acid Rain” pp.24 in Paul Robbins (ed.), Encyclopedia of Environment and Society, Los Angeles (CA) et al: Sage Publications.

Harrington, Winston \& Richard D. Morgenstern, 2004, "Economic Incentives versus Command and Control What's the Best Approach for Solving Environmental Problems" pp.13-17 in Resources fall/winter 2004.

Heidam, Niels Z. \& Jytte B. Illerup, 2004, "National Assessment Report for Denmark" pp.13-28 in Bartnicki, J. \& Lövblad, G. (Eds), Addendum to EMEP Assessment Part II. National Contributions, Oslo: Norwegian Meteorological Institute.

Hildén, M., J. Lepola, P. Mickwitz, A. Mulders, M. Palosaari, J. Similä, S. Sjöblom and E. Vedung, 2002, Evaluation of environmental policy instruments - a case study of the Finnish pulp \& paper and chemical industries, (Monographs of the Boreal Environment Research no.21).

Hiltunen, Marjukka, 2004, Economic environmental policy instruments in Finland, Helsinki: Finnish Environment Institute.

Holland, M., 1999, Cost-effective control on acidification and ground-level ozone, AEA Technology.

Iceland, 2006, UNFCCC data 1990-2004 (2006 delivery). Uploaded 10 October 2006. Available at http://cdr.eionet.europa.eu/is/un/Framew ork Convention on Climate Change/envrstolw
IIASA, 2006, 'Measures_Th strategy. Analysis for the Thematic Strategy Scenario. 'Excel spreadsheet containing measures suggested by the RAINS model to meet reduction goals in Thematic Strategy for Air pollution. International Institute for Applied Systems Analysis (IIASA), Laxenburg, Austria. IIASA, 2007, Cost-optimized reductions of air pollutant emissions in the EU Member States to address the environmental objectives of the Thematic Strategy on Air Pollution, Laxenburg, Austria: IIASA.

Isaksson, Lena Höglund, 2005, “Abatement costs in response to the Swedish charge on nitrogen oxide emissions" pp.102-120 in Journal of Environmental Economics and Management vol.50.

Ishii, A., 2001, "Merging the EU acidification strategy: Evaluating the 1999 Gothenburg protocol to abate acidification, eutrophication and ground-level ozone", RECIEL, 10:2, 210-226.

www.blackwell-synergy.com/doi/pdf/10.1111/14679388.00277? cookieSet $=1$

Ketzel, Matthias \& Finn Palmgren, 2008 (in press), Opdatering af vurdering af anvendelse af SCR-katalysatorer på tunge køretøjer som virkemiddel til nedbringelse af NO forureningen i de største danske byer, (NERI report 660), http://www2.dmu.dk/Pub/FR660.pdf, NERI.

Klaassen, G.A.J., F.R. Førsund \& M. Amann, 1994, "Emission Trading in Europe with an Exchange Rate" pp.30530 in Environmental and Resource Economics, vol.4 no.4.

Mareckova, K., Gager, M., Gugele, B. \& Kampel, E., 2007, NEC Directive status report 2006 Member States' reporting under Directive 2001/81/EC of the European Parliament and of the Council of 23 October 2001 on national emission ceilings for certain atmospheric pollutants. 32 p. EEA Technical report No 15/2007.

Mickwitz, Per, 2003, “A Framework for Evaluating Environmental Policy Instruments - Context and Key Concepts" pp.415-36 in Evaluation vol.9 no.4.

Milieu, 2004a, Assessment of the Effectiveness of European Air Quality Policies and Measures - Final report on task 3.3, Milieu.

Milieu, 2004b, Assessment of the Effectiveness of European Air Quality Poli- 
cies and Measures - Final report on task 3.5, Milieu.

Ministry for the Environment in Iceland, 2002, Welfare for the Future - Iceland'sNational Strategy for Sustainable Development 2002-2020, Reykjavik.

Ministry for the Environment in Iceland, 2006, Welfare for the Future - Iceland's National Strategy for Sustainable Development. Statistical Indicators 2006, Reykjavik.

Ministry of Finance et al, 1999, Evaluering af grønne afgifter og erhvervene, Copenhagen: Schultz.

Ministry of Finance, 2008, The history of green taxes in Norway (at www.regjeringen.no).

Ministry of Taxation, 2007, Et omkostningseffektivt CO2- og energiafgiftssystem i en økonomi med CO2-kvoter, Copenhagen.

Ministry of the Environment, 2002, Air Pollution Control Programme 2010, Helsinki: Ministry of the Environment.

Ministry of the Environment, 2005, National Reporting on Atmosphere/Air Pollution, Helsinki.

Ministry of the Environment, 2007, Regjeringens miljøpolitikk og rikets miljøtilstand (Stortingsmelding nr. 26 2006/2007), Oslo.

Ministry of the Environment, 2008a, Ny avtale skal redusere miljøfarlige utslipp av NOx, Oslo (www.regeringen.no).

Ministry of the Environment, 2008b, Ökad klimatsatsning i budgeten för 2008 (www.regeringen.se).

Ministry of the Environment and Natural Resources, 1993, Morot och piska för bättre miljö - Förslag om utvidgad användning av ekonomiska styrmedel mot kväveoxidutsläpp, Stockholm.

NEBEI, 2005, Policy Instruments to Reduce Air Pollution, (Draft summary report of the workshop by the rapporteur of the Network of Experts on Benefits and Economic Instruments (NEBEI) in collaboration with the secretariat).

Norway, 2007, EMEP emission data for 2005. Table2a_projections_main_pollutants.xls. Uploaded 15 February 2007. Available at http://cdr.eionet.europa.eu/no/un/CLRT AP/colqv0ipg/colrdlzaa/envrdlz1g

Norway, 2008, EMEP emission data for 2006. Uploaded 15 February 2008. Available at
http://cdr.eionet.europa.eu/no/un/CLRT AP/colqv0ipg/colr7vdcq .

Norwegian Official Report, 1995, Virkemidler i miljøpolitikken (NOU 1995:4), Oslo.

Norwegian Meteorological Institute, 2007, Transboundary air pollution by main pollutants and PM: The Russian Federation, MSC-W Data note 1/2007, ISSN1890-0003.

OECD, 1999, Denmark - Environmental Performance Reviews, Paris: OECD.

OECD, 2001a, Finland - OECD Environmental Performance Reviews, Paris: OECD.

OECD, 2001b, Iceland - Environmental Performance Reviews, Paris: OECD.

OECD, 2001c, Norway - Environmental Performance Reviews, Paris: OECD.

OECD, 2004, Sweden - Environmental Performance Reviews, Paris: OECD.

OECD, 2007, Instrument Mixes for Environmental Policy, Paris: OECD.

OECD, 2008, Denmark - Environmental Performance Reviews, Paris: OECD.

Palmgren, F., M. Glasius, P. Wåhlin, M. Ketzel, R. Berkowicz, S.S. Jensen, M. Winther, J.B. Illerup, M.S. Andersen, O. Hertel, P.S. Vinzents, P. Møller, M. Sørensen, L.E. Knudsen, B. Schibye, Z.J. Andersen, M. Hermansen, T. Scheike, M. Stage, H. Bisgaard, S. Loft, C. Lohse, K.A. Jensen, V. KofoedSørensen and P.A. Clausen, 2005a, Luftforurening med partikler i Danmark, (Miljøprojekt nr. 1021), Copenhagen: Environmental Protection Agency.

Palmgren, F., R. Berkowicz \& C.L. Fogh, 2005b, Vurdering af konsekvenserne af indførelse af forskellige typer af miljøzoner i København, National Environmental Research Institute.

Palmgren, F., R. Berkowicz, M. Ketzel \& M. Winther, 2007, Vurdering af anvendelse af SCR-katalysatorer på tunge køretøjer som virkemiddel til nedbringelse af NO2-forureningen i de større danske byer, National Environmental Research Institute.

Porter, M.E. \& C. vand der Linde, 1995, "Toward a new conception of the environment-competitiveness relationship" pp.97-118 in Journal of Economic Perspectives vol.9.

Review of the RAINS Integrated Assessment Model - Reference

ENV.C1/SER/2003/0079. Final version 2004-10-08, pp. 42. 
http://europa.eu.int/comm/environment/a ir/cafe/activities/pdf/rain model.pdf

Schöpp, W., Amann, M., Cofala, J., Heyes, C. and Klimont, Z., 1999, Integrated assessment of European air pollution emission control strategies, Environmental Modelling and Software 14:1-9.

SFT (Statens Forureningstilsyn), 2006, Tiltaksanalyse for NOx. Utredning av mulige NOx-reduserende tiltak innenfor energianleggene på sokkelen, innenlands skipsfart og fastlandsindustrien.

Sjöfartsverket, 1999, Utvärdering av miljödifferentierade avgifter för sjöfarten, Sjöfartsverket.

Slentø, Erik, Finn Palmgren, Flemming Møller \& Anders Branth Pedersen, 2008, $\mathrm{NO}_{x} / \mathrm{NO}_{2}$ forureningen i Danmark, National Environmental Research Institute of Denmark, University of Aarhus (note).

SOU, 2003, Svåra skatter (SOU 2003-38), Swedish Government Official Report, Stockholm.

Speck, S., M.S. Andersen, H.Ø. Nielsen, A. Ryelund \& C. Smith, 2006, The Use of Economic Instruments in Nordic and Baltic Environmental Policy 2001-2005, Nordic Council of Ministers.

Statistisk Sentralbyrå, 2008, Stor utfordring å opfylle $\mathrm{NO}_{x}$-målet (www.ssb.no 12.02.2008).

Statsrådet, 2005. Riktlinjer för energi- och klimapolitiken under den närmaste framtiden - en nationell strategi för verkst"llandet av Kyotoprotokollet. Bakgrundsrapport. Statsrådet, Finland, Textutkast 30.11.2005. http://www.tem.fi/index.phtml?1=sv\&s=164

Stebel, K, Christensen, G, Derome, J, Grekelä, I, eds, 2007, State of the Environment in the Norwegian, Finnish and Russian border area, The Finnish Environment Issue 6, Rovaniemi: Lapland Regional Environment Centre.

Sweden, 2007, National inventories and emission projections (Directive 2001/81/EC)_delivery 2007. Uploaded 28 December 2007. Available at http://cdr.eionet.europa.eu/se/eu/colp931 qa/envr3tnvg.

Tarrasón, L., J. E. Jonson, H. Fagerli, A. Benedictow, P. Wind, D. Simpson and
H. Klein, Transboundary acidification, eutrophication and ground level ozone in Europe, Part III, Source-Receptor relationship, EMEP Report 1/2003. Norwegian Meteorological Institute, Oslo, 2003.

The European Parliament and the Council, 2001, National emission ceilings for certain atmospheric pollutants (Dir. 2001/81/EC), amended by Council Directive $2006 / 105 / \mathrm{EC}$ of 20 . november 2006.

UNECE, 1979, The 1979 Convention on Long-range Transboundary Air Pollution.

UNECE 1998, Report of the Fifteenth Session of the Executive Body, http://www.unece.org/env/documents/19 98/ece/eb/ece.eb.air.53.e.pdf

UNECE, 1999, Protocol to the 1999 Convention on Long-Range Transboundary Air Pollution to Abate Acidification, Eutrophication, and Ground-Level Ozone.

UNECE, 2007, Draft 2008 Workplan, Working Group on Strategies and Review, http://www.unece.org/env/documents/2007/eb/EB/ece.eb.air.2007.9.e.pdf

UNECE, 2008, Draft Plan for the Revision of the Protocol, Working Group on Strategies and Review, http://unece.org/env/documents/2008/EB /wg5/ece.eb.air.wg.5.2008.5.e.pdf.

van Loon, M., Roemer, M. G. M., Builtjes, P. J. H., Bessagnet, B., Rouill, L., Christensen, J., Brandt, J., Fagerli, H., Tarrason, L., Rodgers, I., Stern, R.,

Bergström, R., Langner, J., Foltescu, V., 2004: "Model inter-comparison. In the framework of the review of the Unified EMEP model". TNO-report, TNOMEPO - R 2004/282, pp. 86, June 2004. Vehmas, Jarmo, 2005, “Energy-related taxation as an environmental policy tool - the Finnish experience 1990-2003" pp.2175-2182 in Energy Policy vol.33 issue 17.

Wuester, H., 2001. Factors responsible for emission changes 1960-2020, Vienna: IIASA.

www.unece.org/env/tfiam/26meeting/fact ors tfaim26.ppt

www.unece.org 



\section{Summary in Danish}

1. Göteborg-protokollen (1999) har til formål at begrænse emissioner af $\mathrm{SO}_{2}, \mathrm{NO}_{\mathrm{x}}, \mathrm{NH}_{3}$ og VOC til et niveau, hvor emissionerne ikke længere er kritiske for økosystemer og for befolkningernes sundhed. For at opfylde målet forpligtede Danmark, Finland, Norge og Sverige, som alle underskrev protokollen, sig til at indføre lofter (gældende til 2010) for de fire pågældende emissionstyper. Lofterne for $\mathrm{SO}_{2}$ og VOC er lavere, end de lofter som andre lande under protokollen har forpligtet sig til, mens de nordiske $\mathrm{NO}_{\mathrm{X}}$-lofter tilsvarer forpligtelserne i lande udenfor Norden. Det kan generelt konstateres, at der blandt de fire nordiske protokolunderskrivere har været markante emissionsreduktioner for alle fire emissionstyper. Island har ikke underskrevet protokollen, men Island har nationale reduktionsmål, som tilsvarer de andre fire nordiske landes - Island har dog oplevet stigende emissioner af $\mathrm{SO}_{2}$ og $\mathrm{NO}_{\mathrm{X}}$.

2. De nyeste nationale fremskrivninger af udviklingen i emissionerne viser, at de nordiske lande er godt på vej til at komme under emissionslofterne for 2010. Tidligere fremskrivninger har dog vist, at der kunne opstå problemer med at nå ned til $\mathrm{NO}_{\mathrm{X}}$-loftet - det er der stadig, idet både Danmark, Norge og Sverige kan få problemer med at nå $\mathrm{NO}_{\mathrm{X}}$-målet. Senest har Finland oplevet stigende $\mathrm{NO}_{\mathrm{X}}$-emissioner, men Finland ser dog fortsat ud til at nå målet i 2010. Generelt er mankoerne i de nordiske $\mathrm{NO}_{\mathrm{X}}$-fremskrivninger ikke så store som tidligere. I tillæg til $\mathrm{NO}_{\mathrm{X}}$-problemerne har Danmark problemer med at nå VOC-målet.

3. Analyserne viser generelt, at det største problem i forhold til $\mathrm{NO}_{\mathrm{X}^{-}}$ reduktioner, er den stigende aktivitet i de nordiske landes transportsektorer. De mest omkostningseffektive tiltag til en yderligere begrænsning af $\mathrm{NO}_{\mathrm{X}}$-emissionerne kan dog tilsyneladende findes indenfor offshore sektoren og skibsindustrien, hvor der kan identificeres tiltag til en pris under $€ 1 / \mathrm{kg} \mathrm{NO}_{\mathrm{X}}$. Det vil være muligt for de nordiske lande at påtage sig endnu strengere $\mathrm{SO}_{2}$-lofter end under Göteborg-protokollen til en pris på under $€ 1 / \mathrm{kg} \mathrm{SO}_{2}$, mens prisen for yderligere $\mathrm{NO}_{\mathrm{X}}$-reduktioner vil være mindst $€ 7 / \mathrm{kg} \mathrm{NO}$. Der er ikke identificeret estimater for $\mathrm{VOC}$ og $\mathrm{NH}_{3}$.

4. Fleksibiliteten i Göteborg-protokollen er stor i kraft af, at det er helt op til de enkelte lande, hvordan de vil leve op til målene. En litteraturgennemgang af ex post-analyser af gennemførte tiltag primært med fokus på nationale økonomiske instrumenter - indikerer, at økonomiske incitamenter har fremmet strukturelle ændringer i Norden i retning af et lavere og renere energiforbrug. 
Samtidig har de økonomiske incitamenter udløst en række industrielle tiltag for at begrænse udledningerne rundt omkring i de nordiske lande. Danmark har med en $\mathrm{SO}_{2}$-afgift på kun $€ 1.3 / \mathrm{kg} \mathrm{SO}_{2}$ opnået den laveste $\mathrm{SO}_{2}$-udledning målt pr. enhed GDP i hele OECD. Finland har gennem en grøn skattereform mindsket arbejdsmarkedsbeskatningen og i stedet indført en $\mathrm{CO}_{2}$ /energiafgift, som har ført til en $5 \%$ reduktion i energiforbruget - en afgift som især har haft betydning for kul og tung brændselsolie. Sverige har succesfuldt indført en havneafgift for skibe som anløber havnene - en afgift som varierer, alt efter hvor store emissioner de enkelte skibe har. Norge vil tilbageføre provenuet fra den $\mathrm{NO}_{\mathrm{X}}$-afgift, som er indført, med henblik på at få energiintensive virksomheder til at implementere forureningsbegrænsende tiltag.

5. Göteborg-protokollen vil fungere mere effektivt, hvis også Rusland underskriver protokollen. Dette gælder i særdeleshed set fra en nordisk synsvinkel. I takt med forbedringen af den russiske økonomi stiger også de russiske luftemissioner. Et enkelt hot-spot i Murmansk tegner sig for en $\mathrm{SO}_{2}$-udledning på størrelse med det samlede udslip fra Norge og Finland. Göteborg-protokollen er baseret på emissionslofter for det nord-vestlige Rusland, inklusiv Skt. Petersborg, Kaliningrad og Murmansk. De forventede fordele, som kunne opnås ved begrænsninger af emissioner her, er derfor endnu ikke blevet materialiserede, i modsætning til de forbedringer som er opnået i de lande, som har underskrevet protokollen. I den forbindelse er det en smule paradoksalt, at det tidligere Sovjetunionen var en af initiativtagerne bag 'Convention of Long-Range Transport of Air Pollutants' (CLRTAP).

6. Nye videnskabelige resultater peger på, at det nuværende niveau for emissioner af fine partikler medfører betydelige reduktioner $\mathrm{i}$ de eksponeredes levetid. En revideret protokol bør derfor balancere lofter for emissioner af sekundære partikler med nye lofter for emissioner af primære partikler $\left(\mathrm{PM}_{2.5}\right)$ for at maksimere fordelene ved emissionsbegrænsninger. Dataindsamling og overvågning af naturlige og organiske dele af partikelmassen kunne systematiseres og forbedres som et led i en revideret protokol. RAINS-GAINS vil her være værdifuld, som et beslutningsstøtteværktøj i arbejdet med at revidere og ændre protokollen; især hvis flere meteorologiske år indarbejdes i modelbasen. Det anbefales desuden at undersøge signifikansen af non-linearitet i atmosfærisk kemi og transport i forhold til antagelserne i RAINS-GAINS for at afdække de forventede resultater for protokol-underskriverne.

7. EU's 'Clean Air for Europe' program peger på, at sundhedsfordelene ved en begrænsning af luftemissionerne ser ud til at udgøre de væsentligste monetære fordele. Modelresultater indikerer, at de monetære fordele ser ud til at være i størrelsesordenen $€ 7-15 / \mathrm{kg} \mathrm{NO}_{\mathrm{X}} \mathrm{i}$ de 
tættest befolkede dele af Norden. I en revideret protokol, som primært baseres på de sundhedsmæssige fordele ved emissionsreduktioner, kan der forventes endnu større fordele i de mere tæt befolkede dele af Europa. Fx kan centraleuropæiske lande forventes at have væsentligt større benefit-cost-rater end de nordiske lande. Disse omstændigheder vil kunne lette vedtagelse og implementering af en revideret protokol. Omvendt er det dog vigtigt ikke at glemme de bekymringer om tilstanden i økosystemer (søer og skove), som førte til det nordiske initiativ indenfor CLRTAP for mere end 20 år siden. Metoder til at integrere kritiske grænser for økosystemer bør derfor integreres bedre i protokollens modeller.

8. Luftemissionsreduktioner fra konventionelle emissionstyper giver, som en sideeffekt, visse fordele indenfor klimapolitkkens kontekst, hvor det primære fokus er at begrænse anvendelsen af fossile brændsler. I de kommende årtier forventes signifikante forandringer i energi- og transportsystemerne iværksat for ikke at få klimaforandringer større end $2^{\circ}$ temperaturændring. Visse alternative energikilder - fx sol-, vind- og bølgekraft - vil begrænse luftemissionerne, mens andre fornyelige energikilder sandsynligvis vil øge emissionerne; det gælder fx biobrændsler (herunder affaldsforbrænding). Tættere koordination i de parallelle forhandlinger under CLRTAP og UNFCCC kan derfor anbefales. 